This item was submitted to Loughborough's Research Repository by the author.

Items in Figshare are protected by copyright, with all rights reserved, unless otherwise indicated.

\title{
Contagion from the crises in the Euro-zone: where, when and why?
}

PLEASE CITE THE PUBLISHED VERSION

https://doi.org/10.1080/1351847X.2019.1589552

PUBLISHER

(c) Taylor and Francis

VERSION

AM (Accepted Manuscript)

PUBLISHER STATEMENT

This is an Accepted Manuscript of an article published by Taylor \& Francis in The European Journal of Finance on 14 March 2019, available online: http://www.tandfonline.com/10.1080/1351847X.2019.1589552.

\section{LICENCE}

CC BY-NC-ND 4.0

\section{REPOSITORY RECORD}

Pentecost, Eric, Wenti Du, Graham Bird, and Thomas Willett. 2019. "Contagion from the Crises in the Eurozone: Where, When and Why?". Loughborough University. https://hdl.handle.net/2134/37480. 


\section{Contagion from the Crises in the Euro-zone: Where, When and Why?}

Eric J. Pentecost**** Wenti Du***** Graham Bird*** and Thomas Willett***

* School of Business \& Economics, Loughborough University, Loughborough, Leicestershire, LE11 3TU, UK. Email: e.j.pentecost@lboro.ac.uk

** Global Business Program, Akita International University, Yuwa, Akita City, 010-1292, Japan. Email:wdu@aiu.ac.jp

*** Division of Politics and Economics, Claremont Graduate University, 150 East $10^{\text {th }}$ Street, Claremont, CA91711, USA.Email: Graham.Bird@cgu.edu or Tom.Willett@cgu.edu 


\title{
Contagion from the Crises in the Euro-zone: Where, When and Why?
}

\begin{abstract}
The prevalence of contagion between the Euro-zone countries and other European countries since the Greek crisis of 2009 is now well-known, but the factors that influence the pattern of this contagion are not well understood. We investigate this question both within Europe and beyond to the USA and Japan, using an asymmetric M-GARCH model that focuses on extreme values of the risk premia on government bonds. We compare these extreme values with news of major events and find that they are highly correlated. We find a different pattern of contagion emanating from Ireland compared to the other crisis countries of Greece, Italy, Portugal and Spain. We also examine the factors that have made countries vulnerable to contagion and find that financial factors are more important than trade ones. However, intra-Euro-zone trade has also been a significant factor between the major Euro-zone economies. There is little evidence that global factors affect contagion between EU member states, but some evidence that nominal exchange rate movements offer a degree of insulation from contagion for the non-Euro zone states.
\end{abstract}

JEL Codes: G01, G15, C58

Keywords: Contagion, Extreme values, M-eGARCH models, Quantile regression 


\section{Introduction}

The phenomenon of financial market contagion, whereby a crisis in one country may spread to affect others, has attracted attention in the context of a series of crises that have occurred since the early 1990s. Particularly noteworthy have been the East Asian financial crisis in 1997/98, where the crisis in Thailand spilled over and affected many regional neighbours, as well as reaching both Russia and Argentina, and the Euro crisis that erupted in 2009. While the literature has sometimes sought to distinguish between various types of contagion including wake-up call contagion, shift contagion and pure contagion unrelated to fundamentals, mixed findings have been reported relating to both the pattern and extent of contagion. ${ }^{1}$

In the context of the Euro-zone crisis many studies have adopted conventional correlation techniques as a way of identifying contagion and have used continuous high frequency data to focus on the co-movement in government bond yields. The results have again been mixed and are not directly comparable because of differences in the details of the estimation techniques used and countries and time periods covered. For example, while not offering any tests of statistical significance, Missio and Watka (2011), present evidence to suggest the risk premia in Portugal, Spain, Italy and Belgium have been correlated with those in Greece. Muratori (2014) also discovers similar evidence of contagion. In contrast, using a time varying spillover regime switching model and a time varying conditional copula model, Philippas and Siriopoulos (2013) find no significant contagion effect from Greece on Portugal, Italy and Spain. Meanwhile, Pragidis et al. (2015) find that in many cases the correlation between bond yields in Greece and elsewhere actually decreased after the eruption of the Greek crisis in 2009. Statistical correlation

\footnotetext{
${ }^{1}$ For an analysis of the various types of contagion see Forbes and Rigobon (2002), Forbes (2012), Metiu (2012), Ludwig (2014), Mink and de Haan (2013), and Cronin et al. (2016).
} 
techniques for examining contagion, have included dynamic conditional correlation (Engle, 2002; Chiang et al., 2007), asymmetric generalized conditional correlations (Cappiello et al., 2006), and copula functions (Kenourgiois et al., 2011; Joneau and Rockinger, 2006).

An often preferred method of measuring contagion is based on selecting extreme negative events and examining their effects, rather than using all observations which combine small and large changes in the risk premium. In the modern literature on contagion, the extreme negative events have usually been located in the Euro-zone or more specifically in Greece. Using this approach, Forbes (2012), for example, discovers that contagion between stock markets is stronger in the Euro-zone than in her full sample of countries. Using a similar approach, Aizenman et al. (2012) examine the impact of the Euro-zone crisis on developing countries, while Stracca (2015) investigates the effects of the crisis in 2010-12 on a wide range of both advanced OECD countries and non-OECD emerging and developing economies. He discovers that the crisis contributed to a rise in global risk aversion and a fall in equity returns, mainly in the financial sector, with the impact on government bond yields being much more muted.

In this paper we also adopt an approach based on extreme negative events in terms of government bond yields, but we confirm our identification of extreme events by testing the correlation between the extreme values of bond yields and 'news' events reported in the media that we assess as being particularly negative. We find them to be highly correlated. In addition we make three contributions to the existing literature. First, many of the published studies have been relatively narrow in their span and scope, often because they were undertaken while the crisis was still in progress. In contrast, we examine the geographical extent of contagion between eight Euro-zone member states, a further six European states as well as the USA and Japan. Although all are advanced economies, they have varying degrees of capital market integration 
and very different exchange rate regimes, which may have a bearing on the direction and extent of contagion from the EU Crisis countries; Portugal, Ireland, Italy, Greece and Spain (PIIGS). By using a system estimation technique we are also able to consider the potentially difficult issue of reverse or two-way causality between the PIIGS.

Second, given the duration of the Euro-zone crisis we are able to examine the time-varying pattern of contagion. We look at different sub-periods, when the crisis has possessed different degrees of intensity, and use dynamic conditional correlations (see, for example, Aielli, 2013) at both daily and weekly frequencies to examine the time-varying nature of contagion.

Third, observing that some countries are subject to greater contagion than others leads to the question of why this is. We therefore estimate empirically what factors affect vulnerability to contagion from an extreme negative event elsewhere. Whilst acknowledging the possible links between them, Forbes (2012) emphasizes the importance of trade, banks, portfolio investment and wake up calls. She finds evidence to suggest that, while all these channels have been significant, wake up calls have been the least important and leverage in the domestic banking sector has been the most important. In a related exercise based on the Euro crisis in 2010-12, Stracca (2015) finds that the strength and direction of contagion depend on trade exposure to the Euro area, EU membership and whether the country's exchange rate is pegged to the euro. In this paper we examine the importance of trade intensity with the Euro-zone, the structure of the financial and banking sectors, the amount of fiscal space, and indicators of macroeconomic fundamentals. One main objective is to discern whether contagion occurs primarily through the financial or real sector of the economy. 
The paper is structured as follows. Section 2 outlines the methodology and the model used to test for contagion. As noted earlier, our main methodological approach uses extreme event analysis but we also supplement this by examining alternative approaches using GARCH and conditional probit models. Section 3 explains the data set used and Section 4 reports the results from the multivariate eGARCH model. Section 5 uses a conditional logistic model to examine the underlying macroeconomic factors that explain vulnerability to contagion. Section 6 offers a few concluding remarks and briefly explores the implications of our findings for policy.

\section{The Model and Methodology}

The contagion we explore is that emanating from Euro-zone long-bond government markets, linked directly to the debt crisis faced by many Euro-zone economies after 2008, but most especially Portugal, Ireland, Italy, Greece and Spain. To this end we focus on the sovereign risk premium, $\tau_{\mathrm{i}}$, defined as the difference between the 10-year bond yield of country $i$ less the German $(\bar{r})$ long-term bond yield measured in Euros, that is: $\tau_{\mathrm{it}} ? r_{\mathrm{it}} / \bar{r}_{\mathrm{t}}$.

Since asset returns are likely to exhibit volatility clustering, whereby the current level of volatility is positively related to its level in the immediately preceding periods, we model this using the M-GARCH class of models that can be written as

$$
\tau_{\text {it }} ? \delta_{0 \mathrm{i}}-\gamma_{\text {it }} \quad \text { where } \bar{F}_{0 \sigma_{c}}\left(0,5_{\mathrm{O}}\right)
$$

and where $\tau_{\text {it }}$ is a $\mathrm{n} \times 1$ vector of risk premia, $\delta_{0 \mathrm{i}}$ is a corresponding $\mathrm{n} \times 1$ vector of constants and the error term, $\gamma_{\text {it }}$, has a zero mean but time-varying variance, denoted by the variancecovariance matrix, $H_{t}$ which is of dimension $\mathrm{n} \times \mathrm{n}$. 
This basic specification, however, does not allow us to identify any specific cause of contagion. As contagion is something which goes beyond a normal level of interdependence, if we assume that $\delta_{0 \mathrm{i}}$ denotes the average level of interdependence between the set of risk premia, then contagion must be additional to this ${ }^{2}$. In the Euro-zone crisis we know that crises manifested themselves first in Greece, but then Ireland, Italy, Portugal and Spain became additional, although not necessarily wholly independent, sources of risk, and hence potential sources of contagion at different times over the sample. To capture these additional potential sources of contagion we include the extreme values of the measured risk premium from each of the crisis countries, $\tau_{\mathrm{jt}}^{\mathrm{exv}}$, as additional explanatory variables to (1), to give:

$$
\tau_{\mathrm{it}} ? \delta_{0 \mathrm{i}}-\sum_{\mathrm{j} ? 1}^{5} \delta_{\mathrm{j}} \tau_{\mathrm{jt}}^{\mathrm{exv}}-\gamma_{\mathrm{it}}
$$

where the subscript $\mathrm{j}$ denotes the five crisis countries, and $\tau_{\mathrm{jt}}^{\mathrm{exv}}$ denotes the extreme values of the measured risk premium in each of the five crisis countries as measured by observations one standard deviation above the mean. At this stage we assume that the elements of $\tau_{\mathrm{jt}}^{\mathrm{exv}}$ are independent, although interactive terms can be included in the model. The coefficients $\delta_{\mathrm{j}} ?\left(\delta_{\mathrm{GR}}, \delta_{\mathrm{IR}}, \delta_{\mathrm{IT}}, \delta_{\mathrm{PO}}, \delta_{\mathrm{SP}}\right)$ measure the impact of a rise in the relevant risks in each of the crisis countries to a wider set of $\mathbf{i}$-country risk premia, where $\mathbf{i} \cong \mathbf{j}$ and $\mathbf{j} \subset \mathbf{i}$.

The sign of $\delta_{\mathrm{j}}$ is ambiguous. In the case of direct contagion $\delta_{\mathrm{j}}$ is expected to be positive as the additional risk spreads to other countries whose bonds are perceived as having similar risk

\footnotetext{
${ }^{2}$ Since the model is only estimated over the crisis period, the average level of risk is likely to be higher than in a non-crisis period and so the value of $\boldsymbol{\delta}_{\mathrm{0i}}$, is also likely to be a little higher. This, however, is not important to the argument here.
} 
characteristics to those of country $j$, and whose currencies are closely linked to the value of the euro. But the sign of $\delta_{\mathrm{j}}$ can also be negative if the country concerned (here referred to as the 'home' country) is deemed to be a safe haven. In this case, investors flee euro-denominated assets and purchase home country bonds. If this capital flow is sufficiently large it will raise the price of home countries' bonds and lower their yield, relative to those of German bonds, thus reducing the interest rate differential ${ }^{3}$. Unless Germany's interest rates for some reason fall by more, this will reduce the interest differential. In such cases the implication is that, in search of greater safety, more funds would be diverted to countries outside of the Euro-zone than to Germany itself.

In order to estimate the model we need to allow for the stylized fact that the basic GARCH model is symmetric and so therefore does not capture the observed asymmetry in financial returns data. Asymmetry implies that unexpected bad news (such as an increase in the risk premium) increases conditional volatility more than unexpected good news (such as decrease in risk premium), of similar magnitude. To capture this asymmetry there are a number of alternative GARCH models including, eGARCH (Nelson, 1991), GJR-GARCH (Glosen et al, 1993), APARCH (Ding et al, 1993), AGARCH, (Engle and Ng, 1993), TARCH (Zakorian, 1994) and NAGARCH (Higgins and Bera, 1992). In this paper we follow a multivariate asymmetric GARCH approach, selecting the model which gives the best fit to the data, which is usually the eGARCH model, where the multivariate conditional variance is specified as:

$$
\ln h_{i t} ? c_{i}-b_{i} \ln h_{i t / 1}-a_{i} f\left(z_{i t / 1}\right)
$$

\footnotetext{
${ }^{3}$ This assumes that flows out of the crises countries into Germany do not have a significant effect on German
} interest rates, which are used to capture global capital market factors. 
where $f\left(z_{i, t / 1}\right)$ ? * $z_{i, t / 1} \mid / E\left(\left|z_{i, t / 1}\right|\right)-l_{i} z_{i, t / 1}+$ and where $z_{i, t} ? \gamma_{i t} / h_{i, t}^{/ 1 / 2}$, is the standardised error. Equation (3) shows that the variance depends on a constant, $c_{i}$; the persistence of countryspecific volatility, as measured by $b_{i}$; and on a series of "news terms" captured by the parameters, $a_{i}$. This says that the conditonal heteroscadasticity is an asymmetic function of past standardised innovations, $z_{i, t / 1}$. The term $* z_{i, t / 1} \mid / E\left(\left|z_{i, t / 1}\right|\right)+$ measures the magnitude of past innovations, which is positive if $l_{i}$ ? 0 and the size of $z_{i, t / 1}$ is greater than its expected value. The term $l_{i}$ captures what is known as the leverage effect and it measures the sign of the effect of past innovations. If $\boldsymbol{l}_{i} \cong 0$ then $h_{i t}$ is rising by more than when $\iota_{i} ? 0$ and by less if $\iota_{i}>0$. Thus if $l_{i} \cong 0$ then bad news ( a rise in risk ) leads to a greater rise in the conditional volatility, but if $l_{i}>0$ then good news (a fall in a country's risk premia) means the conditional volatility rises by less than in the symmetric case.

Under the conditional normality assumption the log-likelihood function $L(\Sigma)$, for the multivariate eGARCH model is written as:

$$
L(\Sigma) ?\left[/ \frac{1}{2}(k n) * \ln \left(2 \rho+/ \frac{1}{2} \sum_{t ? 1}^{n} * \ln \left|H_{t}\right|-\gamma_{t}^{\prime} H_{t}^{\prime 1} \gamma_{t} t_{\rceil}\right]\right.
$$

where $\Sigma$ is the parameter vector to be estimated, $k$ is the number of equations, $n$ is the number of observations, $\gamma_{t}^{\prime}$ is the vector of innovations at time $\mathrm{t}$ and $H_{t}$ is the time-varying conditional variance -covariance matrix with diagonal elements given by equation (3).

As a robustness check on the results we also make use of the quantile method, (see Koenker and Hallock, 2001) where the conditional median function for the risk premium, $Q_{q}(\tau \mid X)$, given 
$q \in(0,1)$ splits the sample data into proportions $q$ below and $(1-q)$ above the median. The quantile regression method then gives asymmetric penalties $(1 / q)\left|e_{i}\right|$ for over-prediction and $q\left|e_{i}\right|$ for under-prediction where $\left|e_{i}\right|$ is the series for the absolute residual. The quantile regression estimator minimizes the objective function:

$$
Q\left(\delta_{q}\right) ? \sum_{i: \tau_{i} \geq X_{q}^{\prime} \delta}^{n} q\left|\tau_{i} / X_{j}^{\prime} \delta_{q}\right|-\sum_{i: \tau_{i} \leq X_{q}^{\prime} \delta}^{n}(1 / q)\left|\tau_{i} / X_{j}^{\prime} \delta_{q}\right|
$$

where $Q$ is the number of partitions of the data set, in this case 4 , for quartiles, $X_{j}$ is the $\mathrm{n} \times 5$ matrix of extreme values of the risk premium, where $j \subset i$, and $\delta_{q}$ the coefficient estimates. The quantile regression estimator is asymptotically normally distributed and estimated using linear programming methods.

\section{The Data}

Matching average daily 10-year sovereign bond yields were taken from investing.com and average daily spot exchange rate data from the ECB website for 18 countries from $1^{\text {st }}$ October 2009 until $12^{\text {th }}$ August $2016^{4}$ which, allowing for weekends and bank holidays, gives 1,746 observations. There are the five crisis countries; Portugal, Ireland, Italy, Greece and Spain, plus four other Euro-zone countries Belgium, France, Germany and the Netherlands. There are three central and eastern European countries which have effectively a pegged rate with the Euro - The Czech Republic, Hungary and Poland - and then five other non-Euro countries - three in Europe - Sweden, Switzerland and the UK and two other's Japan and the USA. Since we are not strictly

\footnotetext{
${ }^{4} 1$ st October 2009 is selected as the start date because it marked the beginning of the permanent deviation of Greek rates from German rates. From the start of the Euro until 2009 the average deviation between Greek and German 10 -year bond rates was about $0.26 \%$. In October 2009 the deviation was about $1.36 \%$ as the sharp upward trend in Greek rates began, which we take to mark the beginning of the first Greek crisis.
} 
testing for market efficiency the trading time differences between the European markets hours is not crucial, as we are using average daily data, although we do not include the USA and Japan in the daily analysis, but only in the weekly analysis, which is used to see if there is a different pattern of contagion over a slightly longer time horizon.

The interest rate differential (or risk premium) for Euro-zone members is the difference between the home country bond yield and the German yield. For consistency, all country risk premia are computed with reference to the German long-bond yield, as the contagion we wish to measure refers to the Euro-zone. For countries that are not members of the Euro-zone, an alternative measure was calculated allowing for expected changes in the spot exchange rate. The 'home' interest differential for these countries is defined as $\tau_{i t} ?\left(r_{i t} / x_{i t}\right) / \bar{r}_{t}$ where $r_{i t}$ is the long-term sovereign bond yield of the home country $i$ in period $t$ in its domestic currency and $x_{i t}$ is the expected bilateral depreciation of the home currency against the euro ${ }^{5}$.

To compute the extreme events for Portugal, Ireland, Italy, Greece and Spain, we defined extreme values of the risk premium as values that were greater than one standard deviation from the mean ${ }^{6}$. The $\tau_{\mathrm{jt}}^{\mathrm{exv}}$ series were computed by the formula: $\tau_{j t}^{e x v} ? \tau_{j t} \times D U M_{j}$ where $D U M_{j}$ is a country-specific $(0,1)$ dummy which takes the value of unity when the country risk premium exceeds one standard deviation of its mean and zero otherwise. The $\tau_{\mathrm{jt}}^{\mathrm{exv}}$ series were then compared to actual news events (see Bird et al., 2017b) over the core period of the sample. There are about eighty identified important news events (see Table 5 of the online Appendix for

\footnotetext{
${ }^{5}$ We proxy changes in the expected exchange rate in two ways: as either static (no expected change) or perfect foresight (instantly and fully adjusted). If daily exchange rate expectations are constant then $x_{\mathrm{t}}=0$, whereas in the case of perfect foresight expectations $x_{\mathrm{t}}=\left(\left(e_{\mathrm{t}+1} / e_{\mathrm{t}}\right)-1\right) \times 100$, where $e_{t}$ is the spot exchange rate.

${ }^{6}$ We also experimented with extreme values of two standard deviations from the mean, but this left us with very few values.
} 
details) that are likely to affect all the crisis countries, and which had an extremely close positive association with our extreme values of the risk premia. Table 1 shows the results of a simple correlation exercise in which the correlation coefficients between the actual events and the $\tau_{\mathrm{jt}}^{\mathrm{ex}}$ series for each of the five crisis countries were all equal to 0.99 and highly significant. Thus the $\tau_{\mathrm{jt}}^{\mathrm{exv}}$ series provide very good proxies for news events and the potential source for contagion ${ }^{7}$.

\section{Insert Table 1 near here}

As Table 1 also shows, however, the extreme values of the interest differential (or news) in each of the five crisis countries are not independent, raising the issue of potential multicollinearity if the extreme values of all five countries are included in the regression. The extreme values of the interest differential in Greece are highly correlated with the corresponding extreme values of the interest rate differentials in Italy, Portugal and Spain. Given this high degree of collinearity, from a statistical point of view, it is not unreasonable to use extreme events in Greece as representative of extreme events in all four of the crisis countries, other than Ireland.

Ireland, however, has a different profile from the other crisis countries reflecting the different nature and timing of the crisis there. Whereas the Greek crisis was essentially a public debt one, in Ireland the crisis originated in the private sector, and was reflected in a housing boom. This morphed into a fiscal crisis, however, when the government undertook a substantial bailout. Chart 1 shows the Greek and Irish daily interest rates over the whole sample. Interest rates in Ireland exceeded $6 \%$ between $7^{\text {th }}$ September 2010 and $4^{\text {th }}$ September 2012, a period of almost exactly two years corresponding closely with the period of the Irish crisis. Over the same period,

\footnotetext{
${ }^{7} \mathrm{~A}(0,1)$ dummy variable was created, in which the one's denoted each individual news event. This series was then correlated with each of the five the countries series of values of their extreme risk premium. Table 1 reports the simple correlation coefficients from this exercise.
} 
interest rates in Greece varied from $11.8 \%$ to $21.87 \%$. Thus, during the period of the crisis in Ireland, the risk premium in Greece was more than three times higher, although the peak of the Irish crisis, $12^{\text {th }}$ July 2011, preceded that of the first Greek crisis, on $8^{\text {th }}$ March 2012, by about eight months. The crisis in Ireland appears to have been less pronounced and shorter lived than the crisis in Greece. We therefore include Ireland as a potentially separate source of contagion from Greece in some of the estimated regression models and a potential source of contagion to Greece.

\section{The M-eGARCH and quantile regression results}

The model is estimated with data of both daily and weekly frequencies, but also with static and perfect foresight exchange rate expectations for the non-Euro area economies, using both asymmetric M-GARCH and quantile regression methods as a check on the robustness of the results. Tables $2 \mathrm{~A}$ and $2 \mathrm{~B}$ provide detailed results for the static exchange rate expectations case, with the very similar perfect foresight results reported in Tables $6 \mathrm{~A}$ and $6 \mathrm{~B}$ in the online Appendix.

Insert Tables $2 A$ and $2 B$ near here

Tables $2 \mathrm{~A}$ and $2 \mathrm{~B}$ show the daily frequency results for the $\mathrm{M}-\mathrm{eGARCH}$ and quantile regression models respectively, for all 14 European countries with constant exchange rate expectations. The first column in both Table 2A and 2B shows the "average" risk premium of the home country over Germany; in almost every case it is positive and significant. The relatively low values of $\delta_{0}$ for France and Netherlands reflect a very close alignment with Germany, whereas the high value for Greece shows a higher equilibrium interest rate differential with Germany. The single 
exception is Switzerland which has a negative sign, indicating that on average Swiss long-term interest rates on bonds were lower than in Germany.

The first finding from the regression analysis is the interdependence between the five crisis countries, as shown by the predominantly positive and significant $\delta_{1}$ coefficients in the top five rows of Tables $2 \mathrm{~A}$ and $2 \mathrm{~B}$. In other words there is positive two-way contagion between Greece and Italy, Greece and Portugal, Italy and Portugal and Italy and Spain. This most likely reflects the common very high average debt to GDP ratios over the sample - Greece (155\%), Portugal $(110.9 \%)$ and Italy $(127 \%)$ - as well as location juxtaposition in southern Europe. On the other hand, there are also important independencies: the risk premiums of Spain and Ireland and of Greece and Spain show no significant dependency in Table 2B, although from Table 2A it seems that Ireland may export contagion to Spain and Spain to Greece. It is also the case that Ireland may spread contagion to Greece, but not vice-versa and in the quantile results Ireland may even be a safe haven for Greece ${ }^{8}$.

Secondly, of the three core Euro-zone economies the Netherlands is more immune from contagion from all other countries than either Belgium or France. This reflects the close relationship between the Netherlands and Germany and the correspondingly low debt ratio (62\%), compared to both France (86.1\%) and Belgium (101.8\%). Even so the Netherlands does seem to import some contagion from Ireland and Italy, and perhaps Portugal, but in every case the $\delta_{1}$ coefficient is very small and never larger than 0.07 .

Without exception the three central and eastern European countries (CEECs) have all been subject to rising risk premiums as a result of high premia in the five crisis countries, although

\footnotetext{
${ }^{8}$ See Guidolin and Pedio (2017) for an alternative analysis of contagion that also discusses 'flight to quality' effects.
} 
they are relatively small economies, which are outside of the Euro-zone, and so not as financially integrated as the members. In most cases the $\delta_{1}$ coefficient for Hungary is larger than those for Poland and the Czech Republic, again possibility reflecting its higher average debt ratio, which at $76.6 \%$ is more similar to that of Spain than to Poland (51.5\%) or the Czech Republic (38\%). Finally, Tables 2A and 2B show that the final three countries - Sweden, Switzerland and the UK - have predominantly negative $\delta_{1}$ coefficients so they face a fall in their risk premiums when the risk premia of the PIIGS rises. They therefore in general exhibit safe haven properties, although there is some evidence from the daily data that the UK imported contagion from Greece, from the quantile results. This is difficult to explain, although in the M-eGARCH results this positive $\delta_{1}$ coefficient is statistically insignificant, suggesting that this effect is not very important.

An advantage of the M-eGARCH model is that dynamic, conditional correlations are produced which illustrate the daily dynamics in the risk premium. In addition the variance model in Table 2A shows the importance of the leverage effect, characteristic of eGARCH models. With just three exceptions - Greece, Ireland and Portugal - the leverage parameter ...is highly significant and positive; suggesting that bad news (a rise in risk) leads to a greater rise in the conditional volatility in the risk premium, than when there is good news. In the case of Greece, Portugal and Ireland (in the daily data only) the persistence effects dominate the asymmetric news effects with large and highly significant coefficients on the $b$ 's. This may reflect the relative longevity of the crises in Greece and Portugal.

The daily, dynamic conditional correlations between the risk premia and the daily volatility in contagion are shown in Figure 2 (in the on-line appendix). The horizontal line through zero reflects no contagion, with the fluctuations around it suggesting days of high positive correlation 
(contagion) and other days of negative correlation (safe haven effects). Without exception these daily time-varying correlations are highly volatile, with sharp movements likely reflecting small market developments or investor mood swings. In addition to the daily volatility, the amplitude of the time paths differ. For example, the amplitude of the daily fluctuations is largest for the PIIGS against the safe haven countries, the UK, Switzerland and Sweden and Belgium. The key point is that contagion is time dependent and although the $\delta_{1}$ 's shown in Tables $2 \mathrm{~A}$ and $2 \mathrm{~B}$ report the average correlations over the sample, the charts show that the daily volatility is in general important and much more complex.

\section{Insert Tables 3A and 3B near here}

The weekly frequency results are shown in Tables $3 \mathrm{~A}$ and $3 \mathrm{~B}$ and serve not only as robustness checks on the daily results, but also extend the sample to include the USA and Japan ${ }^{9}$. The sign pattern is not significantly different to the daily data, with the core Euro-zone countries and CEECs all experiencing contagion from the PIIGS, and a predominance of safe haven effects for Switzerland, Sweden and the UK. The new results centre on the USA and Japan. For Japan $\delta_{0}$ is negative, because like Switzerland, Japanese long bond rates are below those in Germany. Although results for $\delta_{1}$ appear inconsistent, the quantile regression model shows a poor fit, and little weight should therefore be put on these specific results. In Table 3A significant safe haven effects are posted for Portugal and Italy, whereas in Table 3B the safe haven effects are for Greece and Ireland. The explanation probably lies in the fact that Japanese long bond rates have been very low for the whole of the sample period and was negative after February 2016. For the USA there are not only significant safe haven effects for Ireland, but also for Spain and Portugal

\footnotetext{
${ }^{9}$ The very similar results with perfect foresight exchange rate expectations are presented in Tables 7A and 7B in the on-line appendix.
} 
in the M-eGARCH results. The weekly dynamic conditional correlations shown in Figure 3, in the on-line Appendix, indicate persistent safe haven effects for Ireland-USA. In addition, there is period of sustained contagion for several country pairs from early-2013 until mid-2014, soon after between Draghi's announcement to save the Euro and the rise of the Syriza party in Greece. The best examples are perhaps Italy-France, Portugal-Italy and Ireland with Spain, Portugal and Italy, contagion which may in part reflect the cost of saving the Euro.

We undertook two further experiments with this data set. First, we dropped Portugal, Spain and Italy from the crisis country group as sources of contagion, because the extreme values of the interest rate differentials between Greece, Portugal, Spain and Italy are all highly correlated - see Table 1 - and so by excluding the highly correlated source countries we hope to improve the efficiency of the estimates by reducing the degree of multicollinearity. Second, we split the sample at $18^{\text {th }}$ September 2014, to see if the pattern of contagion was any different in the Second Greek crisis to that in the first.

When we focus on extreme negative events (or news) only in Greece and Ireland, the daily data set shows Greece and Ireland are both significant sources of contagion to all Euro-zone and CEECs, whilst Switzerland, the UK and Sweden are safe havens (see on-line appendix, Tables $8 \mathrm{~A}$ and $8 \mathrm{~B}$ ). On the weekly data the quantile regression estimates (see on-line appendix, Tables 9A and 9B show exactly the same results, but the asymmetric GARCH model suggests that Portugal, Italy and France are safe havens for Greece. Both Greece and Portugal have very strong persistence effects from the variance model and no asymmetric news effects. As expected the broad pattern is strongly confirmed for all five PIIGS. 
Following Bird et al. (2017a) the sample is split in two to reflect the two Greek crises and the results given in Tables 10A and 10B in the in-line appendix. In the first Greek crisis period, from $1^{\text {st }}$ October 2009 until $18^{\text {th }}$ September 2014, Ireland was a safe haven for Greek investors (together with the US, Sweden, Switzerland and the UK). Hungary was the only country not significantly affected by the crisis. Spain, Portugal and Italy faced most contagion, although Japan was also significantly, but more moderately, affected. In the second Greek crisis period, from $19^{\text {th }}$ September 2014 until $12^{\text {th }}$ August 2016, the contagion effects are generally smaller, although still significant and as widespread as previously ${ }^{10}$. However, the safe haven effects are much smaller, with only the USA experiencing a strongly significant one. Notably, in this subperiod Ireland is affected by contagion from Greece and is not a safe haven as it was during the first Greek crisis.

The effects of extreme negative events in Ireland are also very different between the two subperiods. In the period of the first Greek crisis there is also contagion from Ireland, with Belgium perhaps the most affected of the Euro-zone countries, followed by Greece itself. However, there is no significant contagion to the Euro-zone from Ireland during the second Greek crisis period essentially because the Irish crisis was over before the second Greek crisis began. Contagion from the Irish crisis was shorter-lived than that from Greece.

Analyses of the effects of the crisis in the Euro-zone on non-European countries are an interesting and novel feature of this paper. In terms of impact effects over the whole sample, the

\footnotetext{
${ }^{10}$ The statement by Mario Draghi in July 2012 that the ECB would do "whatever it takes" to save the Euro seemed to bring the acute phase of the first crisis to an end. In April 2013 the Greek parliament approved further economic reforms and in November Moody's upgraded Greece's crediting rating as did Fitch in May 2014. However the growing popularity of the anti-austerity Syriza party sowed the seeds for a second crisis. This can be timed from mid-September 2014 when the leader of the Syriza party announced that he would bring austerity to an end. The crisis peaked in July 2015 but abated as tensions between Greece and its creditors eased and the Greek parliament approved new austerity measures as a precursor to further bailout funds. Detailed statistical support for the identification and timing of the two crises is provided by Bird et al. (2017a).
} 
USA acted as a safe haven in the case of extreme negative events in Ireland and Spain, but not so much in the case of Greece. However not all non-European countries reveal the same pattern. Thus, while Japan acted as a safe haven when there were extreme negative events in Ireland, it experienced direct contagion from extreme negative events in Greece. The pattern alters when a distinction is made between the first and second crises in Greece since both safe haven and contagion effects were more muted in the case of the second crisis.

\section{Factors affecting vulnerability to contagion}

Having established distinct patterns of contagion from the Greek and Irish crises, we now try and identify the factors that affect other countries' vulnerability to contagion. What is it that makes a country more or less vulnerable to contagion from an extreme negative effect in another country?

Conceptually we can distinguish two mechanisms. The first operates via effects on trade and capital flows. The second is via expectations; events in one country may directly affect expectations about other countries and hence the pricing of their financial assets. Thus, for example, although the trade effects may operate fairly slowly, expectations of these effects could affect asset prices quickly. Asset prices could thus adjust quickly even in the absence of capital flows, although it is likely that prices would be affected both through expectations effects and through capital flows themselves. For example, with an increase in risk premium risk-neutral investors would not adjust their portfolios assuming that they felt that the increase in the risk premium was sufficient to accurately reflect the increased risk, while more risk-averse investors 
would pull out. Given these considerations we think it best to think of the factors we investigate as indicators of market perception of vulnerability.

We include two measures of trade openness; first, a country's total trade relative to its GDP, as used by Forbes (2012), and second, a country's trade with Euro-zone countries (relative to GDP). Our expectation is that any one individual country is more likely to encounter contagion from a crisis in the Euro-zone when it trades relatively heavily with the source country or the other countries that are affected. Crises tend to be internationally transmitted, since a decline in national income in one country leads to a fall in its imports and therefore a fall in other countries' exports to that country. For countries that do not belong to the Euro-zone and have a flexible exchange rate there is another route through which trade linkages may operate. A fall in the value of the Euro, for example, will give Euro-zone exporters a competitive advantage in nonEuro zone markets while exporters to the Euro-zone from outside will be disadvantaged by any appreciation in their exchange rate vis-a-vis the Euro. This is likely to give rise to reduced exports sales depending on the value of key foreign trade price elasticities. The capacity for the exchange rate to move against the Euro also means that expectations may be important, as we have already discussed.

In addition to the trade variables, there may be a number of financial linkages by which an extreme negative event in one country affects others. Financial weakness is likely to make a country particularly vulnerable to contagion effects from elsewhere, whereas financial strength may be more likely to induce a safe haven effect. We include three measures of financial vulnerability, reflecting the soundness of the banking system, the stability of the public finances and global factors, such as the exchange rates and changes in US interest rates. 
We use the capital-to-assets ratio of domestic banks as an indicator of the general safety or fragility of the banking system, this is similar to Forbes' (2012) banking exposure variable (measured as gross banking assets plus liabilities). In the Euro-zone crises the size of public sector debt outstanding is also likely to be important in contributing to vulnerability. This may directly influence market confidence but will also affect fiscal space and therefore a government's ability to finance fiscal deficits and to neutralize the macroeconomic impact of crises elsewhere. Like Forbes (2012) we also include the change in US interest rate as a way of capturing any transmission effect through US capital markets. If the Euro-crisis is predominantly a European, as opposed to a world-wide phenomenon, we would expect this variable to be insignificant. In addition we also include the depreciation of the Euro against non-Euro zone currencies to try to capture the extent to which nominal exchange rates served to limit non-Euro zone countries' vulnerability to contagion.

The extreme values of the risk premium were converted into a series, $y_{j t}$, of $(0,1)$ dummies for each of the five crisis countries, which were then stacked. This enables us to estimate a panel, conditional logistic model, with fixed effects, which can be represented as:

$$
P\left(y_{j t} ? 1\right) ? \frac{e^{\eta_{1}-\delta x_{i t}}}{1-e^{\eta_{t}-\delta^{\prime} x_{i t}}}
$$

where $e$ is the base of natural logarithms, $\eta_{i}$ denotes the country fixed effects and the vector of fundamentals, $x_{i t}$, includes both the real side economic variables and financial variables, listed in the notes to Table 4 .

Insert Table 4 near here 
Table 4 presents the results from five specifications of the estimated model. The main findings are as follows. First, the change in the US interest rate had no significant effect on the vulnerability to contagion in the sample countries. Although the USA was a safe haven at the time of the Greek crisis, it played no significant role in the transmission of the crisis back to other EU countries. The exchange rate between the US dollar and the euro may have played a role in this but the effect was statistically insignificant. An appreciation in the Euro had no significant effect on the probability of an extreme negative event occurring. The positive sign on the exchange rate coefficient suggests, however, that euro depreciation would tend to decrease the probability of an increase in risk premia. This result is consistent with the findings of Obstfeld et al (2017) who find that exchange rate regimes do matter and that countries with fixed rates (or currency boards) are more strongly affected by international financial shocks as they have little autonomy over the design of monetary policy. This is also confirmation of our analysis of contagion which shows that the greater is the fixity of the exchange rate between economies the greater is contagion.

Second, both measures of openness to international trade have positive signs, indicating that the probability of an extreme negative event is marginally higher for a country that trades relatively heavily with other economies in the Euro zone. The measures are statistically significant in all specifications of the model although, as expected, the intra Euro-zone trade is slightly more important than global openness.

Third, the most robust finding relates to financial variables in the transmission process. The stock of public sector debt outstanding relative to GDP is positively signed and statistically significant in all specifications. This is not surprising given the large role that fiscal problems played in the crisis. A unit rise in the stock of public debt raises the probability of an extreme event by about 
2.5 to 3 per cent. This is the principal and most consistent channel of contagion through the bond markets in the financially integrated European Union. The importance of the banks' capital-toassets ratio, however, is not always significant. Its significance depends on the measure of openness used in the model. When intra Euro-zone trade is used then it is not significant, but if general global openness is used then it is statistically significant. This suggests that Euro-area banking sector assets are linked with intra-EU trade, but that there are distinct channels through which contagion may spread.

In Table 4, a downgrade of a country's debt by the rating agencies has by far the strongest effect, such that a downgrade leads to an increase in the probability of contagion of 100 per cent. This is in conflict with the strong form of the efficient markets view that most of the information influencing the decisions by the ratings agencies would have already been detected and priced by the market.

\section{Concluding Remarks}

Contagion from financial crises has been an increasingly common phenomenon in the world economy. Given its potential implications, it is important to understand the extent and pattern of contagion, not least in order to design policies that minimize its disruptive consequences. In this paper we have examined various dimensions of contagion in the context of the crisis in the Eurozone in the period 2009-2016.

We examine the effects of extreme negative events in a number of crisis countries and find that the contagion effects of these events have been particularly significant for other Euro-zone countries, although some countries (notably the crisis ones themselves) have been affected to a greater extent than others. However, not all crises have had similar consequences for contagion. 
In particular, there have been discernible differences between Ireland and the other crisis countries. Again, the policy implications are important. The policies pursued by Ireland seem to have been more successful both in terms of overcoming the crisis and in reducing its longer run effect, if not its impact effect, on other countries. This came at the price, however, of hitting the Irish public with the huge government debt resulting from the bailout of banks and investors. The balance of these costs and benefits including effects on moral hazard are now a major issue of debate.

Beyond this, we find that European countries that are currently outside the Euro-zone, but have a stated intention of joining it, have also been adversely affected by contagion.

We find that the extent and pattern of contagion changes over time. In most cases the contagion resulting from the second crisis in Greece that we identify as starting in September, 2014, was more muted. In part, this could be because other countries had devised methods of making themselves less vulnerable to it. Moreover, markets appear to have perceived that the risks of the Euro-zone collapsing had diminished. This would imply that the European institutions, in general and the ECB in particular, can influence the degree of contagion from extreme negative events in member countries (see, for example, Kosmidou, et al., 2018).

We examine the factors that affect the probability of an extreme negative event occurring and therefore also affect a country's vulnerability to contagion. Overall, we discover that financial variables are more significant than trade ones. We also discover modest evidence that a flexible exchange rate may serve to diminish contagion to some degree. In the ongoing debate about the relevance of the international macroeconomic policy trilemma, this provides some support for 
the claim that exchange rates continue to play a positive, but only weakly significant role in helping to partially insulate economies from external financial crises.

Other policy conclusions are at one and the same time both straightforward and complex. The straightforward part is that it is important to strengthen the banking and financial sectors and keep indebtedness below a level at which it is perceived as becoming unsustainable. The complex part is that this may mean circumstances arise where the use of expansionary fiscal policy to offset the spill-over effects from a financial crisis elsewhere in the domestic real economy may, at the same time, increase a country's vulnerability to contagion from future external financial crises. In addition to this, while one of the purposes of the Euro-zone is to encourage trade between member states, increasing intra Euro-zone trade makes countries more vulnerable to future contagion from crises elsewhere in the zone. Increasing Euro-zone trade therefore needs to be accompanied by policies designed to reduce the risks of financial crises and financial contagion. 


\section{References}

Aielli, G.P., 2013. Dynamic conditional correlation: on properties and estimation. Journal of Business and Economic Statistics, 31(3), 282-99.

Aizenman, J., Y. Jinjarak, M. Lee, M, and D. Park. 2012. Developing countries' financial vulnerability to the euro crisis: an event study of equity and bond markets. NBER Working Paper, No. 18028, National Bureau of Economic Research.

Bird, G., W. Du, E.J. Pentecost, and T. Willett. 2017a. Was it different the second time? An empirical analysis of contagion during the crises in Greece, 2009-2015, The World Economy, 40, 1-14.

Bird, G, Du, W. and Willett, T., 2017b. Behavioral finance and efficient markets: What does the Euro crisis tell us? Open Economies Review, 28 (2), 273-295.

Cappiello, L., R.F. Engle and K. Sheppard. 2006. Asymmetric Dynamics in the Correlations of Global Equity and Bond Returns. Journal of Financial Econometrics, 4, 537-572.

Chiang, T.C., B.N. Jeon, and H. Li. 2007. Dynamic correlation analysis of financial contagion: Evidence from Asian markets, Journal of International Money and Finance, 26, 1206-1228.

Cronin, D., T.J. Flavin and L. Sheenan.2016. Contagion in Euro-zone sovereign bond markets? The good, the bad and the ugly. Economics Letters, 143, 5-8.

Ding, Z., C.W. Granger and R.F. Engle. 1993. A long memory property of stock market returns and a new model. Journal of Empirical Finance, 1, 83-106.

Engle, R.F. 2002. Dynamic conditional correlation: a simple class of multivariate generalized autoregressive conditional heteroskedasticity models. Journal of Business and Economics Statistics 20, 339-350.

Engle, R.F. and V.K. Ng. 1993. Measuring and testing the impact of news on volatility. Journal of Finance, 48, 1769-78.

Forbes, K.J., 2012. The "Big C": Identifying and Mitigating Contagion in The Changing Policy Landscape, 2012 Jackson Hole Symposium hosted by the Federal Reserve Bank of Kansas City, 23-87.

Forbes, K.J. and Rigobon, R., 2002. No contagion, only interdependence: measuring stock market co-movements. Journal of Finance, 57, 2223-2261.

Jondeau, E. and M. Rockinger. 2006. The Copula-GARCH model of conditional dependencies: An international stock market application. Journal of International Money and Finance, 25, 827-853.

Glosten, L.R., R. Jagannathan, and D.E. Runkle. 1993. On the relationship between the expected value and the volatility of the nominal excess return on stocks. The Journal of Finance, 48(5), 1779-1801.

Guidolin, M. and M. Pedio. 2017. Identifying and measuring the contagion channels at work in the European financial crises. Journal of International Financial Markets, Institutions and Money. 48, 117-134. 
Higgins, M.L. and A.K. Bera. 1992. A class of nonlinear ARCH models. International Economic Review, 33, 137-58.

Kenourgios, D., A. Samitas and N. Paltalidis. 2011. Financial crises and stock market contagion in a multivariate time-varying asymmetric framework. Journal of International Financial Markets, Institutions and Money, 21 (1), 92-106.

Koenker, R. and K.F. Hallock. 2001. Quantile regression. Journal of Economic Perspectives, 15(4), 143-56.

Kosmidou, K., D. Kouserides, A. Ladas and C. Negkakis, 2018. Do institutions prevent contagion in financial markets? Evidence from the European debt crisis. European Journal of Finance DOI: 10.1080/1351847X.2018.1552171.

Ludwig, A., 2014. A unified approach to investigate pure and wake-up contagion: Evidence from the Eurozone's first financial crisis. Journal of International Money and Finance 48, 125-149.

Metiu, N., 2012. Sovereign risk contagion in the Euro-zone. Economics Letters 117, 35-38.

Mink, M. and J. de Haan. 2013. Contagion during the Greek sovereign debt crisis. Journal of International Money and Finance 34, 102-113.

Missio, S. and S. Watzka. 2011. Financial Contagion and the European Debt Crisis, CESifo Working paper, No. 3554

Muratori, U. 2014. Contagion in the Euro Area Sovereign Bond Market, Social Sciences, 4 (1), 66-82.

Nelson, D. 1991. Conditional heteroskedasticity in assets returns: a new approach,' Econometrica, 59, 347-370.

Obstfeld, M., J.D. Ostry and M.S. Qureshi. 2017. A Tie That Binds: Revisiting the Trilemma in Emerging Market Economics. IMF Working Paper, WP/17/130.

Philippas, D. and C. Siriopoulos. 2013. Putting the ' $\mathrm{C}$ ' into Crisis: Contagion, Correlations and Copulas on EMU Bond Markets. Journal of International Financial Markets, Institutions and Money, 27, 161-176.

Pragidis, I.C., G.P. Aielli, D. Chionis and P. Schizas. 2015. Contagion Effects During Financial Crisis: Evidence From the Greek Sovereign Bonds Market. Journal of Financial Stability $18,127-138$.

Stracca, L., 2015. Our currency, your problem? The global effects of the euro debt crisis. European Economic Review, 74, 1-13.

Zakoian, J., 1994. Threshold heteroscedastic models. Journal of Economic Dynamics and Control, 18, 931-55. 
Figure 1: Long-Term Bond Yields of Greece and Ireland from October 1, 2009, to August 12, 2016.

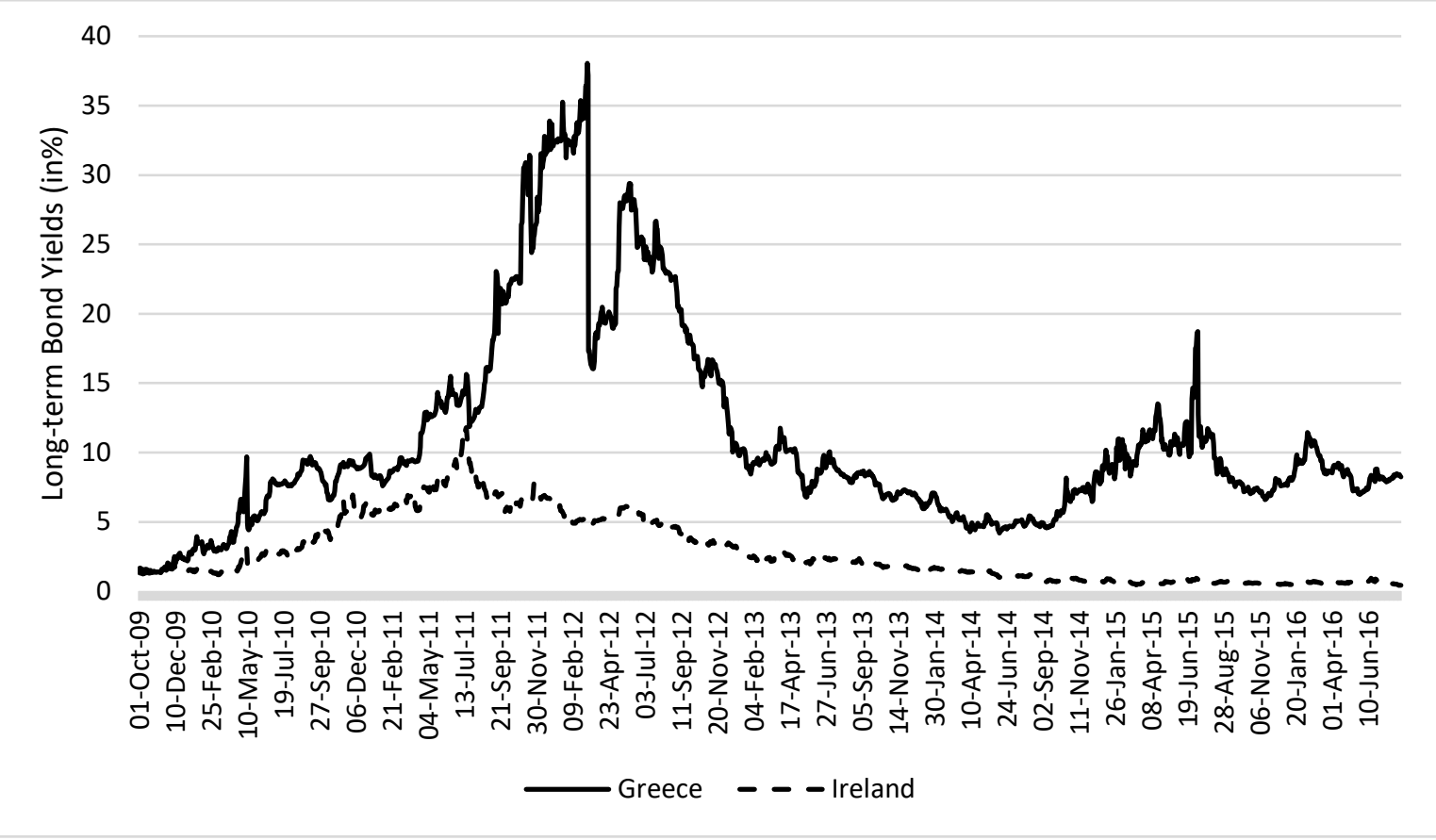




\section{Table 1. Correlations between the extreme values news events and crises countries}

Table 1A: Correlations between the extreme values news events [20 Oct 2009 - 30 Apr 2014]

\begin{tabular}{lcc}
\hline & Important News & $\begin{array}{c}\text { No. of } \\
\text { events }\end{array}$ \\
\hline EXVGR & $0.99 * * *$ & 374 \\
EXVIR & $0.99 * * *$ & 373 \\
EXVPO & $0.99 * * *$ & 444 \\
EXVSP & $0.99 * * *$ & 447 \\
EXVIT & $0.99 * * *$ & 453 \\
\hline No. of & 80 & \\
events & & \\
\hline
\end{tabular}

Table 1B: Correlation between PIIGS news events

\begin{tabular}{lccccc}
\hline & EXVGR & EXVIR & EXVPO & EXVSP & EXVIT \\
EXVGR & 1 & 0.25 & 0.83 & 0.63 & 0.84 \\
EXVIR & & 1 & 0.39 & 0.03 & 0.20 \\
EXVPO & & & 1 & 0.57 & 0.78 \\
EXVSP & & & & 1 & 0.78 \\
EXVIT & & & & & 1 \\
\hline
\end{tabular}

Notes: $* * *$ indicates the significant level of $1 \%$. where EXV refers to the extreme value of the interest rate differential and the country identifiers are $\mathrm{GE}=$ Greece, $\mathrm{IR}=$ Ireland, $\mathrm{PO}=$ Portugal, $\mathrm{SP}=$ Spain, and IT= Italy 
Table 2A. Estimation results from the aDCC- M-eGARCH model (with Static Exchange Rate Expectations)

\begin{tabular}{|c|c|c|c|c|c|c|c|c|c|c|}
\hline & \multicolumn{6}{|c|}{ Mean relation } & \multicolumn{4}{|c|}{ Variance model } \\
\hline & $\mathrm{C}_{\text {刍 }}$ & $\mathrm{C}_{66^{\circ}}$ & $\mathrm{C}_{30^{\circ}}$ & $\mathrm{c}_{\text {бाष }}$ & $\mathrm{c}_{\text {๘ }}$ & $c_{28}$ & 6 & Q & $\odot$ & $\gamma$ \\
\hline Greece & $\begin{array}{c}7.99 * * * \\
(0.44)\end{array}$ & & $\begin{array}{l}1.09 * * \\
(0.48)\end{array}$ & $\begin{array}{c}5.07 * * * \\
(0.32)\end{array}$ & $\begin{array}{l}1.43^{* * *} \\
(0.61)\end{array}$ & $\begin{array}{c}0.34 \\
(0.30)\end{array}$ & $\begin{array}{c}0.75^{* * * *} \\
(0.09)\end{array}$ & $\begin{array}{c}0.24 * * * \\
(0.09)\end{array}$ & $\begin{array}{c}0.05 * * * \\
(0.02)\end{array}$ & \\
\hline Ireland & $\begin{array}{c}0.65^{* * *} \\
(0.01) \\
\end{array}$ & $\begin{array}{c}0.04 \\
(0.03) \\
\end{array}$ & & $\begin{array}{c}0.04 \\
(0.08) \\
\end{array}$ & $\begin{array}{l}-0.01 \\
(0.02) \\
\end{array}$ & $\begin{array}{c}0.74 * * * \\
(0.10) \\
\end{array}$ & $\begin{array}{c}0.91^{* * *} \\
(0.04)\end{array}$ & $\begin{array}{l}0.08^{* *} \\
(0.04) \\
\end{array}$ & $\begin{array}{c}0.002 * * * \\
(0.0005)\end{array}$ & \\
\hline Portugal & $\begin{array}{c}2.19^{* * *} \\
(0.04)\end{array}$ & $\begin{array}{c}0.21 \\
(0.45) \\
\end{array}$ & $\begin{array}{c}2.10^{* * * *} \\
(0.07) \\
\end{array}$ & & $\begin{array}{c}1.02 * * * \\
(0.26) \\
\end{array}$ & $\begin{array}{c}0.55 \\
(0.46) \\
\end{array}$ & $\begin{array}{c}0.68^{* * * *} \\
(0.10)\end{array}$ & $\begin{array}{l}0.31 * * \\
(0.12) \\
\end{array}$ & $\begin{array}{c}0.01 \\
(0.01) \\
\end{array}$ & \\
\hline Spain & $\begin{array}{c}1.36^{* * *} \\
(0.01)\end{array}$ & $\begin{array}{c}0.02 \\
(0.24) \\
\end{array}$ & $\begin{array}{c}0.76^{* * *} \\
(0.07) \\
\end{array}$ & $\begin{array}{c}0.54 * * * \\
(0.19) \\
\end{array}$ & & $\begin{array}{c}0.34 \\
(0.36) \\
\end{array}$ & $\begin{array}{c}-0.0002 \\
(0.02) \\
\end{array}$ & $\begin{array}{c}0.95^{* * *} \\
(0.01) \\
\end{array}$ & $\begin{array}{c}-0.19 * * * \\
(0.04) \\
\end{array}$ & $\begin{array}{c}1.00^{* * * *} \\
(0.24)\end{array}$ \\
\hline Italy & $\begin{array}{c}1.38^{* * * *} \\
(0.01) \\
\end{array}$ & $\begin{array}{c}0.39 * * * \\
(0.02) \\
\end{array}$ & $\begin{array}{c}0.26^{* * * *} \\
(0.004) \\
\end{array}$ & $\begin{array}{c}1.12 * * * \\
(0.02) \\
\end{array}$ & $\begin{array}{c}0.25^{* * * *} \\
(0.10) \\
\end{array}$ & & $\begin{array}{c}0.03 \\
(0.02) \\
\end{array}$ & $\begin{array}{c}0.93^{* * *} \\
(0.02) \\
\end{array}$ & $\begin{array}{c}-0.25 * * * \\
(0.05) \\
\end{array}$ & $\begin{array}{c}1.15^{* * * *} \\
(0.17) \\
\end{array}$ \\
\hline France & $\begin{array}{l}0.35^{* * * *} \\
(0.003) \\
\end{array}$ & $\begin{array}{c}-0.47 * * * \\
(0.01) \\
\end{array}$ & $\begin{array}{c}0.02 * * * \\
(0.003)\end{array}$ & $\begin{array}{c}0.11^{* * *} \\
(0.004)\end{array}$ & $\begin{array}{c}0.29 * * * \\
(0.01) \\
\end{array}$ & $\begin{array}{c}0.01 \text { *** } \\
(0.004)\end{array}$ & $\begin{array}{c}0.03 \\
(0.02) \\
\end{array}$ & $\begin{array}{c}0.95^{* * *} \\
(0.01) \\
\end{array}$ & $\begin{array}{c}-0.28 * * * \\
(0.06) \\
\end{array}$ & $\begin{array}{c}0.85^{* * * *} \\
(0.06) \\
\end{array}$ \\
\hline Netherlands & $\begin{array}{c}0.21 * * * \\
(0.004) \\
\end{array}$ & $\begin{array}{l}-0.001 \\
(0.03) \\
\end{array}$ & $\begin{array}{c}0.07 * * * \\
(0.01) \\
\end{array}$ & $\begin{array}{c}0.01 \\
(0.02) \\
\end{array}$ & $\begin{array}{l}-0.01 \\
(0.01) \\
\end{array}$ & $\begin{array}{c}0.06^{* * *} \\
(0.01) \\
\end{array}$ & $\begin{array}{c}0.01 \\
(0.02) \\
\end{array}$ & $\begin{array}{c}0.88^{* * *} \\
(0.02) \\
\end{array}$ & $\begin{array}{c}-0.78 * * * \\
(0.13) \\
\end{array}$ & $\begin{array}{c}1.20^{* * * *} \\
(0.10)\end{array}$ \\
\hline Belgium & $\begin{array}{c}2.42^{* * *} \\
(0.01) \\
\end{array}$ & $\begin{array}{c}0.22 * * * \\
(0.01) \\
\end{array}$ & $\begin{array}{c}0.80^{* * * *} \\
(0.01) \\
\end{array}$ & $\begin{array}{c}0.94 * * * \\
(0.01) \\
\end{array}$ & $\begin{array}{c}0.07 * * * \\
(0.002) \\
\end{array}$ & $\begin{array}{c}-0.04 * * * \\
(0.004) \\
\end{array}$ & $\begin{array}{l}-0.04 * \\
(0.02) \\
\end{array}$ & $\begin{array}{c}0.93^{* * *} \\
(0.01)\end{array}$ & $\begin{array}{c}-0.23 * * * \\
(0.03) \\
\end{array}$ & $\begin{array}{c}1.22 * * * \\
(0.11) \\
\end{array}$ \\
\hline Poland & $\begin{array}{c}2.26^{* * *} \\
(0.01)\end{array}$ & $\begin{array}{c}0.63 * * * \\
(0.03)\end{array}$ & $\begin{array}{c}0.84 * * * \\
(0.02)\end{array}$ & $\begin{array}{c}-0.09 * * * \\
(0.01) \\
\end{array}$ & $\begin{array}{c}0.13 * * * \\
(0.01)\end{array}$ & $\begin{array}{c}0.13^{* * *} \\
(0.01)\end{array}$ & $\begin{array}{l}0.05^{* *} \\
(0.02)\end{array}$ & $\begin{array}{c}0.88^{* * *} \\
(0.03) \\
\end{array}$ & $\begin{array}{c}-0.44 * * * \\
(0.10) \\
\end{array}$ & $\begin{array}{c}1.09 * * * \\
(0.15)\end{array}$ \\
\hline $\begin{array}{l}\text { Czech } \\
\text { Republic }\end{array}$ & $\begin{array}{c}0.31^{* * * *} \\
(0.02) \\
\end{array}$ & $\begin{array}{c}0.33 * * * \\
(0.02) \\
\end{array}$ & $\begin{array}{c}0.46^{* * *} \\
(0.03) \\
\end{array}$ & $\begin{array}{l}0.06^{* *} \\
(0.03) \\
\end{array}$ & $\begin{array}{c}0.20 * * * \\
(0.03) \\
\end{array}$ & $\begin{array}{l}0.10^{* *} \\
(0.05) \\
\end{array}$ & $\begin{array}{l}0.05^{*} \\
(0.02) \\
\end{array}$ & $\begin{array}{c}0.89^{* * *} \\
(0.02) \\
\end{array}$ & $\begin{array}{c}-0.44 * * * \\
(0.09) \\
\end{array}$ & $\begin{array}{c}1.04 * * * \\
(0.25) \\
\end{array}$ \\
\hline Hungary & $\begin{array}{c}3.23^{* * * *} \\
(0.01) \\
\end{array}$ & $\begin{array}{c}0.48 * * * \\
(0.01) \\
\end{array}$ & $\begin{array}{c}1.10^{* * * *} \\
(0.03)\end{array}$ & $\begin{array}{c}0.30^{* * *} \\
(0.01) \\
\end{array}$ & $\begin{array}{c}0.04 * * * \\
(0.01) \\
\end{array}$ & $\begin{array}{c}0.53 * * * \\
(0.01) \\
\end{array}$ & $\begin{array}{l}0.09^{* *} \\
(0.04) \\
\end{array}$ & $\begin{array}{c}0.90^{* * *} \\
(0.02) \\
\end{array}$ & $\begin{array}{c}-0.27 * * * \\
(0.06) \\
\end{array}$ & $\begin{array}{c}1.15^{* * *} \\
(0.13)\end{array}$ \\
\hline Switzerland & $\begin{array}{c}-0.64 * * * \\
(0.003) \\
\end{array}$ & $\begin{array}{c}-0.18^{* * *} \\
(0.02) \\
\end{array}$ & $\begin{array}{c}-0.56^{* * *} \\
(0.01) \\
\end{array}$ & $\begin{array}{c}-0.10 * * * \\
(0.005) \\
\end{array}$ & $\begin{array}{c}-0.26^{* * *} \\
(0.01) \\
\end{array}$ & $\begin{array}{c}-0.04 * * * \\
(0.01) \\
\end{array}$ & $\begin{array}{l}0.03^{* *} \\
(0.01)\end{array}$ & $\begin{array}{c}0.93^{* * *} \\
(0.01) \\
\end{array}$ & $\begin{array}{c}-0.34 * * * \\
(0.07) \\
\end{array}$ & $\begin{array}{c}0.96^{* * *} \\
(0.12) \\
\end{array}$ \\
\hline U.K. & $\begin{array}{c}1.19^{* * *} \\
(0.03)\end{array}$ & $\begin{array}{c}0.21 * * * \\
(0.02)\end{array}$ & $\begin{array}{c}-0.62 * * * \\
(0.03)\end{array}$ & $\begin{array}{c}-0.27 * * * \\
(0.01)\end{array}$ & $\begin{array}{c}-0.68 * * * \\
(0.03)\end{array}$ & $\begin{array}{c}-0.06 * * * \\
(0.01)\end{array}$ & $\begin{array}{c}0.01 \\
(0.01)\end{array}$ & $\begin{array}{c}0.93^{* * *} \\
(0.01)\end{array}$ & $\begin{array}{c}-0.27 * * * \\
(0.05)\end{array}$ & $\begin{array}{c}0.78^{* * * *} \\
(0.07)\end{array}$ \\
\hline Sweden & $\begin{array}{c}0.37 * * * \\
(0.01)\end{array}$ & $\begin{array}{c}-0.14 * * * \\
(0.005)\end{array}$ & $\begin{array}{c}-0.19 * * * \\
(0.01)\end{array}$ & $\begin{array}{c}-0.23 * * * \\
(0.01)\end{array}$ & $\begin{array}{c}0.01 \\
(0.02)\end{array}$ & $\begin{array}{c}0.02 * * * \\
(0.001)\end{array}$ & $\begin{array}{c}0.01 \\
(0.02)\end{array}$ & $\begin{array}{c}0.85^{* * *} \\
(0.02)\end{array}$ & $\begin{array}{c}-0.72 * * * \\
(0.10)\end{array}$ & $\begin{array}{c}1.32 * * * \\
(0.16)\end{array}$ \\
\hline
\end{tabular}

Note: Estimation Results from the aDCC-M-eGARCH-TGARCH and the aDCC-M-eGARCH-NAGARCH models are the same as these; and

$* * *, * *$ and $*$ indicate the significant levels of $1 \%, 5 \%$ and $10 \%$ respectively.

Diagnostics: LL = 18241.26, !! $=0.39$ (0.02), ! $!_{2}=0.58$ (0.02) and !! $=0.01$ (0.002), AIC=-20.61, BIC=-19.84, H-Q=-20.33

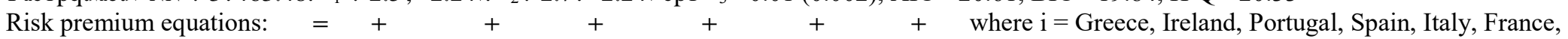

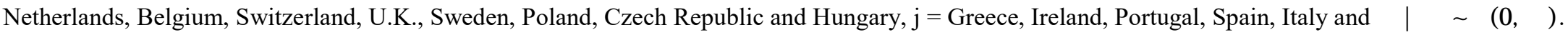

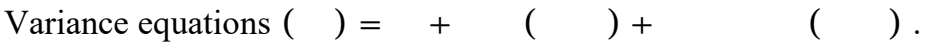


Table 2B: Estimation Results from the Quantile Model (with Static Exchange Rate Expectations)

\begin{tabular}{|c|c|c|c|c|c|c|c|c|c|}
\hline & & & & & & & \multicolumn{3}{|c|}{ Diagnostics } \\
\hline & $C_{n: F}$ & $\mathrm{C}_{56^{\circ}}$ & $\mathrm{C}_{30^{\circ}}$ & $\mathrm{C}_{\text {สष }}$ & $\mathrm{C}_{\text {๑ }}$ & $\mathrm{C}_{2 \bigotimes}$ & $\begin{array}{c}0.25 \\
\text { Pseudo } \\
\text { R-square }\end{array}$ & $\begin{array}{c}0.50 \\
\text { Pseudo } \\
\text { R-square }\end{array}$ & $\begin{array}{c}0.75 \\
\text { Pseudo } \\
\text { R-square }\end{array}$ \\
\hline Greece & $\begin{array}{c}8.97 * * * \\
(0.12)\end{array}$ & & $\begin{array}{c}3.69 * * * \\
(0.30)\end{array}$ & $\begin{array}{c}7.08 * * * \\
(0.50)\end{array}$ & $\begin{array}{c}0.53 \\
(0.29)\end{array}$ & $\begin{array}{c}7.64 * * * \\
(0.60)\end{array}$ & & & 0.50 \\
\hline Ireland & $\begin{array}{c}2.67 * * * \\
(0.09)\end{array}$ & $\begin{array}{c}-2.24 * * * \\
(0.30)\end{array}$ & & $\begin{array}{c}5.12 * * * \\
(0.31)\end{array}$ & $\begin{array}{c}0.10 \\
(0.09)\end{array}$ & $\begin{array}{c}0.61 * * * \\
(0.07)\end{array}$ & & & 0.26 \\
\hline Portugal & $\begin{array}{c}3.94 * * * \\
(0.13)\end{array}$ & $\begin{array}{c}1.95 * * * \\
(0.27)\end{array}$ & $\begin{array}{c}3.01 * * * \\
(0.29)\end{array}$ & & $\begin{array}{c}0.82 * * * \\
(0.15)\end{array}$ & $\begin{array}{c}1.97 * * * \\
(0.14)\end{array}$ & & & 0.46 \\
\hline Spain & $\begin{array}{c}2.33 * * * \\
(0.05)\end{array}$ & $\begin{array}{l}-0.02 \\
(0.07) \\
\end{array}$ & $\begin{array}{l}-0.02 \\
(0.07) \\
\end{array}$ & $\begin{array}{c}0.58 * * * \\
(0.05)\end{array}$ & & $\begin{array}{c}1.85 * * * \\
(0.07)\end{array}$ & & & 0.28 \\
\hline Italy & $\begin{array}{c}1.87 * * * \\
(0.06)\end{array}$ & $\begin{array}{c}0.65 * * * \\
(0.06)\end{array}$ & $\begin{array}{c}0.02 \\
(0.06)\end{array}$ & $\begin{array}{c}1.02 * * * \\
(0.07)\end{array}$ & $\begin{array}{c}1.23 * * * \\
(0.07)\end{array}$ & & & & 0.41 \\
\hline France & $\begin{array}{c}0.48 * * * \\
(0.01)\end{array}$ & $\begin{array}{c}0.33 * * * \\
(0.03)\end{array}$ & $\begin{array}{l}-0.01 \\
(0.01)\end{array}$ & $\begin{array}{c}0.22 * * * \\
(0.03)\end{array}$ & $\begin{array}{c}0.14 * * * \\
(0.01)\end{array}$ & $\begin{array}{c}0.09 * * * \\
(0.02)\end{array}$ & & & 0.40 \\
\hline Netherlands & $\begin{array}{c}0.20 * * * \\
(0.003)\end{array}$ & $\begin{array}{c}0.003 \\
(0.02)\end{array}$ & $\begin{array}{c}0.07 * * * \\
(0.01)\end{array}$ & $\begin{array}{c}0.08 * * * \\
(0.01)\end{array}$ & $\begin{array}{c}0.01 \\
(0.01)\end{array}$ & $\begin{array}{c}0.04 * * * \\
(0.01)\end{array}$ & & 0.20 & \\
\hline Belgium & $\begin{array}{c}2.56 * * * \\
(0.03)\end{array}$ & $\begin{array}{c}0.91 * * * \\
(0.20)\end{array}$ & $\begin{array}{c}1.62 * * * \\
(0.05)\end{array}$ & $\begin{array}{c}0.17 \\
(0.09)\end{array}$ & $\begin{array}{l}-0.06 \\
(0.03)\end{array}$ & $\begin{array}{c}0.07 \\
(0.19)\end{array}$ & & & 0.36 \\
\hline Poland & $\begin{array}{c}2.80 * * * \\
(0.02)\end{array}$ & $\begin{array}{c}0.37 * * * \\
(0.04)\end{array}$ & $\begin{array}{c}0.37 * * * \\
(0.03)\end{array}$ & $\begin{array}{c}0.32 * * * \\
(0.04)\end{array}$ & $\begin{array}{c}-0.08 * * \\
(0.04)\end{array}$ & $\begin{array}{c}0.21 * * * \\
(0.04)\end{array}$ & & & 0.38 \\
\hline $\begin{array}{l}\text { Czech } \\
\text { Republic }\end{array}$ & $\begin{array}{c}0.36 * * * \\
(0.01)\end{array}$ & $\begin{array}{c}0.39 * * * \\
(0.06)\end{array}$ & $\begin{array}{c}0.48 * * * \\
(0.03)\end{array}$ & $\begin{array}{c}0.14 * * * \\
(0.04)\end{array}$ & $\begin{array}{c}0.11 * * * \\
(0.02)\end{array}$ & $\begin{array}{c}0.12 * * * \\
(0.03)\end{array}$ & & 0.39 & \\
\hline Hungary & $\begin{array}{c}4.38 * * * \\
(0.05)\end{array}$ & $\begin{array}{c}0.67 * * * \\
(0.10)\end{array}$ & $\begin{array}{c}0.56^{* * *} \\
(0.12)\end{array}$ & $\begin{array}{c}0.43 * * * \\
(0.12)\end{array}$ & $\begin{array}{c}0.42^{* * *} \\
(0.07)\end{array}$ & $\begin{array}{c}0.74 * * * \\
(0.12)\end{array}$ & & & 0.39 \\
\hline Switzerland & $\begin{array}{c}-0.83 * * * \\
(0.01)\end{array}$ & $\begin{array}{c}-0.14 * * * \\
(0.05)\end{array}$ & $\begin{array}{c}-0.38 * * * \\
(0.02)\end{array}$ & $\begin{array}{c}-0.09 * * * \\
(0.03)\end{array}$ & $\begin{array}{c}-0.11 * * * \\
(0.02)\end{array}$ & $\begin{array}{l}-0.04 \\
(0.02)\end{array}$ & 0.25 & & \\
\hline U.K. & $\begin{array}{c}1.11 * * * \\
(0.01)\end{array}$ & $\begin{array}{c}0.21 * * * \\
(0.05)\end{array}$ & $\begin{array}{c}-0.56^{* * *} * \\
(0.02)\end{array}$ & $\begin{array}{c}-0.20 * * * \\
(0.02)\end{array}$ & $\begin{array}{c}-0.55 * * * \\
(0.03)\end{array}$ & $\begin{array}{l}-0.07 \\
(0.05)\end{array}$ & & 0.37 & \\
\hline Sweden & $\begin{array}{c}0.53 * * * \\
(0.01)\end{array}$ & $\begin{array}{c}-0.04 \\
(0.03)\end{array}$ & $\begin{array}{c}-0.18 * * * \\
(0.02)\end{array}$ & $\begin{array}{c}-0.34 * * * \\
(0.03)\end{array}$ & $\begin{array}{c}-0.05 * * \\
(0.02)\end{array}$ & $\begin{array}{l}0.004 \\
(0.02)\end{array}$ & & & 0.35 \\
\hline
\end{tabular}

Note: $* * *$ and $* *$ indicate the significant levels of $1 \%$ and $5 \%$ respectively.

Number of observations $=1746$

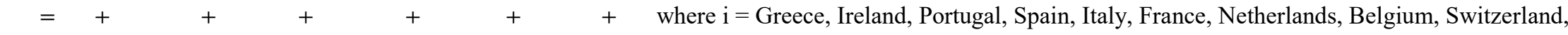

U.K., Sweden, Poland, Czech Republic and Hungary 
Table 3A Estimation Results from the aDCC- M-eGARCH model (with Static Exchange Rate Expectations and weekly data) Data

\begin{tabular}{|c|c|c|c|c|c|c|c|c|c|c|}
\hline & \multicolumn{6}{|c|}{ Mean relation } & \multicolumn{4}{|c|}{ Variance model } \\
\hline & $\mathrm{C}_{\text {很 }}$ & $c_{960^{\circ}}$ & $\mathrm{C}_{\mathscr{O}}$ & $\mathrm{c}_{\text {ตाฒ }}$ & $\mathrm{c}_{\text {๘ன }}$ & $c_{88}$ & ๔ & Q & ๑ & $\gamma$ \\
\hline Greece & $\begin{array}{c}7.91 * * * \\
(0.28)\end{array}$ & & $\begin{array}{c}1.81^{* * * *} \\
(0.34)\end{array}$ & $\begin{array}{c}3.31 \\
(12.88)\end{array}$ & $\begin{array}{c}1.51^{* * * *} \\
(0.55)\end{array}$ & $\begin{array}{c}0.39 \\
(0.70)\end{array}$ & $\begin{array}{c}0.84^{* * * *} \\
(0.32)\end{array}$ & $\begin{array}{c}0.15^{* *} \\
(0.07)\end{array}$ & $\begin{array}{l}0.13 * * \\
(0.05)\end{array}$ & \\
\hline Ireland & $\begin{array}{c}1.09^{* * * *} \\
(0.01)\end{array}$ & $\begin{array}{c}-1.27 * * * \\
(0.06)\end{array}$ & & $\begin{array}{c}-1.25^{* * *} \\
(0.08)\end{array}$ & $\begin{array}{c}1.55^{* * * *} \\
(0.08)\end{array}$ & $\begin{array}{c}1.07 * * * \\
(0.10)\end{array}$ & $\begin{array}{c}0.11 \\
(0.08)\end{array}$ & $\begin{array}{c}0.86^{* * *} \\
(0.04)\end{array}$ & $\begin{array}{c}-0.21^{* *} \\
(0.09)\end{array}$ & $\begin{array}{c}2.22 * * * \\
(0.28)\end{array}$ \\
\hline Portugal & $\begin{array}{c}2.20 * * * \\
(0.06)\end{array}$ & $\begin{array}{c}1.07 * * * \\
(0.18) \\
\end{array}$ & $\begin{array}{c}1.75^{* * * *} \\
(0.13) \\
\end{array}$ & & $\begin{array}{c}0.55^{* * *} \\
(0.14) \\
\end{array}$ & $\begin{array}{l}-0.16 \\
(0.17)\end{array}$ & $\begin{array}{c}0.82^{* * *} \\
(0.08)\end{array}$ & $\begin{array}{c}0.17^{* * *} \\
(0.06)\end{array}$ & $\begin{array}{l}0.03 * \\
(0.01)\end{array}$ & \\
\hline Spain & $\begin{array}{c}1.36^{* * * *} \\
(0.01)\end{array}$ & $\begin{array}{c}-0.04 * * * \\
(0.001)\end{array}$ & $\begin{array}{c}0.80^{* * *} \\
(0.02)\end{array}$ & $\begin{array}{c}-0.16^{* * *} \\
(0.01)\end{array}$ & & $\begin{array}{c}0.07 * * * \\
(0.001)\end{array}$ & $\begin{array}{c}0.11 \\
(0.19)\end{array}$ & $\begin{array}{c}0.85^{* * * *} \\
(0.09)\end{array}$ & $\begin{array}{l}-0.41^{*} \\
(0.23)\end{array}$ & $\begin{array}{c}1.71 * * * \\
(0.50)\end{array}$ \\
\hline Italy & $\begin{array}{c}1.35^{* * * *} \\
(0.01)\end{array}$ & $\begin{array}{c}-0.12 * * * \\
(0.05)\end{array}$ & $\begin{array}{c}0.29 * * * \\
(0.01)\end{array}$ & $\begin{array}{l}-0.002 \\
(0.01)\end{array}$ & $\begin{array}{c}-0.54 * * * \\
(0.02)\end{array}$ & & $\begin{array}{c}0.12 \\
(0.09)\end{array}$ & $\begin{array}{c}0.85^{* * *} \\
(0.04)\end{array}$ & $\begin{array}{c}-0.42 * * * \\
(0.10)\end{array}$ & $\begin{array}{c}1.61 * * * \\
(0.24)\end{array}$ \\
\hline France & $\begin{array}{c}0.35^{* * * *} \\
(0.004)\end{array}$ & $\begin{array}{c}0.32 * * * \\
(0.03)\end{array}$ & $\begin{array}{c}0.02 * * * \\
(0.01)\end{array}$ & $\begin{array}{c}0.12^{* * *} \\
(0.02)\end{array}$ & $\begin{array}{c}0.27 * * * \\
(0.01)\end{array}$ & $\begin{array}{c}0.07 * * * \\
(0.01)\end{array}$ & $\begin{array}{l}-0.02 \\
(0.05)\end{array}$ & $\begin{array}{c}0.86^{* * *} \\
(0.04)\end{array}$ & $\begin{array}{c}-0.67 * * * \\
(0.16)\end{array}$ & $\begin{array}{c}1.31 * * * \\
(0.11)\end{array}$ \\
\hline Netherlands & $\begin{array}{c}0.19^{* * * *} \\
(0.001)\end{array}$ & $\begin{array}{c}0.01 \\
(0.01)\end{array}$ & $\begin{array}{c}0.09^{* * * *} \\
(0.001)\end{array}$ & $\begin{array}{c}0.03^{* * *} \\
(0.01)\end{array}$ & $\begin{array}{c}0.01 \\
(0.01)\end{array}$ & $\begin{array}{c}0.05 * * * \\
(0.01)\end{array}$ & $\begin{array}{c}0.06 \\
(0.10)\end{array}$ & $\begin{array}{c}0.66^{* * *} \\
(0.03)\end{array}$ & $\begin{array}{c}-2.03 * * * \\
(0.18)\end{array}$ & $\begin{array}{c}2.15 * * * \\
(0.22)\end{array}$ \\
\hline Belgium & $\begin{array}{c}2.50 * * * \\
(0.01)\end{array}$ & $\begin{array}{c}0.40 * * * \\
(0.01)\end{array}$ & $\begin{array}{c}0.28 * * * \\
(0.04)\end{array}$ & $\begin{array}{c}0.77^{* * *} \\
(0.01)\end{array}$ & $\begin{array}{l}-0.05^{*} \\
(0.03)\end{array}$ & $\begin{array}{l}0.001 \\
(0.03)\end{array}$ & $\begin{array}{l}-0.13^{*} \\
(0.07)\end{array}$ & $\begin{array}{c}0.85^{* * *} \\
(0.04)\end{array}$ & $\begin{array}{c}-0.42 * * * \\
(0.05)\end{array}$ & $\begin{array}{c}2.22 * * * \\
(0.16)\end{array}$ \\
\hline Poland & $\begin{array}{c}2.26^{* * * *} \\
(0.02) \\
\end{array}$ & $\begin{array}{c}0.34 * * * \\
(0.08) \\
\end{array}$ & $\begin{array}{c}0.82 * * * \\
(0.04) \\
\end{array}$ & $\begin{array}{c}0.05 \\
(0.10) \\
\end{array}$ & $\begin{array}{c}0.16^{* * * *} \\
(0.01) \\
\end{array}$ & $\begin{array}{l}0.24 * * \\
(0.10)\end{array}$ & $\begin{array}{c}0.03 \\
(0.06) \\
\end{array}$ & $\begin{array}{c}0.80^{* * *} \\
(0.06)\end{array}$ & $\begin{array}{c}-0.57 * * * \\
(0.15) \\
\end{array}$ & $\begin{array}{c}1.07 * * * \\
(0.14)\end{array}$ \\
\hline $\begin{array}{l}\text { Czech } \\
\text { Republic }\end{array}$ & $\begin{array}{c}0.33^{* * * *} \\
(0.02)\end{array}$ & $\begin{array}{c}0.27 * * * \\
(0.03)\end{array}$ & $\begin{array}{c}0.40^{* * * *} \\
(0.04)\end{array}$ & $\begin{array}{c}0.05 \\
(0.03)\end{array}$ & $\begin{array}{c}0.21 * * * \\
(0.03)\end{array}$ & $\begin{array}{c}0.13 * * * \\
(0.03)\end{array}$ & $\begin{array}{c}0.09 \\
(0.07)\end{array}$ & $\begin{array}{c}0.74^{* * *} \\
(0.06)\end{array}$ & $\begin{array}{c}-0.95 * * * \\
(0.21)\end{array}$ & $\begin{array}{c}1.58 * * * \\
(0.20)\end{array}$ \\
\hline Hungary & $\begin{array}{c}3.23^{* * * *} \\
(0.005)\end{array}$ & $\begin{array}{c}0.37 * * * \\
(0.02)\end{array}$ & $\begin{array}{c}0.91 * * * \\
(0.03)\end{array}$ & $\begin{array}{c}0.34 * * * \\
(0.02)\end{array}$ & $\begin{array}{c}1.75^{* * * *} \\
(0.02)\end{array}$ & $\begin{array}{c}0.39 * * * \\
(0.05)\end{array}$ & $\begin{array}{c}0.15 \\
(0.11)\end{array}$ & $\begin{array}{c}0.84 * * * \\
(0.07)\end{array}$ & $\begin{array}{c}-0.32 * * * \\
(0.10)\end{array}$ & $\begin{array}{c}2.19 * * * \\
(0.22)\end{array}$ \\
\hline Switzerland & $\begin{array}{c}-0.64 * * * \\
(0.004)\end{array}$ & $\begin{array}{c}-0.13 * * * \\
(0.02)\end{array}$ & $\begin{array}{c}-0.55^{* * *} \\
(0.01)\end{array}$ & $\begin{array}{c}-0.08 * * * \\
(0.01)\end{array}$ & $\begin{array}{c}-0.26 * * * \\
(0.02)\end{array}$ & $\begin{array}{l}-0.02 \\
(0.02)\end{array}$ & $\begin{array}{l}0.12^{*} \\
(0.06)\end{array}$ & $\begin{array}{c}0.81^{* * *} \\
(0.04)\end{array}$ & $\begin{array}{c}-0.75^{* * *} \\
(0.15)\end{array}$ & $\begin{array}{c}1.44 * * * \\
(0.19)\end{array}$ \\
\hline U.K. & $\begin{array}{c}1.19^{* * *} \\
(0.01)\end{array}$ & $\begin{array}{l}-0.06 \\
(0.05)\end{array}$ & $\begin{array}{c}-0.66^{* * *} * \\
(0.02)\end{array}$ & $\begin{array}{c}0.11 \\
(0.06)\end{array}$ & $\begin{array}{c}-0.71 * * * \\
(0.12)\end{array}$ & $\begin{array}{l}-0.09 \\
(0.17)\end{array}$ & $\begin{array}{l}-0.01 \\
(0.11)\end{array}$ & $\begin{array}{c}0.85^{* * * *} \\
(0.05)\end{array}$ & $\begin{array}{c}-0.54 * * * \\
(0.19)\end{array}$ & $\begin{array}{c}1.34 * * * \\
(0.35)\end{array}$ \\
\hline Sweden & $\begin{array}{c}0.46^{* * *} \\
(0.04)\end{array}$ & $\begin{array}{l}-0.22 \\
(0.20)\end{array}$ & $\begin{array}{c}-0.27 * * * \\
(0.03)\end{array}$ & $\begin{array}{c}-0.23 * * \\
(0.12)\end{array}$ & $\begin{array}{l}-0.04 \\
(0.03)\end{array}$ & $\begin{array}{c}0.05 \\
(0.05)\end{array}$ & $\begin{array}{c}-0.14 * * \\
(0.07)\end{array}$ & $\begin{array}{c}0.75^{* * * *} \\
(0.07)\end{array}$ & $\begin{array}{c}-1.12 * * * \\
(0.36)\end{array}$ & $\begin{array}{c}1.41 \\
(0.94)\end{array}$ \\
\hline Japan & $\begin{array}{c}-0.30 * * * \\
(0.02)\end{array}$ & $\begin{array}{l}0.12^{* *} \\
(0.05)\end{array}$ & $\begin{array}{c}0.02 \\
(0.05)\end{array}$ & $\begin{array}{c}-0.60 * * * \\
(0.04)\end{array}$ & $\begin{array}{l}-0.05 \\
(0.05)\end{array}$ & $\begin{array}{c}-0.15^{* * *} \\
(0.03)\end{array}$ & $\begin{array}{c}0.67^{* * * *} \\
(0.08)\end{array}$ & $\begin{array}{c}0.32^{* * * *} \\
(0.08)\end{array}$ & $\begin{array}{l}0.001^{* *} \\
(0.0004)\end{array}$ & \\
\hline U.S. & $\begin{array}{c}1.04 * * * \\
(0.005)\end{array}$ & $\begin{array}{c}0.21 * * * \\
(0.004) \\
\end{array}$ & $\begin{array}{c}-0.74 * * * \\
(0.01) \\
\end{array}$ & $\begin{array}{c}-0.05 * * * \\
(0.01) \\
\end{array}$ & $\begin{array}{c}-0.74 * * * \\
(0.01) \\
\end{array}$ & $\begin{array}{l}-0.02 \\
(0.01)\end{array}$ & $\begin{array}{l}0.09^{*} \\
(0.05)\end{array}$ & $\begin{array}{c}0.87^{* * * *} \\
(0.04)\end{array}$ & $\begin{array}{c}-0.50 * * * \\
(0.12) \\
\end{array}$ & $\begin{array}{c}1.74 * * * \\
(0.21) \\
\end{array}$ \\
\hline
\end{tabular}

Note: Estimation Results from the aDCC-M-eGARCH-TGARCH and the aDCC-M-eGARCH-NAGARCH models are the same as these.

Note: $* * *, * *$ and $*$ indicate the significant levels of $1 \%, 5 \%$ and $10 \%$ respectively.

Diagnostics: LL = 21767.93, !! $=0.54(0.03), ! ! 2=0.29(0.04)$ and !! $=0.01(0.005)$, AIC=-9.11, BIC=-5.90, H-Q=-7.83

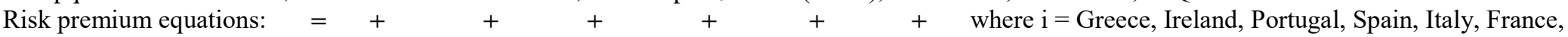

Netherlands, Belgium, Switzerland, U.K., Sweden, Japan, U.S., Poland, Czech Republic and Hungary, j = Greece, Ireland, Portugal, Spain, Italy and

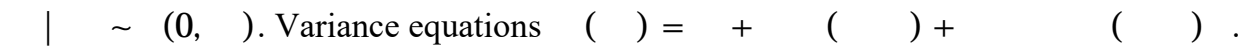


Table 3B: Estimation Results from the Quantile Model (Static Exchange Rate Expectations and weekly data)

\begin{tabular}{|c|c|c|c|c|c|c|c|c|c|}
\hline & & & & & & & \multicolumn{3}{|c|}{ Diagnostics } \\
\hline & $C_{n}$ & $C_{860^{\circ}}$ & $\mathrm{C}_{36^{\circ}}$ & $\mathrm{C}_{\text {สाष }}$ & $\mathrm{C}_{\text {๑ }}$ & $\mathrm{C}_{28}$ & $\begin{array}{c}0.25 \\
\text { Pseudo } \\
\text { R-square }\end{array}$ & $\begin{array}{c}0.50 \\
\text { Pseudo } \\
\text { R-square }\end{array}$ & $\begin{array}{c}0.75 \\
\text { Pseudo } \\
\text { R-square }\end{array}$ \\
\hline Greece & $\begin{array}{c}8.83 * * * \\
(0.15)\end{array}$ & & $\begin{array}{c}3.76 * * * \\
(0.81)\end{array}$ & $\begin{array}{c}7.21 * * * \\
(1.75)\end{array}$ & $\begin{array}{c}0.61 \\
(1.50)\end{array}$ & $\begin{array}{c}7.38 * * * \\
(1.99)\end{array}$ & & & 0.50 \\
\hline Ireland & $\begin{array}{c}2.58 * * * \\
(0.24)\end{array}$ & $\begin{array}{c}-3.34 * * * \\
(0.89)\end{array}$ & & $\begin{array}{c}6.08 * * * \\
(0.92)\end{array}$ & $\begin{array}{c}0.13 \\
(0.28) \\
\end{array}$ & $\begin{array}{c}0.71 * * \\
(0.28)\end{array}$ & & & 0.27 \\
\hline Portugal & $\begin{array}{c}3.85 * * * \\
(0.32)\end{array}$ & $\begin{array}{c}1.97 * * \\
(0.58)\end{array}$ & $\begin{array}{c}3.03 * * * \\
(0.53)\end{array}$ & & $\begin{array}{c}0.97 * * \\
(0.38)\end{array}$ & $\begin{array}{c}1.94 * * * \\
(0.33)\end{array}$ & & & 0.46 \\
\hline Spain & $\begin{array}{c}2.27 * * * \\
(0.16)\end{array}$ & $\begin{array}{l}-0.20 \\
(0.47)\end{array}$ & $\begin{array}{c}0.10 \\
(0.18) \\
\end{array}$ & $\begin{array}{c}0.41 * * \\
(0.17)\end{array}$ & & $\begin{array}{c}2.04 * * * \\
(0.21)\end{array}$ & & & 0.29 \\
\hline Italy & $\begin{array}{c}1.81 * * * \\
(0.14)\end{array}$ & $\begin{array}{c}0.59 * * * \\
(0.15) \\
\end{array}$ & $\begin{array}{c}0.02 \\
(0.16) \\
\end{array}$ & $\begin{array}{c}1.13 * * * \\
(0.13) \\
\end{array}$ & $\begin{array}{c}1.33 * * * \\
(0.16) \\
\end{array}$ & & & & 0.42 \\
\hline France & $\begin{array}{c}0.48 * * * \\
(0.03)\end{array}$ & $\begin{array}{c}0.32 * * * \\
(0.10)\end{array}$ & $\begin{array}{l}-0.03 \\
(0.12) \\
\end{array}$ & $\begin{array}{c}0.24 \\
(0.16) \\
\end{array}$ & $\begin{array}{c}0.15 * * * \\
(0.04)\end{array}$ & $\begin{array}{c}0.08 \\
(0.07) \\
\end{array}$ & & & 0.41 \\
\hline Netherlands & $\begin{array}{c}0.20 * * * \\
(0.01)\end{array}$ & $\begin{array}{l}-0.01 \\
(0.03)\end{array}$ & $\begin{array}{c}0.07 * * * \\
(0.01)\end{array}$ & $\begin{array}{c}0.09 * * * \\
(0.02)\end{array}$ & $\begin{array}{r}-0.002 \\
(0.03)\end{array}$ & $\begin{array}{c}0.05 \\
(0.04)\end{array}$ & & 0.21 & \\
\hline Belgium & $\begin{array}{c}2.55 * * * \\
(0.08)\end{array}$ & $\begin{array}{c}0.01 * * * \\
(0.36)\end{array}$ & $\begin{array}{c}1.64 * * * \\
(0.11)\end{array}$ & $\begin{array}{c}0.18 \\
(0.36) \\
\end{array}$ & $\begin{array}{l}-0.06 \\
(0.07) \\
\end{array}$ & $\begin{array}{l}-0.03 \\
(0.26) \\
\end{array}$ & & & 0.37 \\
\hline Poland & $\begin{array}{c}2.78 * * * \\
(0.05)\end{array}$ & $\begin{array}{c}0.38 * * * \\
(0.14)\end{array}$ & $\begin{array}{c}0.41 * * * \\
(0.07)\end{array}$ & $\begin{array}{c}0.25 \\
(0.14) \\
\end{array}$ & $\begin{array}{l}-0.15 \\
(0.11) \\
\end{array}$ & $\begin{array}{c}0.29 * * \\
(0.15)\end{array}$ & & & 0.39 \\
\hline $\begin{array}{l}\text { Czech } \\
\text { Republic }\end{array}$ & $\begin{array}{c}0.35 * * * \\
(0.03)\end{array}$ & $\begin{array}{c}0.35 * * * \\
(0.09)\end{array}$ & $\begin{array}{c}0.52 * * * \\
(0.06)\end{array}$ & $\begin{array}{c}0.16^{* *} \\
(0.08)\end{array}$ & $\begin{array}{c}0.13^{*} \\
(0.07)\end{array}$ & $\begin{array}{c}0.13 \\
(0.08) \\
\end{array}$ & & 0.40 & \\
\hline Hungary & $\begin{array}{c}4.35 * * * \\
(0.10)\end{array}$ & $\begin{array}{c}0.70 * * \\
(0.30)\end{array}$ & $\begin{array}{c}0.65 * * * \\
(0.23)\end{array}$ & $\begin{array}{c}0.33 \\
(0.41)\end{array}$ & $\begin{array}{c}0.46^{* * *} * \\
(0.13)\end{array}$ & $\begin{array}{c}0.78 * * * \\
(0.22)\end{array}$ & & & 0.40 \\
\hline Switzerland & $\begin{array}{c}-0.82 * * * \\
(0.02)\end{array}$ & $\begin{array}{l}-0.16^{*} \\
(0.08)\end{array}$ & $\begin{array}{c}-0.39 * * * \\
(0.02)\end{array}$ & $\begin{array}{l}-0.09 \\
(0.07) \\
\end{array}$ & $\begin{array}{c}-0.12 * * * \\
(0.04)\end{array}$ & $\begin{array}{l}-0.04 \\
(0.09) \\
\end{array}$ & 0.26 & & \\
\hline U.K. & $\begin{array}{c}1.13 * * * \\
(0.03)\end{array}$ & $\begin{array}{c}0.20 \\
(0.19) \\
\end{array}$ & $\begin{array}{c}-0.58 * * * \\
(0.06)\end{array}$ & $\begin{array}{c}-0.17 \\
(0.13)\end{array}$ & $\begin{array}{c}-0.60 * * * \\
(0.09)\end{array}$ & $\begin{array}{l}-0.03 \\
(0.19) \\
\end{array}$ & & 0.39 & \\
\hline Sweden & $\begin{array}{c}0.53 * * * \\
(0.01)\end{array}$ & $\begin{array}{c}-0.04 \\
(0.12) \\
\end{array}$ & $\begin{array}{c}-0.19 * * * \\
(0.04)\end{array}$ & $\begin{array}{c}-0.37 * * \\
(0.14)\end{array}$ & $\begin{array}{l}-0.02 \\
(0.07) \\
\end{array}$ & $\begin{array}{r}-0.004 \\
(0.10) \\
\end{array}$ & & & 0.36 \\
\hline Japan & $\begin{array}{c}-1.12 * * * \\
(0.04)\end{array}$ & $\begin{array}{c}-1.12 * * * \\
(0.42)\end{array}$ & $\begin{array}{c}-0.77 * * * \\
(0.10)\end{array}$ & $\begin{array}{c}0.07 \\
(0.09) \\
\end{array}$ & $\begin{array}{c}0.20 \\
(0.66) \\
\end{array}$ & $\begin{array}{c}0.16 \\
(0.66) \\
\end{array}$ & 0.18 & & \\
\hline U.S. & $\begin{array}{c}1.54 * * * \\
(0.02)\end{array}$ & $\begin{array}{c}0.04 \\
(0.31) \\
\end{array}$ & $\begin{array}{c}-0.52 * * * \\
(0.18)\end{array}$ & $\begin{array}{l}-0.20 \\
(0.34) \\
\end{array}$ & $\begin{array}{l}-0.12 \\
(0.44) \\
\end{array}$ & $\begin{array}{l}-0.71 \\
(0.47) \\
\end{array}$ & & & 0.37 \\
\hline
\end{tabular}

Note: $* * *$ and $* *$ indicate the significant levels of $1 \%$ and $5 \%$ respectively.

Number of observations $=359$

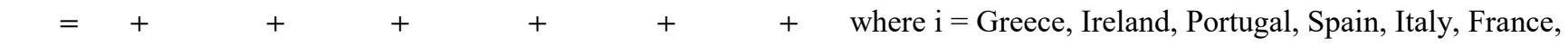

Netherlands, Belgium, Switzerland, U.K., Sweden, Japan, U.S., Poland, Czech Republic and Hungary 
Table 4: The Drivers of Contagion

\begin{tabular}{|c|c|c|c|c|c|}
\hline Specification: & $\mathbf{A}$ & B & $\mathbf{C}$ & D & $\mathbf{E}$ \\
\hline EXTR & $\begin{array}{l}0.0029 * * * \\
(5.43)\end{array}$ & & $\begin{array}{l}0.0028 * * * \\
(5.32)\end{array}$ & & $\begin{array}{c}0.0028 * * * \\
(5.40)\end{array}$ \\
\hline OPEN & & $\begin{array}{l}0.0011 * * \\
(2.67)\end{array}$ & & $\begin{array}{c}0.0010^{* *} \\
(2.50)\end{array}$ & \\
\hline ER & $\begin{array}{l}0.0146 \\
(0.15)\end{array}$ & $\begin{array}{c}0.0281 \\
(0.16)\end{array}$ & $\begin{array}{c}0.0100 \\
(0.07)\end{array}$ & $\begin{array}{c}0.0144 \\
(0.09)\end{array}$ & $\begin{array}{l}0.0087 \\
(0.06)\end{array}$ \\
\hline DEBT & $\begin{array}{c}0.2799^{* *} \\
(2.04)\end{array}$ & $\begin{array}{l}0.241^{*} \\
(1.87)\end{array}$ & $\begin{array}{l}0.312 * * * \\
(2.25)\end{array}$ & $\begin{array}{c}0.2771^{* *} \\
(2.11)\end{array}$ & $\begin{array}{c}0.2992^{* *} \\
(2.17)\end{array}$ \\
\hline EXBANK & $\begin{array}{l}0.0009 \\
(1.03)\end{array}$ & $\begin{array}{c}0.0034^{* * * *} \\
(4.26)\end{array}$ & $\begin{array}{c}0.0008 \\
(0.87)\end{array}$ & $\begin{array}{c}0.0034 * * * \\
(4.29)\end{array}$ & $\begin{array}{c}0.0008 \\
(0.97)\end{array}$ \\
\hline USINT & $\begin{array}{l}-0.113 \\
(-1.01)\end{array}$ & $\begin{array}{c}-0.1097 \\
(-1.00)\end{array}$ & $\begin{array}{c}-0.1219 \\
(-1.02)\end{array}$ & $\begin{array}{c}-0.1178 \\
(-1.02)\end{array}$ & \\
\hline DOWN & & & $\begin{array}{c}1.0788^{* *} \\
(2.96)\end{array}$ & $\begin{array}{l}1.1265^{* * *} \\
(3.25)\end{array}$ & $\begin{array}{c}1.0676^{* *} \\
(2.93)\end{array}$ \\
\hline LL stat & -276.37 & -294.112 & -272.275 & -289.213 & -272.864 \\
\hline $\operatorname{LR}\left(\chi^{2}\right)$ & $180.12^{* * *}$ & $158.27 * * *$ & $188.32 * * *$ & $167.95 * * *$ & $187.14^{* * *}$ \\
\hline
\end{tabular}

Notes: Conditional fixed effects logistic regressions grouped by country. Variables are defined as: EXV, the dependent variable, is a dummy variable with value 1 if a country has an extreme negative events and 0 otherwise; ENR ${ }^{\text {all }}$ is the percent of the sample with an extreme negative value in the given month; EXTR= trade between the individual countries and the Euro-zone ((imports from the Euro-zone + exports to the eurozone) / GDP)*ENR ${ }^{\text {all }}$; OPEN = general openness of individual countries trade (total imports + total exports)/ GDP) * ENR ${ }^{\text {all }}$; EXBANK = bank capital to assets ratio (\%) * ENR ${ }^{\text {all }} ;$ DEBT $=$ government debt to GDP ratio; USINT $=$ US interest rates measured as changes in the interest rate on a 10-year constant maturity government bond; $\mathbf{E R}=$ appreciation of the Euro against individual countries' local currency; DOWN = downgrades of an individual country's credit rating.

$* * *, * *$ and $*$ indicate the significance levels of $1 \%, 5 \%$ and $10 \%$ respectively. LR is the likelihood ratio test for equation significance, which is distributed as chi-squared with 5 or 6 degrees for freedom. 


\section{On line Appendix: Tables 5 to 10 and Figures 2 and 3}

\section{Table 5. List of Important News Events}

\begin{tabular}{|c|c|}
\hline Date & News \\
\hline $4 / 9 / 2010$ & $\begin{array}{l}\text { Bank of Ireland has watered down a number of pension benefits for existing staff as a } \\
\text { way of boosting its income as the bank takes action to clean up its balance sheet. }\end{array}$ \\
\hline $4 / 12 / 2010$ & $\begin{array}{l}\text { Finance ministers from the } 16 \text { countries in the Euro-zone agree } € 30 \text { billion bailout } \\
\text { terms for Greece. }\end{array}$ \\
\hline $4 / 28 / 2010$ & $\begin{array}{l}\text { José Sócrates, Portugal's prime minister, announces that the minority Socialist } \\
\text { government will immediately implement austerity measures initially planned for } \\
\text { 2011-13 in response to "speculative attacks against Portugal's sovereign debt". }\end{array}$ \\
\hline $4 / 29 / 2010$ & $\begin{array}{l}\text { Greece agrees with the IMF, EU to take additional austerity measures as a } \\
\text { precondition for financial assistance. }\end{array}$ \\
\hline $5 / 10 / 2010$ & $\begin{array}{l}\text { Troika agrees a rescue package, including } € 720 \text { billion of government-backed loan } \\
\text { guarantees and a commitment to buy European sovereign bonds. }\end{array}$ \\
\hline $5 / 11 / 2010$ & $\begin{array}{l}\text { Portugal recorded the strongest economic growth in the EU in the first quarter of this } \\
\text { year, lifting the prospects of recovery in a country struggling to control gaping public } \\
\text { deficits. }\end{array}$ \\
\hline $6 / 17 / 2010$ & $\begin{array}{l}\text { Staff teams from Troika visited Athens during June } 14-17 \text { to follow up on recent } \\
\text { developments and implementation of policies under the economic program for } \\
\text { Greece. Visiting officials from the Troika say that Greece's fiscal consolidation effort } \\
\text { remains on track and its recession could be shallower than projected. }\end{array}$ \\
\hline $6 / 18 / 2010$ & $\begin{array}{l}\text { Leaders move to restore confidence in Europe's financial stability and reinforce } \\
\text { economic governance. }\end{array}$ \\
\hline $11 / 23 / 2010$ & $\begin{array}{l}\text { Spain imposes strict limits on the budgets of its } 17 \text { autonomous regions, seeking to } \\
\text { defuse concerns about regional spending and debt issuance that could undermine the } \\
\text { closely watched national austerity drive. }\end{array}$ \\
\hline $11 / 24 / 2010$ & $\begin{array}{l}\text { Spain imposes strict limits on the budgets of its } 17 \text { autonomous regions, seeking to } \\
\text { defuse concerns about regional spending and debt issuance that could undermine the } \\
\text { closely watched national austerity drive. }\end{array}$ \\
\hline $12 / 9 / 2010$ & $\begin{array}{l}\text { Olli Rehn forecasts that Greece's economy will recover in the second half of } 2011 \\
\text { after the country's longest recession in memory. }\end{array}$ \\
\hline $12 / 10 / 2010$ & $\begin{array}{l}\text { An IMF spokesperson states that the Government of Ireland decided to table a motion } \\
\text { on the EU-IMF Financial Assistance Program for Ireland in the Irish parliament, } \\
\text { assuming parliamentary support for the package, the Managing Director could } \\
\text { recommend approval by the IMF Executive Board of the proposed } € 22.5 \text { billion IMF } \\
\text { loan as early as December } 16 \text {. }\end{array}$ \\
\hline $1 / 11 / 2011$ & $\begin{array}{l}\text { The Bank of Portugal predicted that the economy would contract by } 1.3 \text { per cent in } \\
2011 \text {, compared with an initial government forecast of } 0.7 \text { percent. }\end{array}$ \\
\hline $1 / 12 / 2011$ & $\begin{array}{l}\text { Report sets } 10 \text { priorities for tackling the bloc's main economic challenges, launching } \\
\text { the first ever "European semester." }\end{array}$ \\
\hline $1 / 31 / 2011$ & $\begin{array}{l}\text { ECB suspended its emergency purchases of Euro-zone government bonds last week as } \\
\text { the debt crisis eased, allowing it to focus on combating rising inflation. }\end{array}$ \\
\hline $2 / 1 / 2011$ & $\begin{array}{l}\text { ECB crisis-fighting measures have hit an unexpected snag with the surprise flop of } \\
\text { "sterilizing" operations to counter the inflationary impact of its Euro-zone government } \\
\text { bond purchases. Euro Overnight Index Average Rates is likely to be seen as a sign of } \\
\text { growing market confidence by the ECB but suggests it may have more difficulties in } \\
\text { reabsorbing liquidity. }\end{array}$ \\
\hline $3 / 3 / 2011$ & The ECB's Governing Council decides to continue conducting its main refinancing \\
\hline
\end{tabular}




\begin{tabular}{|c|c|}
\hline & ions as fixed-rate tender procedures with full allotment for as long as necessary. \\
\hline $3 / 4 / 2011$ & Greece unveils radical austerity package. \\
\hline $4 / 7 / 2011$ & ECB raises interest rates by 25 basis points. \\
\hline $4 / 8 / 2011$ & $\begin{array}{l}\text { Mr. Dominique Strauss-Kahn, Managing Director of IMF, states IMF has received a } \\
\text { request for financial assistance from the Portuguese authorities and it stood ready to } \\
\text { join the effort, together with our European partners, to help restore growth and } \\
\text { financial stability in Portugal. }\end{array}$ \\
\hline $5 / 18 / 2011$ & Merkel suggests Greece to hold a referendum on its membership of the Euro-zone. \\
\hline $5 / 19 / 2011$ & IMF Executive Board Approves an $€ 26$ billion Extended Arrangement for Portugal. \\
\hline $6 / 24 / 2011$ & $\begin{array}{l}\text { A technical team sent to Athens by Troika tells Greece that the austerity plan falls } \\
\text { short with a } € 5.5 \text { billion "black hole". }\end{array}$ \\
\hline $6 / 27 / 2011$ & Greece is given hope as French banks agree to roll over Greece's debt. \\
\hline $7 / 7 / 2011$ & ECB raises interest rates by 25 basis points. \\
\hline $7 / 8 / 2011$ & $\begin{array}{l}\text { IMF Executive Board Completes Fourth Review Under Stand-By Arrangement for } \\
\text { Greece and Approves } € 3.2 \text { Billion Disbursement. }\end{array}$ \\
\hline $8 / 8 / 2011$ & $\begin{array}{l}\text { ECB says it will buy Italian and Spanish government bonds to try to bring down their } \\
\text { borrowing costs, as concern grows that the debt crisis may spread to the larger } \\
\text { economies of Italy and Spain. }\end{array}$ \\
\hline $8 / 9 / 2011$ & Bailout chip away at France and Germany too. \\
\hline $9 / 15 / 2011$ & Lagarde warns that IMF will hold back loan if Athens fails to act. \\
\hline 9/16/2011 & Spain announces a new, temporary tax on its wealthiest citizens. \\
\hline $9 / 19 / 2011$ & $\begin{array}{l}\text { Greece will seek to persuade its lenders that it deserves another } € 8 \text { bn loan payment in } \\
\text { a pivotal conference call that will pit the Greek finance minister against } \\
\text { representatives from the Troika. }\end{array}$ \\
\hline $9 / 20 / 2011$ & $\begin{array}{l}\text { The sovereign debt crisis continues to unfold in Europe, with every country appearing } \\
\text { to get sucked in. }\end{array}$ \\
\hline $10 / 3 / 2011$ & $\begin{array}{l}\text { Greek government presents } 2012 \text { budget to parliament calling for sharp increase in } \\
\text { taxes and spending cuts. }\end{array}$ \\
\hline $10 / 4 / 2011$ & $\begin{array}{l}\text { Despite government downgrades of its gross domestic product growth forecasts, Mr. } \\
\text { Tremonti pledges that Italy would meet its target of eliminating the budget deficit by } \\
2013 \text {. }\end{array}$ \\
\hline $11 / 18 / 2011$ & $\begin{array}{l}\text { Mario Draghi, President of ECB, declares that the Euro-zone crisis is a crisis in need } \\
\text { of a political solution and the ECB will not bail out anybody. }\end{array}$ \\
\hline $11 / 21 / 2011$ & $\begin{array}{l}\text { Mr. Papademos says that Greek party leaders would have to provide a written } \\
\text { commitment to the adoption and implementation of the measures related to a new } \\
\text { bailout plan for Greece. }\end{array}$ \\
\hline $2 / 8 / 2012$ & Greek bailout talks finally begin. \\
\hline $2 / 9 / 2012$ & Greek bailout deal reached, but Euro-zone Finance Ministers are cautious. \\
\hline $2 / 23 / 2012$ & $\begin{array}{l}\text { Euro-zone growth forecasts are revised down sharply by EC. The EU economy is } \\
\text { projected to stagnate in 2012, while the euro area is set to enter into a mild recession. } \\
\text { Modest growth is predicted to return in the second half of the year. }\end{array}$ \\
\hline $2 / 24 / 2012$ & $\begin{array}{l}\text { Moody's cut credit rating outlook for Germany, the Netherlands and Luxembourg } \\
\text { from stable to negative. }\end{array}$ \\
\hline $3 / 7 / 2012$ & $\begin{array}{l}\text { Tougher rules to prevent a breakdown of securities markets infrastructure is unveiled } \\
\text { by EC. }\end{array}$ \\
\hline $3 / 8 / 2012$ & ECB reactivates eligibility of Greek bonds as collateral. \\
\hline $3 / 19 / 2012$ & EU provides hands-on expertise to help Greece return its economy to growth and job \\
\hline
\end{tabular}




\begin{tabular}{|c|c|}
\hline & creation. \\
\hline $3 / 20 / 2012$ & Greek debt swap triggers massive payouts. \\
\hline $6 / 7 / 2012$ & EC sets to make bank investors, instead of taxpayers, to pay rescue costs. \\
\hline $6 / 8 / 2012$ & $\begin{array}{l}\text { IMF Says Spain's Core Financial System is Resilient, but Important Vulnerabilities } \\
\text { Remain. }\end{array}$ \\
\hline $6 / 15 / 2012$ & $\begin{array}{l}\text { Former UK PM Gordon Brown has warned that France and Italy may need to be } \\
\text { bailed out like Spain because of the unfolding Euro-zone crisis. }\end{array}$ \\
\hline $6 / 18 / 2012$ & Italy has its primary budget surplus. \\
\hline $7 / 23 / 2012$ & The Bank of Spain says that the country is expected to remain in recession until 2014. \\
\hline $7 / 24 / 2012$ & Greek PM says the economy could contract by 7 percent this year. \\
\hline $7 / 26 / 2012$ & $\begin{array}{l}\text { ECB President Mario Draghi says that the ECB, within its mandate, will do "whatever } \\
\text { it takes to preserve the euro". "Believe me, it will be enough", he adds, triggering a } \\
\text { market rally. }\end{array}$ \\
\hline $7 / 27 / 2012$ & $\begin{array}{l}\text { Spain has at last conceded it may need a state bailout and policymakers are } \\
\text { considering writing down Greek debt to their central banks. }\end{array}$ \\
\hline $7 / 30 / 2012$ & $\begin{array}{l}\text { German Chancellor Merkel and Italian PM Monti have agreed to do everything to } \\
\text { protect the Euro-zone and swiftly implement measures agreed by EU leaders in June. }\end{array}$ \\
\hline $7 / 31 / 2012$ & Euro-zone unemployment hits record high. \\
\hline $9 / 12 / 2012$ & German court approves bailout find with conditions. \\
\hline $9 / 13 / 2012$ & IMF warns that Greece will need a third bail-out. \\
\hline $10 / 17 / 2012$ & $\begin{array}{l}\text { Statement by Troika on Greece, discussed with the authorities the set of policies that } \\
\text { could serve as a basis for the completion of the first review of the country’s economic } \\
\text { adjustment program. Greece agrees on most measures in a new } € 13.8 \text { billion package } \\
\text { of spending cuts and tax increases, but disagrees over labor market reforms. }\end{array}$ \\
\hline $10 / 18 / 2012$ & $\begin{array}{l}\text { EU summit takes place. France and Germany will clash over Berlin's attempts to } \\
\text { block using the Euro-zone bailout fund to recapitalize banks. }\end{array}$ \\
\hline $11 / 27 / 2012$ & $\begin{array}{l}\text { Mario Monti finds that Italy's lifestyle and luxury brands are driving exports, but } \\
\text { attracting foreign investment at home is proving much tougher. }\end{array}$ \\
\hline $11 / 28 / 2012$ & $\begin{array}{l}\text { EC unveils plan maps path to full economic, monetary, budgetary and political } \\
\text { integration. }\end{array}$ \\
\hline $12 / 3 / 2012$ & $\begin{array}{l}\text { Greece announces details of plans to spend up to } € 10 \text { billion to buy its own debt at a } \\
\text { steep discount. }\end{array}$ \\
\hline $12 / 4 / 2012$ & $\begin{array}{l}\text { European finance ministers fail to agree on key elements of a plan to establish a } \\
\text { common banking regulator. }\end{array}$ \\
\hline $3 / 8 / 2013$ & $\begin{array}{l}\text { Christine Lagarde states that economic activity in Ireland is still weak, but IMF } \\
\text { expected Ireland's growth to exceed that of most EU countries in } 2013 \text { and the } \\
\text { recovery to gradually gain momentum. }\end{array}$ \\
\hline $4 / 8 / 2013$ & $\begin{array}{l}\text { Mario Monti's caretaker government decides to pay } € 40 \text { billion in arrears owed by the } \\
\text { public administration to the private sector over the next } 12 \text { months. }\end{array}$ \\
\hline $5 / 2 / 2013$ & ECB lowers rates. \\
\hline $5 / 3 / 2013$ & $\begin{array}{l}\text { France has slipped back into recession and will need two more years to bring its } \\
\text { budget deficit under control. }\end{array}$ \\
\hline $6 / 28 / 2013$ & $\begin{array}{l}\text { Ireland has plunged back into recession amid a decline in net exports and a fall in } \\
\text { personal consumption, raising question marks over an economy tipped as the Euro- } \\
\text { zone's best chance of a bailout success story. }\end{array}$ \\
\hline $7 / 11 / 2013$ & $\begin{array}{l}\text { Portugal's President throws the bailout Euro-zone country into disarray after rejecting } \\
\text { a plan to heal a government rift. }\end{array}$ \\
\hline $7 / 12 / 2013$ & Portugal's political crisis deepens. \\
\hline
\end{tabular}




\begin{tabular}{|l|l|}
\hline $8 / 12 / 2013$ & Euro-zone banks need to shed $€ 3.2$ trillion in assets to meet Basel III. \\
\hline $8 / 13 / 2013$ & $\begin{array}{l}\text { GDP figures show that the Euro-zone is finally emerging from its worst recession on } \\
\text { record. }\end{array}$ \\
\hline $11 / 4 / 2013$ & $\begin{array}{l}\text { EC forecasts inflation in the Euro-zone will stay subdued and unemployment will } \\
\text { hover around current record highs for two years, adding to the ECB's dilemma over } \\
\text { how to shelter a nascent economic recovery. }\end{array}$ \\
\hline $11 / 5 / 2013$ & Pressure mounts on ECB following Euro-zone forecasts. \\
\hline $11 / 22 / 2013$ & $\begin{array}{l}\text { ECB's chief economist said the Euro-zone faces deflationary pressures, and the } \\
\text { bank's president Mario Draghi stressed that interest rates must remain low "because } \\
\text { the economy is weak". }\end{array}$ \\
\hline $1 / 21 / 2014$ & $\begin{array}{l}\text { IMF says that there is as high as a one-in-five chance that prices could start to fall in } \\
\text { the Euro-zone. }\end{array}$ \\
\hline $1 / 22 / 2014$ & $\begin{array}{l}\text { The size of the market for "repurchase" contracts declined by 8.2 per cent to } € 5.4 \\
\text { trillion compared with the first six months of the year. }\end{array}$ \\
\hline $4 / 3 / 2014$ & Mario Draghi says ECB will use all methods needed to fight prolonged low inflation. \\
\hline $4 / 4 / 2014$ & Irish Central Bank cuts Growth Outlook. \\
\hline $4 / 15 / 2014$ & $\begin{array}{l}\text { Reza Moghadam, Director of the European Department, said that IMF had the } \\
\text { commitments to ensure that Greece will continue to have sufficient financing and } \\
\text { would meet its obligations. }\end{array}$ \\
\hline $4 / 16 / 2014$ & Euro-zone inflation dropped to its lowest level in more than four years. \\
\hline
\end{tabular}


Table 6A. Results from the aDCC- M-eGARCH model (Perfect Foresight Exchange Rate Expectations)

\begin{tabular}{|c|c|c|c|c|c|c|c|c|c|c|}
\hline & \multicolumn{6}{|c|}{ Mean relation } & \multicolumn{4}{|c|}{ Variance model } \\
\hline & $\mathrm{C}_{\text {籿 }}$ & $c_{66^{\circ}}$ & $\mathrm{C}_{36}$ & $\mathrm{c}_{\text {ศाष }}$ & $\mathrm{r}_{6}$ & $\mathrm{c}_{28}$ & 61 & Q & $\odot$ & $\gamma$ \\
\hline Greece & $\begin{array}{c}7.73 * * * \\
(0.26) \\
\end{array}$ & & $\begin{array}{c}1.45 \\
(1.09)\end{array}$ & $\begin{array}{c}4.88^{* * *} \\
(1.35) \\
\end{array}$ & $\begin{array}{c}1.96^{* * *} \\
(0.38)\end{array}$ & $\begin{array}{c}0.26 \\
(1.68)\end{array}$ & $\begin{array}{c}0.02 \\
(0.07)\end{array}$ & $\begin{array}{c}0.94 * * * \\
(0.06)\end{array}$ & $\begin{array}{l}-0.04 \\
(0.09)\end{array}$ & $\begin{array}{c}1.07 * * * \\
(0.38)\end{array}$ \\
\hline Ireland & $\begin{array}{c}0.65^{* * * *} \\
(0.02)\end{array}$ & $\begin{array}{c}0.04 \\
(0.03)\end{array}$ & & $\begin{array}{c}0.04 \\
(0.08)\end{array}$ & $\begin{array}{l}-0.01 \\
(0.02)\end{array}$ & $\begin{array}{c}0.74 * * * \\
(0.10)\end{array}$ & $\begin{array}{c}0.91 * * * \\
(0.04)\end{array}$ & $\begin{array}{c}0.08 * * \\
(0.04)\end{array}$ & $\begin{array}{c}0.002 * * * \\
(0.0005)\end{array}$ & \\
\hline Portugal & $\begin{array}{c}2.19^{* * * *} \\
(0.04)\end{array}$ & $\begin{array}{c}0.21 \\
(0.45)\end{array}$ & $\begin{array}{c}2.10 * * * \\
(0.07)\end{array}$ & & $\begin{array}{c}1.02 * * * \\
(0.26)\end{array}$ & $\begin{array}{c}0.55 \\
(0.45)\end{array}$ & $\begin{array}{c}0.68^{* * * *} \\
(0.10)\end{array}$ & $\begin{array}{l}0.31^{* *} \\
(0.12)\end{array}$ & $\begin{array}{c}0.01 \\
(0.01)\end{array}$ & \\
\hline Spain & $\begin{array}{c}1.36^{* * * *} \\
(0.01)\end{array}$ & $\begin{array}{c}0.02 \\
(0.24)\end{array}$ & $\begin{array}{c}0.76^{* * * *} \\
(0.06) \\
\end{array}$ & $\begin{array}{c}0.54 * * * \\
(0.19) \\
\end{array}$ & & $\begin{array}{c}0.34 \\
(0.36) \\
\end{array}$ & $\begin{array}{c}-0.0002 \\
(0.02) \\
\end{array}$ & $\begin{array}{c}0.95^{* * *} \\
(0.01) \\
\end{array}$ & $\begin{array}{c}-0.19 * * * \\
(0.04) \\
\end{array}$ & $\begin{array}{c}1.00^{* * * *} \\
(0.23)\end{array}$ \\
\hline Italy & $\begin{array}{c}1.38 * * * \\
(0.01)\end{array}$ & $\begin{array}{c}0.39 * * * \\
(0.02)\end{array}$ & $\begin{array}{c}0.26 * * * \\
(0.004)\end{array}$ & $\begin{array}{c}1.12 * * * \\
(0.02)\end{array}$ & $\begin{array}{c}0.25 * * * \\
(0.10)\end{array}$ & & $\begin{array}{c}0.03 \\
(0.02)\end{array}$ & $\begin{array}{c}0.93 * * * \\
(0.02)\end{array}$ & $\begin{array}{c}-0.25 * * * \\
(0.05)\end{array}$ & $\begin{array}{c}1.15^{* * * *} \\
(0.17)\end{array}$ \\
\hline France & $\begin{array}{c}0.35^{* * * *} \\
(0.003)\end{array}$ & $\begin{array}{c}-0.47 * * * \\
(0.01)\end{array}$ & $\begin{array}{c}0.02 * * * \\
(0.003)\end{array}$ & $\begin{array}{c}0.11 * * * \\
(0.004)\end{array}$ & $\begin{array}{c}0.29 * * * \\
(0.01)\end{array}$ & $\begin{array}{c}0.01 * * * \\
(0.004)\end{array}$ & $\begin{array}{c}0.03 \\
(0.02)\end{array}$ & $\begin{array}{c}0.95^{* * *} \\
(0.01)\end{array}$ & $\begin{array}{c}-0.28 * * * \\
(0.06)\end{array}$ & $\begin{array}{c}0.85^{* * * *} \\
(0.06)\end{array}$ \\
\hline Netherlands & $\begin{array}{c}0.21 * * * \\
(0.004) \\
\end{array}$ & $\begin{array}{l}-0.001 \\
(0.03)\end{array}$ & $\begin{array}{c}0.07 * * * \\
(0.01) \\
\end{array}$ & $\begin{array}{c}0.01 \\
(0.02) \\
\end{array}$ & $\begin{array}{l}-0.01 \\
(0.01) \\
\end{array}$ & $\begin{array}{c}0.06^{* * *} \\
(0.01) \\
\end{array}$ & $\begin{array}{c}0.01 \\
(0.02)\end{array}$ & $\begin{array}{c}0.88^{* * *} \\
(0.02) \\
\end{array}$ & $\begin{array}{c}-0.78 * * * \\
(0.13) \\
\end{array}$ & $\begin{array}{c}1.20^{* * * *} \\
(0.10)\end{array}$ \\
\hline Belgium & $\begin{array}{c}2.42 * * * \\
(0.01)\end{array}$ & $\begin{array}{c}0.22 * * * \\
(0.01)\end{array}$ & $\begin{array}{c}0.80 * * * \\
(0.01)\end{array}$ & $\begin{array}{c}0.94 * * * \\
(0.01)\end{array}$ & $\begin{array}{c}0.07 * * * \\
(0.002)\end{array}$ & $\begin{array}{c}-0.04 * * * \\
(0.004)\end{array}$ & $\begin{array}{l}-0.04 * \\
(0.02)\end{array}$ & $\begin{array}{c}0.93 * * * \\
(0.01)\end{array}$ & $\begin{array}{c}-0.23 * * * \\
(0.03)\end{array}$ & $\begin{array}{c}1.22^{* * * *} \\
(0.11)\end{array}$ \\
\hline Poland & $\begin{array}{c}2.44 * * * \\
(0.03)\end{array}$ & $\begin{array}{c}0.48 * * * \\
(0.06)\end{array}$ & $\begin{array}{c}0.55^{* * * *} \\
(0.03)\end{array}$ & $\begin{array}{c}0.09^{* * *} \\
(0.02)\end{array}$ & $\begin{array}{c}-0.05^{* *} \\
(0.02)\end{array}$ & $\begin{array}{c}0.34 * * * \\
(0.06)\end{array}$ & $\begin{array}{l}-0.01^{*} \\
(0.01)\end{array}$ & $\begin{array}{c}0.99 * * * \\
(0.01)\end{array}$ & $\begin{array}{c}-0.02 * * \\
(0.01)\end{array}$ & $\begin{array}{c}0.17^{* * * *} \\
(0.03)\end{array}$ \\
\hline $\begin{array}{l}\text { Czech } \\
\text { Republic }\end{array}$ & $\begin{array}{c}0.31 * * * \\
(0.01)\end{array}$ & $\begin{array}{c}0.39 * * * \\
(0.12)\end{array}$ & $\begin{array}{c}0.46^{* * * *} \\
(0.04)\end{array}$ & $\begin{array}{l}0.18^{*} \\
(0.10)\end{array}$ & $\begin{array}{c}0.17 * * * \\
(0.05)\end{array}$ & $\begin{array}{l}0.09^{* *} \\
(0.04)\end{array}$ & $\begin{array}{c}0.01 \\
(0.01)\end{array}$ & $\begin{array}{c}0.98^{* * *} \\
(0.01)\end{array}$ & $\begin{array}{c}-0.06^{* * *} * \\
(0.02)\end{array}$ & $\begin{array}{c}0.39 * * * \\
(0.05)\end{array}$ \\
\hline Hungary & $\begin{array}{c}3.33^{* * * *} \\
(0.05)\end{array}$ & $\begin{array}{c}0.48^{* *} \\
(0.22)\end{array}$ & $\begin{array}{c}0.97 * * * \\
(0.06)\end{array}$ & $\begin{array}{c}0.10 \\
(0.08)\end{array}$ & $\begin{array}{c}1.34 * * * \\
(0.08)\end{array}$ & $\begin{array}{c}0.59 * * * \\
(0.17)\end{array}$ & $\begin{array}{l}-0.002 \\
(0.01)\end{array}$ & $\begin{array}{c}0.97 * * * \\
(0.01)\end{array}$ & $\begin{array}{c}-0.01^{* *} \\
(0.01)\end{array}$ & $\begin{array}{c}0.28 * * * * \\
(0.05)\end{array}$ \\
\hline Switzerland & $\begin{array}{c}-0.64 * * * \\
(0.01)\end{array}$ & $\begin{array}{c}-0.07 * * * \\
(0.02)\end{array}$ & $\begin{array}{l}-0.03 \\
(0.04)\end{array}$ & $\begin{array}{c}-0.14 * * * \\
(0.04)\end{array}$ & $\begin{array}{c}-0.07 * * * \\
(0.01)\end{array}$ & $\begin{array}{c}-0.16^{* * *} \\
(0.03)\end{array}$ & $\begin{array}{c}-0.01 * * \\
(0.01)\end{array}$ & $\begin{array}{c}0.99 * * * \\
(0.002)\end{array}$ & $\begin{array}{c}-0.03 * * * \\
(0.01)\end{array}$ & $\begin{array}{c}0.19 * * * \\
(0.03)\end{array}$ \\
\hline U.K. & $\begin{array}{c}1.06^{* * * *} \\
(0.03)\end{array}$ & $\begin{array}{l}0.13^{* *} \\
(0.06)\end{array}$ & $\begin{array}{c}-0.46^{* * *} \\
(0.11)\end{array}$ & $\begin{array}{l}-0.11 \\
(0.09)\end{array}$ & $\begin{array}{l}-0.38^{*} \\
(0.21)\end{array}$ & $\begin{array}{l}-0.15 \\
(0.15)\end{array}$ & $\begin{array}{l}0.0001 \\
(0.01)\end{array}$ & $\begin{array}{c}0.97 * * * \\
(0.01)\end{array}$ & $\begin{array}{l}-0.03^{*} \\
(0.02)\end{array}$ & $\begin{array}{c}0.13 * * * * \\
(0.04)\end{array}$ \\
\hline Sweden & $\begin{array}{c}0.37 * * * \\
(0.02)\end{array}$ & $\begin{array}{c}0.05 \\
(0.05)\end{array}$ & $\begin{array}{c}-0.18 * * * \\
(0.03)\end{array}$ & $\begin{array}{c}-0.20 * * * \\
(0.05)\end{array}$ & $\begin{array}{l}-0.01 \\
(0.03)\end{array}$ & $\begin{array}{c}-0.15 * * * \\
(0.05)\end{array}$ & $\begin{array}{l}-0.02 \\
(0.02)\end{array}$ & $\begin{array}{c}0.92 * * * \\
(0.04)\end{array}$ & $\begin{array}{l}-0.12 * \\
(0.07)\end{array}$ & $\begin{array}{c}0.12 * * * \\
(0.04)\end{array}$ \\
\hline
\end{tabular}

Note: $* * * * *$ and $*$ indicate the significant levels of $1 \%, 5 \%$ and $10 \%$ respectively.

Diagnostics: $\mathrm{LL}=-2484.55, !_{1}=0.09(0.004), ! !_{2}=0.90(0.005)$ and $! !_{3}=0.01(0.002), \mathrm{AIC}=3.13, \mathrm{BIC}=3.90, \mathrm{H}-\mathrm{Q}=3.41$

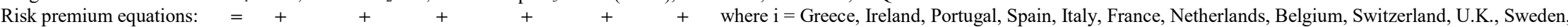

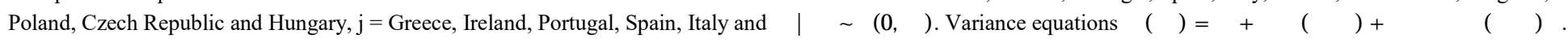


Table 6B Results from the Quantile Model (with Perfect Foresight Exchange Rate Expectations)

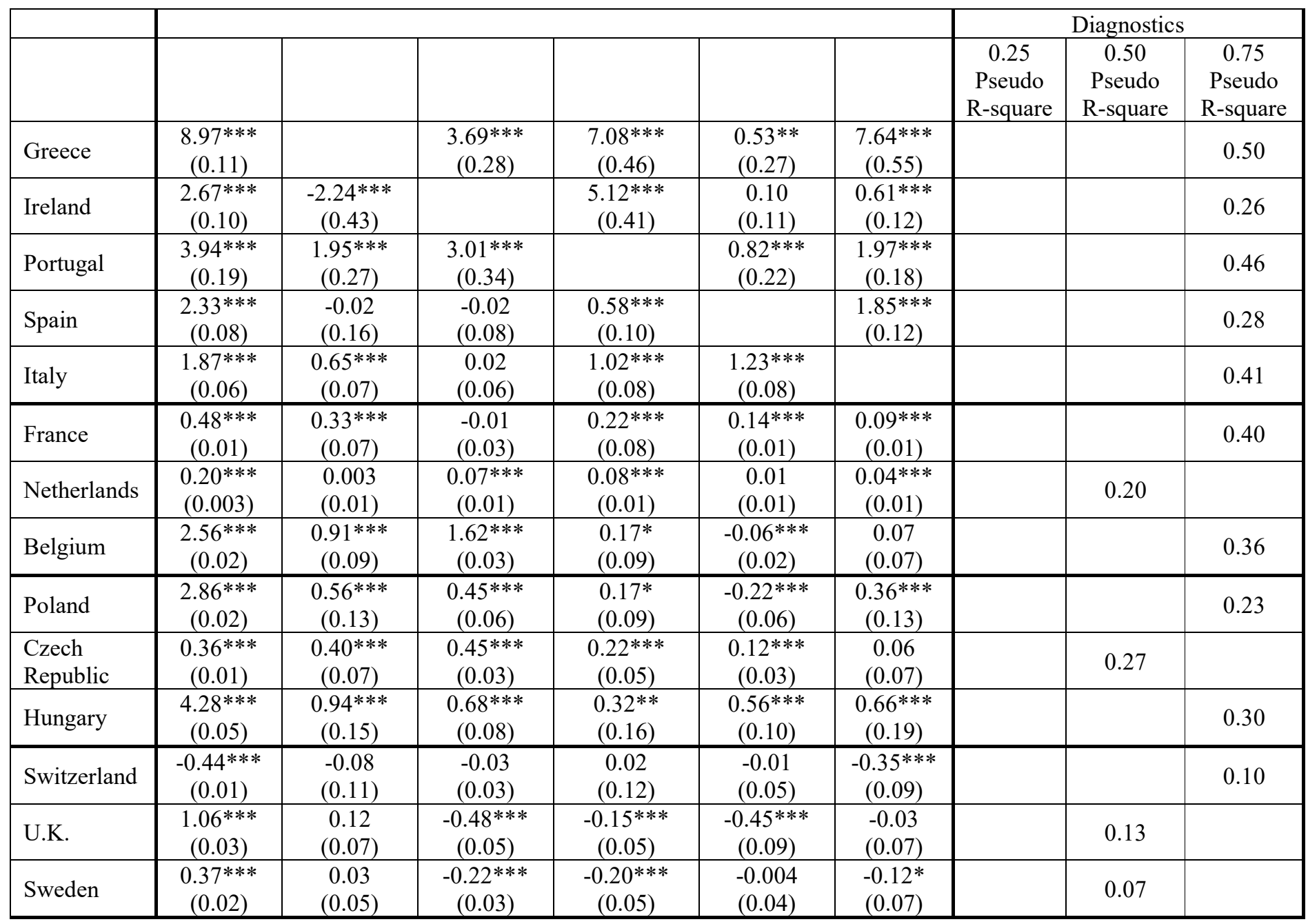

Note: $* * *, * *$ and $*$ indicate the significant levels of $1 \%, 5 \%$ and $10 \%$ respectively.

Number of observations $=1746$

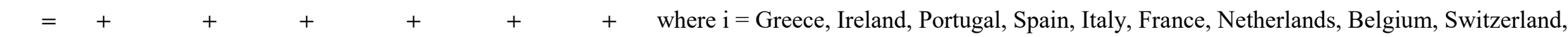

U.K., Sweden, Poland, Czech Republic and Hungary 
Table 7A. Results from the aDCC-M-eGARCH-NAGARCH model (Perfect Foresight Exchange Rate Expectations and weekly data)

\begin{tabular}{|c|c|c|c|c|c|c|c|c|c|c|}
\hline & \multicolumn{6}{|c|}{ Mean relation } & \multicolumn{4}{|c|}{ Variance model } \\
\hline & $C_{\text {积 }}$ & $c_{66^{\circ}}$ & $\mathrm{C}_{3 \infty}$ & $c_{\text {бाม }}$ & $\mathrm{c}_{61}$ & $c_{28}$ & ๔ & Q & ๑ & $\gamma$ \\
\hline Greece & $\begin{array}{c}7.72 * * * \\
(0.10)\end{array}$ & & $\begin{array}{c}1.54 * * * \\
(0.05)\end{array}$ & $\begin{array}{c}4.10^{* * *} \\
(0.15)\end{array}$ & $\begin{array}{c}2.93 * * * \\
(0.13)\end{array}$ & $\begin{array}{l}-0.28 * \\
(0.15)\end{array}$ & $\begin{array}{c}0.08 \\
(0.06)\end{array}$ & $\begin{array}{c}0.86^{* * *} \\
(0.03)\end{array}$ & $\begin{array}{c}0.07 \\
(0.07)\end{array}$ & $\begin{array}{c}1.62 * * * \\
(0.15)\end{array}$ \\
\hline Ireland & $\begin{array}{c}1.09^{* * *} \\
(0.01)\end{array}$ & $\begin{array}{c}-1.27 * * * \\
(0.05)\end{array}$ & & $\begin{array}{c}-1.25 * * * \\
(0.08)\end{array}$ & $\begin{array}{c}1.55^{* * *} \\
(0.08)\end{array}$ & $\begin{array}{c}1.07 * * * \\
(0.10)\end{array}$ & $\begin{array}{c}0.11 \\
(0.08)\end{array}$ & $\begin{array}{c}0.86^{* * *} \\
(0.04)\end{array}$ & $\begin{array}{c}-0.21 * * \\
(0.09)\end{array}$ & $\begin{array}{c}2.22 * * * \\
(0.28)\end{array}$ \\
\hline Portugal & $\begin{array}{c}2.20 * * * \\
(0.06)\end{array}$ & $\begin{array}{c}1.07 * * * \\
(0.19) \\
\end{array}$ & $\begin{array}{c}1.75^{* * *} \\
(0.13) \\
\end{array}$ & & $\begin{array}{c}0.55^{* * *} \\
(0.14) \\
\end{array}$ & $\begin{array}{l}-0.16 \\
(0.17) \\
\end{array}$ & $\begin{array}{c}0.82 * * * \\
(0.08)\end{array}$ & $\begin{array}{c}0.17 * * * \\
(0.06) \\
\end{array}$ & $\begin{array}{l}0.03 * \\
(0.01)\end{array}$ & \\
\hline Spain & $\begin{array}{c}1.36^{* * *} \\
(0.01)\end{array}$ & $\begin{array}{c}-0.04 * * * \\
(0.001)\end{array}$ & $\begin{array}{c}0.79 * * * \\
(0.02)\end{array}$ & $\begin{array}{c}-0.16^{* * * *} \\
(0.01)\end{array}$ & & $\begin{array}{c}0.07 * * * \\
(0.001)\end{array}$ & $\begin{array}{c}0.11 \\
(0.19)\end{array}$ & $\begin{array}{c}0.85^{* * *} \\
(0.09)\end{array}$ & $\begin{array}{l}-0.41^{*} \\
(0.23)\end{array}$ & $\begin{array}{c}1.71 * * * \\
(0.49)\end{array}$ \\
\hline Italy & $\begin{array}{c}1.35^{* * *} \\
(0.01)\end{array}$ & $\begin{array}{c}-0.12 * * * \\
(0.05)\end{array}$ & $\begin{array}{c}0.29 * * * \\
(0.01)\end{array}$ & $\begin{array}{l}-0.002 \\
(0.01)\end{array}$ & $\begin{array}{c}-0.54 * * * \\
(0.02)\end{array}$ & & $\begin{array}{c}0.12 \\
(0.09)\end{array}$ & $\begin{array}{c}0.85^{* * *} \\
(0.04)\end{array}$ & $\begin{array}{c}-0.42^{* * *} \\
(0.10)\end{array}$ & $\begin{array}{c}1.61^{* * * *} \\
(0.24)\end{array}$ \\
\hline France & $\begin{array}{l}0.35 * * * \\
(0.004)\end{array}$ & $\begin{array}{c}0.32 * * * \\
(0.03)\end{array}$ & $\begin{array}{c}0.02 * * * \\
(0.01)\end{array}$ & $\begin{array}{c}0.12 * * * \\
(0.02)\end{array}$ & $\begin{array}{c}0.27 * * * \\
(0.01)\end{array}$ & $\begin{array}{c}0.07 * * * \\
(0.01)\end{array}$ & $\begin{array}{l}-0.02 \\
(0.05)\end{array}$ & $\begin{array}{c}0.86^{* * *} \\
(0.04)\end{array}$ & $\begin{array}{c}-0.67 * * * \\
(0.16)\end{array}$ & $\begin{array}{c}1.31 * * * \\
(0.11)\end{array}$ \\
\hline Netherlands & $\begin{array}{l}0.19 * * * \\
(0.001)\end{array}$ & $\begin{array}{c}0.01 \\
(0.01) \\
\end{array}$ & $\begin{array}{c}0.09 * * * \\
(0.001) \\
\end{array}$ & $\begin{array}{c}0.03 * * * \\
(0.01) \\
\end{array}$ & $\begin{array}{c}0.01 \\
(0.01)\end{array}$ & $\begin{array}{c}0.05^{* * * *} \\
(0.01) \\
\end{array}$ & $\begin{array}{c}0.06 \\
(0.10) \\
\end{array}$ & $\begin{array}{c}0.66^{* * * *} \\
(0.04) \\
\end{array}$ & $\begin{array}{c}-2.03 * * * \\
(0.18) \\
\end{array}$ & $\begin{array}{c}2.15^{* * * *} \\
(0.22)\end{array}$ \\
\hline Belgium & $\begin{array}{c}2.50 * * * \\
(0.01)\end{array}$ & $\begin{array}{c}0.40 * * * \\
(0.01)\end{array}$ & $\begin{array}{c}0.28 * * * \\
(0.04)\end{array}$ & $\begin{array}{c}0.77 * * * \\
(0.01)\end{array}$ & $\begin{array}{l}-0.05^{*} \\
(0.03)\end{array}$ & $\begin{array}{l}0.001 \\
(0.03)\end{array}$ & $\begin{array}{l}-0.13^{*} \\
(0.07)\end{array}$ & $\begin{array}{c}0.85^{* * *} \\
(0.04)\end{array}$ & $\begin{array}{c}-0.42 * * * \\
(0.05)\end{array}$ & $\begin{array}{c}2.22 * * * \\
(0.17)\end{array}$ \\
\hline Poland & $\begin{array}{c}2.31 * * * \\
(0.06)\end{array}$ & $\begin{array}{c}0.46^{* * *} \\
(0.17)\end{array}$ & $\begin{array}{c}0.70 * * * \\
(0.07)\end{array}$ & $\begin{array}{l}-0.07 \\
(0.07)\end{array}$ & $\begin{array}{c}0.03 \\
(0.06)\end{array}$ & $\begin{array}{c}0.39 * * * \\
(0.14)\end{array}$ & $\begin{array}{c}0.06 \\
(0.05)\end{array}$ & $\begin{array}{c}0.86^{* * *} \\
(0.05)\end{array}$ & $\begin{array}{c}-0.30 * * * \\
(0.10)\end{array}$ & $\begin{array}{c}0.57 * * * \\
(0.09)\end{array}$ \\
\hline $\begin{array}{l}\text { Czech } \\
\text { Republic }\end{array}$ & $\begin{array}{c}0.29 * * * \\
(0.01)\end{array}$ & $\begin{array}{c}0.44 * * * \\
(0.09)\end{array}$ & $\begin{array}{c}0.47 * * * \\
(0.01)\end{array}$ & $\begin{array}{l}0.15^{*} \\
(0.08)\end{array}$ & $\begin{array}{c}0.16^{* * *} \\
(0.04)\end{array}$ & $\begin{array}{l}0.13^{* *} \\
(0.06)\end{array}$ & $\begin{array}{c}0.03 \\
(0.04)\end{array}$ & $\begin{array}{c}0.91 * * * \\
(0.02)\end{array}$ & $\begin{array}{c}-0.29^{* * *} \\
(0.07)\end{array}$ & $\begin{array}{c}0.70^{* * * *} \\
(0.09)\end{array}$ \\
\hline Hungary & $\begin{array}{c}3.32 * * * \\
(0.05)\end{array}$ & $\begin{array}{c}0.59 \\
(0.372)\end{array}$ & $\begin{array}{c}0.95^{* * *} \\
(0.21)\end{array}$ & $\begin{array}{l}-0.05 \\
(0.23)\end{array}$ & $\begin{array}{c}1.54 * * * \\
(0.34)\end{array}$ & $\begin{array}{c}0.40 \\
(0.35)\end{array}$ & $\begin{array}{c}0.04 \\
(0.07)\end{array}$ & $\begin{array}{c}0.80 * * * \\
(0.08)\end{array}$ & $\begin{array}{c}-0.18^{* *} \\
(0.08)\end{array}$ & $\begin{array}{c}1.04 * * * \\
(0.36)\end{array}$ \\
\hline Switzerland & $\begin{array}{c}-0.68 * * * \\
(0.04)\end{array}$ & $\begin{array}{c}-0.04 * * \\
(0.02)\end{array}$ & $\begin{array}{l}-0.03 \\
(0.05)\end{array}$ & $\begin{array}{c}-0.23 * * * \\
(0.04)\end{array}$ & $\begin{array}{c}-0.11 * * * \\
(0.02)\end{array}$ & $\begin{array}{c}-0.11 * * * \\
(0.02)\end{array}$ & $\begin{array}{l}-0.03 \\
(0.04)\end{array}$ & $\begin{array}{c}0.93 * * * \\
(0.02)\end{array}$ & $\begin{array}{c}-0.21 * * * \\
(0.07)\end{array}$ & $\begin{array}{c}0.65^{* * * *} \\
(0.11)\end{array}$ \\
\hline U.K. & $\begin{array}{c}1.09 * * * \\
(0.04)\end{array}$ & $\begin{array}{c}0.23 \\
(0.19)\end{array}$ & $\begin{array}{c}-0.49 * * * \\
(0.13)\end{array}$ & $\begin{array}{l}-0.13 \\
(0.12)\end{array}$ & $\begin{array}{c}-0.55^{* *} \\
(0.22) \\
\end{array}$ & $\begin{array}{l}-0.01 \\
(0.23)\end{array}$ & $\begin{array}{l}-0.04 \\
(0.05) \\
\end{array}$ & $\begin{array}{c}0.72 * * * \\
(0.10) \\
\end{array}$ & $\begin{array}{c}-0.57 * * * \\
(0.19)\end{array}$ & $\begin{array}{c}0.57 * * * \\
(0.20) \\
\end{array}$ \\
\hline Sweden & $\begin{array}{c}0.41^{* * *} \\
(0.03)\end{array}$ & $\begin{array}{c}0.03 \\
(0.11)\end{array}$ & $\begin{array}{c}-0.19 * * * \\
(0.04)\end{array}$ & $\begin{array}{c}-0.23 * * \\
(0.09)\end{array}$ & $\begin{array}{l}-0.01 \\
(0.07)\end{array}$ & $\begin{array}{l}-0.12 * \\
(0.07)\end{array}$ & $\begin{array}{l}-0.13^{*} \\
(0.08)\end{array}$ & $\begin{array}{c}0.74 * * * \\
(0.12)\end{array}$ & $\begin{array}{c}-0.73 * * \\
(0.33)\end{array}$ & $\begin{array}{c}0.14 \\
(0.10)\end{array}$ \\
\hline Japan & $\begin{array}{c}-0.29 * * * \\
(0.01)\end{array}$ & $\begin{array}{c}-0.06^{* * *} \\
(0.02)\end{array}$ & $\begin{array}{c}-0.45 * * * \\
(0.04)\end{array}$ & $\begin{array}{c}0.13^{* * *} \\
(0.004)\end{array}$ & $\begin{array}{c}-0.41 * * * \\
(0.02)\end{array}$ & $\begin{array}{l}0.02 * * * \\
(0.0003)\end{array}$ & $\begin{array}{l}-0.01 \\
(0.09)\end{array}$ & $\begin{array}{c}0.90^{* * *} \\
(0.04)\end{array}$ & $\begin{array}{c}-0.36^{* * *} \\
(0.13)\end{array}$ & $\begin{array}{c}1.44 * * * \\
(0.19)\end{array}$ \\
\hline U.S. & $\begin{array}{c}1.04 * * * \\
(0.004) \\
\end{array}$ & $\begin{array}{c}0.21 * * * \\
(0.004)\end{array}$ & $\begin{array}{c}-0.74 * * * \\
(0.01) \\
\end{array}$ & $\begin{array}{c}-0.05 * * * \\
(0.001) \\
\end{array}$ & $\begin{array}{c}-0.74 * * * \\
(0.01) \\
\end{array}$ & $\begin{array}{c}-0.02 * * * \\
(0.0004) \\
\end{array}$ & $\begin{array}{c}0.09 \\
(0.06) \\
\end{array}$ & $\begin{array}{c}0.87 * * * \\
(0.04) \\
\end{array}$ & $\begin{array}{c}-0.50 * * * \\
(0.13)\end{array}$ & $\begin{array}{c}1.76^{* * * *} \\
(0.22) \\
\end{array}$ \\
\hline
\end{tabular}

Note: ***,** and * indicate the significant levels of $1 \%, 5 \%$ and $10 \%$ respectively

Diagnostics: $\mathrm{LL}=-154.18, !_{1}=0.28(0.03), !_{2}=0.56(0.06)$ and $!_{3}=0.00(0.01), \mathrm{AIC}=2.52, \mathrm{BIC}=5.76, \mathrm{H}-\mathrm{Q}=3.81$

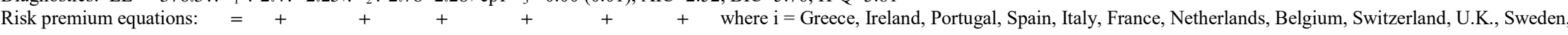

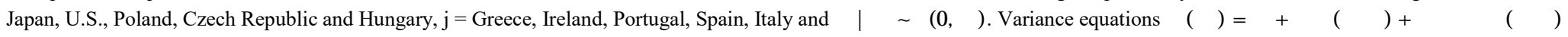


Table 7B. Results from the Quantile Model (Perfect Foresight Exchange Rate Expectations and weekly data)

\begin{tabular}{|c|c|c|c|c|c|c|c|c|c|}
\hline & & & & & & & \multicolumn{3}{|c|}{ Diagnostics } \\
\hline & 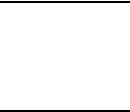 & $\mathrm{C}_{86^{\circ}}$ & $\mathrm{C}_{36^{\circ}}$ & $\mathrm{C}_{\text {ศ๘ }}$ & त ๘ & $\mathrm{C}_{28}$ & $\begin{array}{c}0.25 \\
\text { Pseudo } \\
\text { R-square }\end{array}$ & $\begin{array}{c}0.50 \\
\text { Pseudo } \\
\text { R-square }\end{array}$ & $\begin{array}{c}0.75 \\
\text { Pseudo } \\
\text { R-square }\end{array}$ \\
\hline Greece & $\begin{array}{c}8.83 * * * \\
(0.20)\end{array}$ & & $\begin{array}{c}3.76 * * * \\
(0.61)\end{array}$ & $\begin{array}{c}7.21 * * * \\
(1.78)\end{array}$ & $\begin{array}{c}0.61 \\
(1.92)\end{array}$ & $\begin{array}{c}7.38 * * * \\
(2.22)\end{array}$ & & & 0.50 \\
\hline Ireland & $\begin{array}{c}2.58^{* * *} \\
(0.22)\end{array}$ & $\begin{array}{c}-3.34 * * * \\
(0.56)\end{array}$ & & $\begin{array}{c}6.08 * * * \\
(0.48)\end{array}$ & $\begin{array}{c}0.13 \\
(0.22)\end{array}$ & $\begin{array}{c}0.71^{* * *} \\
(0.19)\end{array}$ & & & 0.27 \\
\hline Portugal & $\begin{array}{c}3.85^{* * *} \\
(0.34) \\
\end{array}$ & $\begin{array}{c}1.97 * * * \\
(0.66)\end{array}$ & $\begin{array}{c}3.03 * * * \\
(0.64) \\
\end{array}$ & & $\begin{array}{c}0.97 \\
(0.88) \\
\end{array}$ & $\begin{array}{l}1.94 * * \\
(0.91) \\
\end{array}$ & & & 0.46 \\
\hline Spain & $\begin{array}{c}2.27 * * * \\
(0.20)\end{array}$ & $\begin{array}{l}-0.20 \\
(0.28)\end{array}$ & $\begin{array}{c}0.10 \\
(0.22)\end{array}$ & $\begin{array}{c}0.41 * * \\
(0.20)\end{array}$ & & $\begin{array}{c}2.04 * * * \\
(0.20)\end{array}$ & & & 0.29 \\
\hline Italy & $\begin{array}{c}1.81^{* * *} \\
(0.18)\end{array}$ & $\begin{array}{c}0.59 * * * \\
(0.18)\end{array}$ & $\begin{array}{c}0.02 \\
(0.15) \\
\end{array}$ & $\begin{array}{c}1.13 * * * \\
(0.15)\end{array}$ & $\begin{array}{c}1.33 * * * \\
(0.15) \\
\end{array}$ & & & & 0.42 \\
\hline France & $\begin{array}{c}0.48^{* * *} \\
(0.02)\end{array}$ & $\begin{array}{c}0.32 * * * \\
(0.11)\end{array}$ & $\begin{array}{l}-0.03 \\
(0.06)\end{array}$ & $\begin{array}{c}0.24 * * \\
(0.11)\end{array}$ & $\begin{array}{c}0.15^{* * * *} \\
(0.02)\end{array}$ & $\begin{array}{l}0.08^{*} \\
(0.04)\end{array}$ & & & 0.41 \\
\hline Netherlands & $\begin{array}{c}0.20 * * * \\
(0.01) \\
\end{array}$ & $\begin{array}{l}-0.01 \\
(0.03) \\
\end{array}$ & $\begin{array}{c}0.07 * * * \\
(0.02)\end{array}$ & $\begin{array}{c}0.09 * * * \\
(0.02) \\
\end{array}$ & $\begin{array}{l}-0.002 \\
(0.02) \\
\end{array}$ & $\begin{array}{c}0.05 * * \\
(0.02) \\
\end{array}$ & & 0.21 & \\
\hline Belgium & $\begin{array}{c}2.55^{* * *} \\
(0.04)\end{array}$ & $\begin{array}{c}1.01^{* * *} \\
(0.25)\end{array}$ & $\begin{array}{c}1.64 * * * \\
(0.07)\end{array}$ & $\begin{array}{c}0.18 \\
(0.23)\end{array}$ & $\begin{array}{l}-0.06 \\
(0.18)\end{array}$ & $\begin{array}{l}-0.03 \\
(0.24)\end{array}$ & & & 0.37 \\
\hline Poland & $\begin{array}{c}2.80^{* * * *} \\
(0.04)\end{array}$ & $\begin{array}{l}0.36^{*} \\
(0.20)\end{array}$ & $\begin{array}{c}0.39 * * * \\
(0.06)\end{array}$ & $\begin{array}{c}0.21 \\
(0.19)\end{array}$ & $\begin{array}{c}-0.34 * * * \\
(0.11)\end{array}$ & $\begin{array}{c}0.53 * * * \\
(0.15)\end{array}$ & & & 0.35 \\
\hline $\begin{array}{l}\text { Czech } \\
\text { Republic }\end{array}$ & $\begin{array}{c}0.38^{* * * *} \\
(0.02)\end{array}$ & $\begin{array}{c}0.46^{* * * *} \\
(0.08)\end{array}$ & $\begin{array}{c}0.45^{* * *} \\
(0.05)\end{array}$ & $\begin{array}{l}0.17^{*} \\
(0.10)\end{array}$ & $\begin{array}{c}0.09 \\
(0.08) \\
\end{array}$ & $\begin{array}{c}0.06 \\
(0.12) \\
\end{array}$ & & 0.36 & \\
\hline Hungary & $\begin{array}{c}4.25^{* * *} \\
(0.07) \\
\end{array}$ & $\begin{array}{c}0.90 \\
(0.64) \\
\end{array}$ & $\begin{array}{c}0.52 * * \\
(0.26) \\
\end{array}$ & $\begin{array}{c}0.48 \\
(0.65) \\
\end{array}$ & $\begin{array}{c}0.52^{* * * *} \\
(0.14) \\
\end{array}$ & $\begin{array}{c}0.77 * * * \\
(0.26) \\
\end{array}$ & & & 0.38 \\
\hline Switzerland & $\begin{array}{c}-0.83 * * * \\
(0.02) \\
\end{array}$ & $\begin{array}{l}-0.03 \\
(0.12) \\
\end{array}$ & $\begin{array}{c}-0.34 * * * \\
(0.07) \\
\end{array}$ & $\begin{array}{c}-0.21^{* *} \\
(0.10) \\
\end{array}$ & $\begin{array}{c}-0.16^{* *} \\
(0.07) \\
\end{array}$ & $\begin{array}{c}0.05 \\
(0.11) \\
\end{array}$ & 0.17 & & \\
\hline U.K. & $\begin{array}{c}1.08 * * * \\
(0.04)\end{array}$ & $\begin{array}{c}0.08 \\
(0.21)\end{array}$ & $\begin{array}{c}-0.59^{* * *} \\
(0.05)\end{array}$ & $\begin{array}{c}0.01 \\
(0.18)\end{array}$ & $\begin{array}{c}-0.41^{* *} \\
(0.18)\end{array}$ & $\begin{array}{l}-0.16 \\
(0.28)\end{array}$ & & 0.27 & \\
\hline Sweden & $\begin{array}{c}0.55^{* * * *} \\
(0.02)\end{array}$ & $\begin{array}{c}0.06 \\
(0.24)\end{array}$ & $\begin{array}{c}-0.22 * * * \\
(0.06)\end{array}$ & $\begin{array}{l}-0.14 \\
(0.12)\end{array}$ & $\begin{array}{l}-0.06 \\
(0.07)\end{array}$ & $\begin{array}{l}-0.16 \\
(0.24)\end{array}$ & & & 0.17 \\
\hline Japan & $\begin{array}{c}-1.12^{* * *} \\
(0.03)\end{array}$ & $\begin{array}{c}-1.13 * * * \\
(0.38)\end{array}$ & $\begin{array}{c}-0.77 * * * \\
(0.09)\end{array}$ & $\begin{array}{c}0.07 \\
(0.10)\end{array}$ & $\begin{array}{c}0.19 \\
(0.53)\end{array}$ & $\begin{array}{c}0.17 \\
(0.61)\end{array}$ & 0.18 & & \\
\hline U.S. & $\begin{array}{c}1.54 * * * \\
(0.01)\end{array}$ & $\begin{array}{c}0.03 \\
(0.37) \\
\end{array}$ & $\begin{array}{c}-0.52 * * * \\
(0.18) \\
\end{array}$ & $\begin{array}{l}-0.18 \\
(0.47) \\
\end{array}$ & $\begin{array}{l}-0.12 \\
(0.43) \\
\end{array}$ & $\begin{array}{l}-0.71 \\
(0.51) \\
\end{array}$ & & & 0.37 \\
\hline
\end{tabular}

Note: $* * *, * *$ and $*$ indicate the significant levels of $1 \%, 5 \%$ and $10 \%$ respectively.

Number of observations $=359$

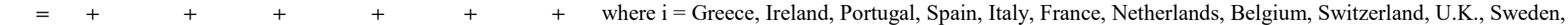

Japan, U.S., Poland, Czech Republic and Hungary 
Table 8A. Estimation Results from the aDCC- M-eGARCH model for Greec and Ireland (with Static Exchange Rate Expectations)

\begin{tabular}{|c|c|c|c|c|c|c|c|}
\hline & \multicolumn{3}{|c|}{ Mean relation } & \multicolumn{4}{|c|}{ Variance model } \\
\hline & $C_{\text {隹 }}$ & $C_{866^{\circ}}$ & $\mathrm{C}_{30^{\circ}}$ & ๔ી & Q & ๑ & $\gamma$ \\
\hline Greece & $\begin{array}{c}7.72 * * * \\
(0.03)\end{array}$ & & $\begin{array}{c}1.54 * * * \\
(0.09)\end{array}$ & $\begin{array}{l}0.02 * \\
(0.01)\end{array}$ & $\begin{array}{c}0.95 * * * \\
(0.01)\end{array}$ & $\begin{array}{c}-0.07 * * * \\
(0.02)\end{array}$ & $\begin{array}{c}1.02 * * * \\
(0.11)\end{array}$ \\
\hline Ireland & $\begin{array}{c}0.64 * * * \\
(0.01)\end{array}$ & $\begin{array}{c}0.83 * * * \\
(0.01) \\
\end{array}$ & & $\begin{array}{c}0.90 * * * \\
(0.05)\end{array}$ & $\begin{array}{c}0.09 \\
(0.06) \\
\end{array}$ & $\begin{array}{c}0.001 * * * \\
(0.0004)\end{array}$ & \\
\hline Portugal & $\begin{array}{c}2.17 * * * \\
(0.02)\end{array}$ & $\begin{array}{c}5.74 * * * \\
(0.10)\end{array}$ & $\begin{array}{c}2.14 * * * \\
(0.04)\end{array}$ & $\begin{array}{c}0.65 * * * \\
(0.12)\end{array}$ & $\begin{array}{c}0.34 * * \\
(0.14)\end{array}$ & $\begin{array}{c}0.004 \\
(0.003)\end{array}$ & \\
\hline Spain & $\begin{array}{c}1.35 * * * \\
(0.01)\end{array}$ & $\begin{array}{c}1.16^{* * *} \\
(0.02)\end{array}$ & $\begin{array}{c}0.78 * * * \\
(0.02)\end{array}$ & $\begin{array}{c}0.02 \\
(0.02) \\
\end{array}$ & $\begin{array}{c}0.95 * * * \\
(0.01)\end{array}$ & $\begin{array}{c}-0.20 * * * \\
(0.03)\end{array}$ & $\begin{array}{c}1.03 * * * \\
(0.10)\end{array}$ \\
\hline Italy & $\begin{array}{c}1.36 * * * \\
(0.01) \\
\end{array}$ & $\begin{array}{c}2.76 * * * \\
(0.06)\end{array}$ & $\begin{array}{c}0.19 * * * \\
(0.01) \\
\end{array}$ & $\begin{array}{l}0.04^{*} \\
(0.02) \\
\end{array}$ & $\begin{array}{c}0.94 * * * \\
(0.02) \\
\end{array}$ & $\begin{array}{c}-0.26^{* * *} \\
(0.05) \\
\end{array}$ & $\begin{array}{c}1.27 * * * \\
(0.14) \\
\end{array}$ \\
\hline France & $\begin{array}{c}0.34 * * * \\
(0.003)\end{array}$ & $\begin{array}{c}0.42 * * * \\
(0.01)\end{array}$ & $\begin{array}{c}0.02 * * * \\
(0.01)\end{array}$ & $\begin{array}{c}0.01 \\
(0.02) \\
\end{array}$ & $\begin{array}{c}0.94 * * * \\
(0.01)\end{array}$ & $\begin{array}{c}-0.36 * * * \\
(0.08)\end{array}$ & $\begin{array}{c}0.92 * * * \\
(0.10)\end{array}$ \\
\hline Netherlands & $\begin{array}{c}0.22 * * * \\
(0.002)\end{array}$ & $\begin{array}{c}0.06 * * * \\
(0.004)\end{array}$ & $\begin{array}{c}0.07 * * * \\
(0.01)\end{array}$ & $\begin{array}{c}0.02 \\
(0.02) \\
\end{array}$ & $\begin{array}{c}0.88 * * * \\
(0.02)\end{array}$ & $\begin{array}{c}-0.80 * * * \\
(0.10)\end{array}$ & $\begin{array}{c}1.20 * * * \\
(0.09)\end{array}$ \\
\hline Belgium & $\begin{array}{c}2.42 * * * \\
(0.01)\end{array}$ & $\begin{array}{c}1.23 * * * \\
(0.01) \\
\end{array}$ & $\begin{array}{c}1.80 * * * \\
(0.02)\end{array}$ & $\begin{array}{c}-0.03 * * \\
(0.01)\end{array}$ & $\begin{array}{c}0.97 * * * \\
(0.01)\end{array}$ & $\begin{array}{c}-0.12 * * * \\
(0.02) \\
\end{array}$ & $\begin{array}{c}0.64 * * * \\
(0.06)\end{array}$ \\
\hline Poland & $\begin{array}{c}2.26 * * * \\
(0.01)\end{array}$ & $\begin{array}{c}0.81 * * * \\
(0.02)\end{array}$ & $\begin{array}{c}0.83 * * * \\
(0.01)\end{array}$ & $\begin{array}{c}0.06 * * \\
(0.02)\end{array}$ & $\begin{array}{c}0.85 * * * \\
(0.02)\end{array}$ & $\begin{array}{c}-0.55^{* * *} \\
(0.07)\end{array}$ & $\begin{array}{c}1.33 * * * \\
(0.11)\end{array}$ \\
\hline $\begin{array}{l}\text { Czech } \\
\text { Republic }\end{array}$ & $\begin{array}{c}0.34 * * * \\
(0.01)\end{array}$ & $\begin{array}{c}0.67 * * * \\
(0.02)\end{array}$ & $\begin{array}{c}0.44 * * * \\
(0.01)\end{array}$ & $\begin{array}{c}0.02 \\
(0.02) \\
\end{array}$ & $\begin{array}{c}0.90 * * * \\
(0.02)\end{array}$ & $\begin{array}{c}-0.45^{* * *} \\
(0.06)\end{array}$ & $\begin{array}{c}1.09 * * * \\
(0.08)\end{array}$ \\
\hline Hungary & $\begin{array}{c}3.20 * * * \\
(0.02)\end{array}$ & $\begin{array}{c}1.40 * * * \\
(0.04)\end{array}$ & $\begin{array}{c}1.18 * * * \\
(0.03)\end{array}$ & $\begin{array}{c}0.93 * * * \\
(0.06)\end{array}$ & $\begin{array}{c}0.06 \\
(0.06) \\
\end{array}$ & $\begin{array}{c}0.01 * * * \\
(0.002)\end{array}$ & \\
\hline Switzerland & $\begin{array}{c}-0.63 * * * \\
(0.002)\end{array}$ & $\begin{array}{c}-0.51 * * * \\
(0.01)\end{array}$ & $\begin{array}{c}-0.57 * * * \\
(0.003)\end{array}$ & $\begin{array}{c}0.01 \\
(0.01) \\
\end{array}$ & $\begin{array}{c}0.94 * * * \\
(0.01)\end{array}$ & $\begin{array}{c}-0.27 * * * \\
(0.04)\end{array}$ & $\begin{array}{c}0.80 * * * \\
(0.07)\end{array}$ \\
\hline U.K. & $\begin{array}{c}1.18 * * * \\
(0.01)\end{array}$ & $\begin{array}{c}-0.29 * * * \\
(0.003)\end{array}$ & $\begin{array}{c}-0.70 * * * \\
(0.005)\end{array}$ & $\begin{array}{l}-0.01 \\
(0.02) \\
\end{array}$ & $\begin{array}{c}0.95 * * * \\
(0.01)\end{array}$ & $\begin{array}{c}-0.26^{* * *} \\
(0.06)\end{array}$ & $\begin{array}{c}0.82 * * * \\
(0.11)\end{array}$ \\
\hline Sweden & $\begin{array}{c}0.37 * * * \\
(0.003)\end{array}$ & $\begin{array}{c}-0.34 * * * \\
(0.002)\end{array}$ & $\begin{array}{c}-0.20 * * * \\
(0.004)\end{array}$ & $\begin{array}{l}-0.01 \\
(0.02) \\
\end{array}$ & $\begin{array}{c}0.89 * * * \\
(0.02)\end{array}$ & $\begin{array}{c}-0.56^{* * *} \\
(0.08)\end{array}$ & $\begin{array}{c}1.12 * * * \\
(0.11)\end{array}$ \\
\hline
\end{tabular}

Note: $* * *, * *$ and $*$ indicate the significant levels of $1 \%, 5 \%$ and $10 \%$ respectively.

Diagnostics: $\mathrm{LL}=19505.46, !_{1}=0.34$ (0.02), !! ${ }_{2}=0.64$ (0.02) and $! !_{3}=0.005$ (0.001), AIC $=-22.11, \mathrm{BIC}=-21.47, \mathrm{H}-$ $\mathrm{Q}=-21.87$

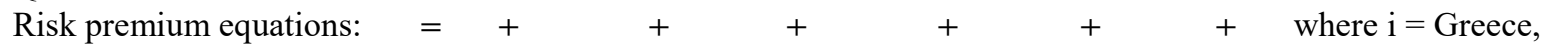
Ireland, Portugal, Spain, Italy, France, Netherlands, Belgium, Switzerland, U.K., Sweden, Poland, Czech Republic

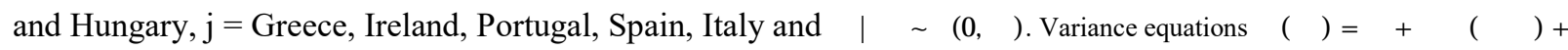

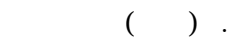


Table 8B. Estimation Results from the Quantile Model for Greece and Ireland (with Static Exchange Rate Expectations)

\begin{tabular}{|c|c|c|c|c|c|c|}
\hline & & & & \multicolumn{3}{|c|}{ Diagnostics } \\
\hline & $C_{\text {:F }}$ & $C_{860^{\circ}}$ & $\mathrm{C}_{36^{\circ}}$ & $\begin{array}{c}0.25 \\
\text { Pseudo } \\
\text { R-square }\end{array}$ & $\begin{array}{c}0.50 \\
\text { Pseudo } \\
\text { R-square }\end{array}$ & $\begin{array}{c}0.75 \\
\text { Pseudo } \\
\text { R-square }\end{array}$ \\
\hline Greece & $\begin{array}{c}10.00 * * * \\
(0.18)\end{array}$ & & $\begin{array}{c}15.35 * * * \\
(0.98) \\
\end{array}$ & & & 0.22 \\
\hline Ireland & $\begin{array}{c}3.13 * * * \\
(0.13)\end{array}$ & $\begin{array}{c}2.88 * * * \\
(0.12)\end{array}$ & & & & 0.13 \\
\hline Portugal & $\begin{array}{c}4.28 * * * \\
(0.07)\end{array}$ & $\begin{array}{c}4.34 * * * \\
(0.27)\end{array}$ & $\begin{array}{c}2.86 * * * \\
(0.32)\end{array}$ & & & 0.42 \\
\hline Spain & $\begin{array}{c}1.48 * * * \\
(0.03)\end{array}$ & $\begin{array}{c}1.22 * * * \\
(0.12)\end{array}$ & $\begin{array}{c}0.86 * * * \\
(0.06)\end{array}$ & & 0.18 & \\
\hline Italy & $\begin{array}{c}2.35 * * * \\
(0.04)\end{array}$ & $\begin{array}{c}1.93 * * * \\
(0.10)\end{array}$ & $\begin{array}{c}0.35 * * * \\
(0.10)\end{array}$ & & & 0.28 \\
\hline France & $\begin{array}{c}0.54 * * * \\
(0.01)\end{array}$ & $\begin{array}{c}0.56 * * * \\
(0.02)\end{array}$ & $\begin{array}{c}0.13 * * * \\
(0.01)\end{array}$ & & & 0.33 \\
\hline Netherlands & $\begin{array}{c}0.21 * * * \\
(0.003)\end{array}$ & $\begin{array}{c}0.11 * * * \\
(0.01)\end{array}$ & $\begin{array}{c}0.08 * * * \\
(0.01)\end{array}$ & & 0.17 & \\
\hline Belgium & $\begin{array}{c}2.54 * * * \\
(0.03)\end{array}$ & $\begin{array}{c}1.11 * * * \\
(0.03)\end{array}$ & $\begin{array}{c}1.68 * * * \\
(0.03) \\
\end{array}$ & & & 0.35 \\
\hline Poland & $\begin{array}{c}2.81 * * * \\
(0.01)\end{array}$ & $\begin{array}{c}0.77 * * * \\
(0.02)\end{array}$ & $\begin{array}{c}0.43 * * * \\
(0.02)\end{array}$ & & & 0.36 \\
\hline $\begin{array}{l}\text { Czech } \\
\text { Republic }\end{array}$ & $\begin{array}{c}0.40 * * * \\
(0.01)\end{array}$ & $\begin{array}{c}0.66 * * * \\
(0.04)\end{array}$ & $\begin{array}{c}0.50 * * * \\
(0.02)\end{array}$ & & 0.36 & \\
\hline Hungary & $\begin{array}{c}4.55 * * * \\
(0.03)\end{array}$ & $\begin{array}{c}1.99 * * * \\
(0.08)\end{array}$ & $\begin{array}{c}0.60 * * * \\
(0.07)\end{array}$ & & & 0.34 \\
\hline Switzerland & $\begin{array}{c}-0.88 * * * \\
(0.01)\end{array}$ & $\begin{array}{c}-0.31 * * * \\
(0.02)\end{array}$ & $\begin{array}{c}-0.35 * * * \\
(0.02)\end{array}$ & 0.21 & & \\
\hline U.K. & $\begin{array}{l}1.26 * * * \\
(0.005)\end{array}$ & $\begin{array}{c}-0.35 * * * \\
(0.02)\end{array}$ & $\begin{array}{c}-0.56^{* * *} \\
(0.01) \\
\end{array}$ & & & 0.31 \\
\hline Sweden & $\begin{array}{c}0.52 * * * \\
(0.01)\end{array}$ & $\begin{array}{c}-0.41 * * * \\
(0.01)\end{array}$ & $\begin{array}{c}-0.21 * * * \\
(0.02)\end{array}$ & & & 0.31 \\
\hline
\end{tabular}

Note: $* * *$ indicates the significant level of $1 \%$.

Number of observations $=1746$

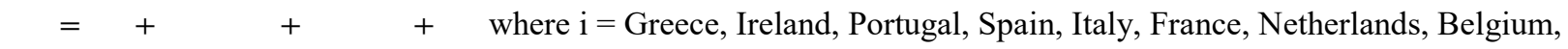
Switzerland, U.K., Sweden, Poland, Czech Republic and Hungary 
Table 9A. Results from the aDCC- M-eGARCH model for Greece and Ireland (with Static Exchange Rate Expectations and weekly data).

\begin{tabular}{|c|c|c|c|c|c|c|c|}
\hline & \multicolumn{3}{|c|}{ Mean relation } & \multicolumn{4}{|c|}{ Variance model } \\
\hline & $C_{\text {偪 }}$ & $\mathrm{C}_{56^{\circ}}$ & $\mathrm{C}_{30^{\circ}}$ & ઈા & Q & ๑ & $\gamma$ \\
\hline Greece & $\begin{array}{c}7.90 * * * \\
(0.40)\end{array}$ & & $\begin{array}{c}1.24 * * * \\
(0.43)\end{array}$ & $\begin{array}{c}0.81^{* * *} \\
(0.12)\end{array}$ & $\begin{array}{c}0.18^{* *} \\
(0.09)\end{array}$ & $\begin{array}{c}0.11^{* * *} \\
(0.04)\end{array}$ & \\
\hline Ireland & $\begin{array}{c}0.80 * * * \\
(0.01)\end{array}$ & $\begin{array}{c}0.52 * * * \\
(0.02)\end{array}$ & & $\begin{array}{c}-0.23 * \\
(0.13)\end{array}$ & $\begin{array}{c}0.94 * * * \\
(0.03)\end{array}$ & $\begin{array}{l}-0.04 \\
(0.11)\end{array}$ & $\begin{array}{c}1.98 * * * \\
(0.26)\end{array}$ \\
\hline Portugal & $\begin{array}{c}2.17 * * * \\
(0.05)\end{array}$ & $\begin{array}{c}-1.45 * * * \\
(0.07)\end{array}$ & $\begin{array}{c}1.72 * * * \\
(0.08)\end{array}$ & $\begin{array}{c}0.99 * * * \\
(0.06)\end{array}$ & $\begin{array}{c}0.00 \\
(0.003)\end{array}$ & $\begin{array}{c}0.03 * * \\
(0.01)\end{array}$ & \\
\hline Spain & $\begin{array}{c}1.36^{* * * *} \\
(0.03)\end{array}$ & $\begin{array}{c}1.23 * * * \\
(0.06)\end{array}$ & $\begin{array}{c}0.81 * * * \\
(0.04)\end{array}$ & $\begin{array}{c}0.05 \\
(0.05)\end{array}$ & $\begin{array}{c}0.88 * * * \\
(0.03)\end{array}$ & $\begin{array}{c}-0.28 * * * \\
(0.07)\end{array}$ & $\begin{array}{c}1.37 * * * \\
(0.18)\end{array}$ \\
\hline Italy & $\begin{array}{l}1.36^{* * * *} \\
(0.002) \\
\end{array}$ & $\begin{array}{c}-0.54 * * * \\
(0.002) \\
\end{array}$ & $\begin{array}{c}0.32 * * * \\
(0.01) \\
\end{array}$ & $\begin{array}{c}0.10 \\
(0.15) \\
\end{array}$ & $\begin{array}{c}0.81^{* * *} \\
(0.07) \\
\end{array}$ & $\begin{array}{c}-0.48^{* * * *} \\
(0.15) \\
\end{array}$ & $\begin{array}{c}2.23 * * * \\
(0.12) \\
\end{array}$ \\
\hline France & $\begin{array}{c}0.35^{* * *} \\
(0.01)\end{array}$ & $\begin{array}{c}-0.06^{* * *} * \\
(0.01)\end{array}$ & $\begin{array}{l}0.02 * * \\
(0.01)\end{array}$ & $\begin{array}{l}0.16^{*} \\
(0.09)\end{array}$ & $\begin{array}{c}0.83^{* * *} \\
(0.05)\end{array}$ & $\begin{array}{c}-0.90 * * * \\
(0.22)\end{array}$ & $\begin{array}{c}1.40^{* * * *} \\
(0.14)\end{array}$ \\
\hline Netherlands & $\begin{array}{c}0.20^{* * *} \\
(0.001) \\
\end{array}$ & $\begin{array}{c}0.09 * * * \\
(0.004) \\
\end{array}$ & $\begin{array}{c}0.08^{* * * *} \\
(0.001) \\
\end{array}$ & $\begin{array}{c}0.10 \\
(0.11) \\
\end{array}$ & $\begin{array}{c}0.66^{* * *} \\
(0.04) \\
\end{array}$ & $\begin{array}{c}-2.02 * * * \\
(0.22) \\
\end{array}$ & $\begin{array}{c}2.18^{* * * *} \\
(0.26)\end{array}$ \\
\hline Belgium & $\begin{array}{c}2.40^{* * *} \\
(0.01) \\
\end{array}$ & $\begin{array}{c}1.27 * * * \\
(0.02)\end{array}$ & $\begin{array}{c}1.78^{* * *} \\
(0.03) \\
\end{array}$ & $\begin{array}{c}-0.22 * * * \\
(0.07)\end{array}$ & $\begin{array}{c}0.91 * * * \\
(0.03)\end{array}$ & $\begin{array}{c}-0.25 * * * \\
(0.08)\end{array}$ & $\begin{array}{c}1.38 * * * \\
(0.25) \\
\end{array}$ \\
\hline Poland & $\begin{array}{c}2.42 * * * \\
(0.05)\end{array}$ & $\begin{array}{c}0.73 * * * \\
(0.10)\end{array}$ & $\begin{array}{c}0.73 * * * \\
(0.16)\end{array}$ & $\begin{array}{c}0.03 \\
(0.04) \\
\end{array}$ & $\begin{array}{c}0.75^{* * *} * \\
(0.06)\end{array}$ & $\begin{array}{c}-0.70 * * * \\
(0.15)\end{array}$ & $\begin{array}{c}1.12 * * * \\
(0.14)\end{array}$ \\
\hline $\begin{array}{l}\text { Czech } \\
\text { Republic }\end{array}$ & $\begin{array}{c}0.30^{* * * *} \\
(0.02)\end{array}$ & $\begin{array}{c}0.71 * * * \\
(0.02)\end{array}$ & $\begin{array}{c}0.45^{* * *} \\
(0.04)\end{array}$ & $\begin{array}{c}0.08 \\
(0.08)\end{array}$ & $\begin{array}{c}0.75^{* * *} \\
(0.07)\end{array}$ & $\begin{array}{c}-0.89 * * * \\
(0.25)\end{array}$ & $\begin{array}{c}1.64 * * * \\
(0.32)\end{array}$ \\
\hline Hungary & $\begin{array}{c}3.24 * * * \\
(0.03) \\
\end{array}$ & $\begin{array}{c}1.18^{* * *} \\
(0.04) \\
\end{array}$ & $\begin{array}{c}1.10^{* * *} \\
(0.05) \\
\end{array}$ & $\begin{array}{c}0.21^{* * *} \\
(0.11) \\
\end{array}$ & $\begin{array}{c}0.72 * * * \\
(0.04) \\
\end{array}$ & $\begin{array}{c}-0.51 * * * \\
(0.11)\end{array}$ & $\begin{array}{c}2.00 * * * \\
(0.24)\end{array}$ \\
\hline Switzerland & $\begin{array}{c}-0.74 * * * \\
(0.01)\end{array}$ & $\begin{array}{c}-0.13 * * * \\
(0.01) \\
\end{array}$ & $\begin{array}{c}-0.44 * * * \\
(0.01) \\
\end{array}$ & $\begin{array}{c}0.02 \\
(0.04) \\
\end{array}$ & $\begin{array}{c}0.86^{* * * *} \\
(0.03)\end{array}$ & $\begin{array}{c}-0.67 * * * \\
(0.11)\end{array}$ & $\begin{array}{c}1.60^{* * * *} \\
(0.11)\end{array}$ \\
\hline U.K. & $\begin{array}{c}1.13^{* * *} \\
(0.01) \\
\end{array}$ & $\begin{array}{c}-0.46^{* * *} * \\
(0.02) \\
\end{array}$ & $\begin{array}{c}-0.59 * * * \\
(0.01) \\
\end{array}$ & $\begin{array}{c}0.01 \\
(0.04) \\
\end{array}$ & $\begin{array}{c}0.90^{* * *} \\
(0.04) \\
\end{array}$ & $\begin{array}{c}-0.42 * * * \\
(0.13) \\
\end{array}$ & $\begin{array}{c}1.18^{* * * *} \\
(0.13)\end{array}$ \\
\hline Sweden & $\begin{array}{c}0.45^{* * *} \\
(0.02) \\
\end{array}$ & $\begin{array}{c}-0.43 * * * \\
(0.02) \\
\end{array}$ & $\begin{array}{c}-0.25 * * * \\
(0.05) \\
\end{array}$ & $\begin{array}{l}-0.05 \\
(0.05) \\
\end{array}$ & $\begin{array}{c}0.82^{* * *} \\
(0.05) \\
\end{array}$ & $\begin{array}{c}-0.82 * * * \\
(0.16) \\
\end{array}$ & $\begin{array}{c}1.33^{* * * *} \\
(0.14) \\
\end{array}$ \\
\hline Japan & $\begin{array}{c}-0.62 * * * \\
(0.03)\end{array}$ & $\begin{array}{c}0.05 \\
(0.09)\end{array}$ & $\begin{array}{c}-0.37 * * * \\
(0.10)\end{array}$ & $\begin{array}{l}-0.04 \\
(0.09)\end{array}$ & $\begin{array}{c}0.69 * * * \\
(0.08)\end{array}$ & $\begin{array}{c}-0.96 * * * \\
(0.10)\end{array}$ & $\begin{array}{c}2.43 * * \\
(1.09)\end{array}$ \\
\hline U.S. & $\begin{array}{c}1.02 * * * \\
(0.01)\end{array}$ & $\begin{array}{c}-0.35 * * * \\
(0.004)\end{array}$ & $\begin{array}{c}-0.60 * * * \\
(0.001)\end{array}$ & $\begin{array}{c}0.02 \\
(0.42)\end{array}$ & $\begin{array}{c}0.87 * * * \\
(0.11)\end{array}$ & $\begin{array}{c}-0.64 * * \\
(0.26)\end{array}$ & $\begin{array}{c}2.71^{* * * *} \\
(0.29)\end{array}$ \\
\hline
\end{tabular}

Note: Results from the aDCC-M-eGARCH-TGARCH and the aDCC-M-eGARCH-NAGARCH models are the same as these.

Note: $* * *, * *$ and $*$ indicate the significant levels of $1 \%, 5 \%$ and $10 \%$ respectively.

Diagnostics: $\mathrm{LL}=2309.71, !_{1}=0.57(0.06), !_{2}=0.28(0.08)$ and $! !_{3}=0.01(0.005), \mathrm{AIC}=-11.47, \mathrm{BIC}=-8.77, \mathrm{H}-\mathrm{Q}=-$ 10.40

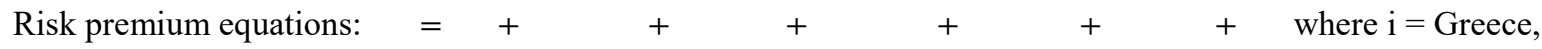
Ireland, Portugal, Spain, Italy, France, Netherlands, Belgium, Switzerland, U.K., Sweden, Poland, Czech Republic

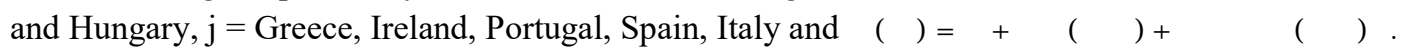


Table 9B. Results from the Quantile Model for Greece and Ireland (with Static Exchange Rate Expectations and weekly data)

\begin{tabular}{|c|c|c|c|c|c|c|}
\hline & & & & \multicolumn{3}{|c|}{ Diagnostics } \\
\hline & $C_{\text {:F }}$ & $C_{86^{\circ}}$ & $\mathrm{C}_{20^{\circ}}$ & $\begin{array}{c}0.25 \\
\text { Pseudo } \\
\text { R-square }\end{array}$ & $\begin{array}{c}0.50 \\
\text { Pseudo } \\
\text { R-square }\end{array}$ & $\begin{array}{c}0.75 \\
\text { Pseudo } \\
\text { R-square }\end{array}$ \\
\hline Greece & $\begin{array}{c}10.01 * * * \\
(0.29)\end{array}$ & & $\begin{array}{c}16.94 * * * \\
(1.90)\end{array}$ & & & 0.23 \\
\hline Ireland & $\begin{array}{c}3.06 * * * \\
(0.27)\end{array}$ & $\begin{array}{c}2.97 * * * \\
(0.34)\end{array}$ & & & & 0.13 \\
\hline Portugal & $\begin{array}{c}4.29 * * * \\
(0.19)\end{array}$ & $\begin{array}{c}4.33 * * * \\
(0.60)\end{array}$ & $\begin{array}{c}3.02 * * * \\
(0.57)\end{array}$ & & & 0.42 \\
\hline Spain & $\begin{array}{c}1.48 * * * \\
(0.05)\end{array}$ & $\begin{array}{c}1.11 * * * \\
(0.28)\end{array}$ & $\begin{array}{c}0.98 * * * \\
(0.12)\end{array}$ & & 0.19 & \\
\hline Italy & $\begin{array}{c}2.36 * * * \\
(0.12)\end{array}$ & $\begin{array}{c}1.89 * * * \\
(0.22)\end{array}$ & $\begin{array}{c}0.40 \\
(0.26) \\
\end{array}$ & & & 0.28 \\
\hline France & $\begin{array}{c}0.54 * * * \\
(0.02)\end{array}$ & $\begin{array}{c}0.55 * * * \\
(0.05)\end{array}$ & $\begin{array}{c}0.12 * * * \\
(0.04)\end{array}$ & & & 0.34 \\
\hline Netherlands & $\begin{array}{c}0.21 * * * \\
(0.01)\end{array}$ & $\begin{array}{c}0.12 * * * \\
(0.02)\end{array}$ & $\begin{array}{c}0.08 * * * \\
(0.01)\end{array}$ & & 0.17 & \\
\hline Belgium & $\begin{array}{c}2.53 * * * \\
(0.07)\end{array}$ & $\begin{array}{c}1.13 * * * \\
(0.08) \\
\end{array}$ & $\begin{array}{c}1.68 * * * \\
(0.09)\end{array}$ & & & 0.37 \\
\hline Poland & $\begin{array}{c}2.19 * * * \\
(0.02)\end{array}$ & $\begin{array}{c}0.71 * * * \\
(0.04)\end{array}$ & $\begin{array}{c}0.81 * * * \\
(0.04)\end{array}$ & 0.38 & & \\
\hline $\begin{array}{l}\text { Czech } \\
\text { Republic }\end{array}$ & $\begin{array}{c}0.40 * * * \\
(0.03)\end{array}$ & $\begin{array}{c}0.71 * * * \\
(0.06)\end{array}$ & $\begin{array}{c}0.51 * * * \\
(0.05)\end{array}$ & & 0.37 & \\
\hline Hungary & $\begin{array}{c}4.53 * * * \\
(0.10)\end{array}$ & $\begin{array}{c}2.07 * * * \\
(0.13)\end{array}$ & $\begin{array}{c}0.58 * * * \\
(0.15)\end{array}$ & & & 0.35 \\
\hline Switzerland & $\begin{array}{c}-0.86^{* * *} \\
(0.02)\end{array}$ & $\begin{array}{c}-0.33 * * * \\
(0.03)\end{array}$ & $\begin{array}{c}-0.36^{* * *} \\
(0.04)\end{array}$ & 0.22 & & \\
\hline U.K. & $\begin{array}{c}1.26 * * * \\
(0.01)\end{array}$ & $\begin{array}{c}-0.36 * * * \\
(0.06)\end{array}$ & $\begin{array}{c}-0.59 * * * \\
(0.04)\end{array}$ & & & 0.32 \\
\hline Sweden & $\begin{array}{c}0.52 * * * \\
(0.01)\end{array}$ & $\begin{array}{c}-0.40 * * * \\
(0.03)\end{array}$ & $\begin{array}{c}-0.23 * * * \\
(0.03)\end{array}$ & & & 0.32 \\
\hline Japan & $\begin{array}{c}-1.11 * * * \\
(0.07)\end{array}$ & $\begin{array}{c}-0.73 * * * \\
(0.22)\end{array}$ & $\begin{array}{c}-0.79 * * * \\
(0.09)\end{array}$ & 0.18 & & \\
\hline U.S. & $\begin{array}{c}1.53 * * * \\
(0.02)\end{array}$ & $\begin{array}{c}-0.98 * * * \\
(0.23)\end{array}$ & $\begin{array}{l}-0.46^{*} \\
(0.25) \\
\end{array}$ & & & 0.33 \\
\hline
\end{tabular}

Note: $* * *$ and $*$ indicate the significant levels of $1 \%$ and $10 \%$ respectively.

Number of observations $=359$

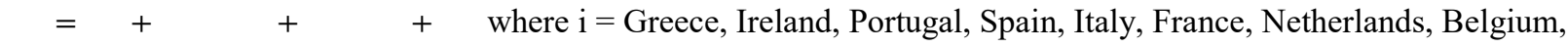
Switzerland, U.K., Sweden, Japan, U.S., Poland, Czech Republic and Hungary. 
Table 10A. Results from the Quantile Model in the First Greek Crisis (with Static Exchange Rate Expectations and weekly data)

\begin{tabular}{|c|c|c|c|c|c|c|}
\hline & & & & \multicolumn{3}{|c|}{ Diagnostics } \\
\hline & $C_{i z}$ & $C_{866^{\circ}}$ & $\mathrm{C}_{36^{\circ}}$ & $\begin{array}{c}0.25 \\
\text { Pseudo } \\
\text { R-square }\end{array}$ & $\begin{array}{c}0.50 \\
\text { Pseudo } \\
\text { R-square }\end{array}$ & $\begin{array}{c}0.75 \\
\text { Pseudo } \\
\text { R-square }\end{array}$ \\
\hline Greece & $\begin{array}{c}9.66^{* * * *} \\
(0.40)\end{array}$ & & $\begin{array}{c}17.28 * * * \\
(2.21)\end{array}$ & & & 0.21 \\
\hline Ireland & $\begin{array}{c}2.55 * * * \\
(0.18)\end{array}$ & $\begin{array}{c}2.46 * * * \\
(0.21)\end{array}$ & & & 0.10 & \\
\hline Portugal & $\begin{array}{c}4.84 * * * \\
(0.10) \\
\end{array}$ & $\begin{array}{c}3.85 * * * \\
(0.65) \\
\end{array}$ & $\begin{array}{c}2.94 * * * \\
(0.68) \\
\end{array}$ & & & 0.41 \\
\hline Spain & $\begin{array}{c}1.52 * * * \\
(0.05)\end{array}$ & $\begin{array}{c}-0.79 * * \\
(0.36)\end{array}$ & $\begin{array}{c}0.73 * * * \\
(0.11)\end{array}$ & 0.15 & & \\
\hline Italy & $\begin{array}{c}2.65 * * * \\
(0.08)\end{array}$ & $\begin{array}{c}1.73 * * * \\
(0.16)\end{array}$ & $\begin{array}{c}0.21 \\
(0.16)\end{array}$ & & & 0.28 \\
\hline France & $\begin{array}{c}0.59 * * * \\
(0.01)\end{array}$ & $\begin{array}{c}0.54 * * * \\
(0.06)\end{array}$ & $\begin{array}{c}0.08 \\
(0.06)\end{array}$ & & & 0.37 \\
\hline Netherlands & $\begin{array}{c}0.33 * * * \\
(0.01)\end{array}$ & $\begin{array}{c}0.10 * * * \\
(0.03)\end{array}$ & $\begin{array}{l}0.04 * \\
(0.02)\end{array}$ & & & 0.13 \\
\hline Belgium & $\begin{array}{c}2.49 * * * \\
(0.04)\end{array}$ & $\begin{array}{c}0.42 \\
(0.27)\end{array}$ & $\begin{array}{c}1.55^{* * *} \\
(0.08)\end{array}$ & & 0.42 & \\
\hline Poland & $\begin{array}{c}2.31 * * * \\
(0.05)\end{array}$ & $\begin{array}{c}0.63 * * * \\
(0.05)\end{array}$ & $\begin{array}{c}0.73 * * * \\
(0.05)\end{array}$ & 0.39 & & \\
\hline $\begin{array}{l}\text { Czech } \\
\text { Republic }\end{array}$ & $\begin{array}{c}0.57 * * * \\
(0.02)\end{array}$ & $\begin{array}{c}0.61 * * * \\
(0.09)\end{array}$ & $\begin{array}{c}0.42 * * * \\
(0.06)\end{array}$ & & 0.34 & \\
\hline Hungary & $\begin{array}{c}4.79 * * * \\
(0.05)\end{array}$ & $\begin{array}{c}1.92 * * * \\
(0.10)\end{array}$ & $\begin{array}{c}0.44 * * * \\
(0.11)\end{array}$ & & & 0.41 \\
\hline Switzerland & $\begin{array}{c}-0.65 * * * \\
(0.02)\end{array}$ & $\begin{array}{l}-0.11 \\
(0.07)\end{array}$ & $\begin{array}{c}-0.28 * * \\
(0.12)\end{array}$ & & & 0.17 \\
\hline U.K. & $\begin{array}{c}1.06 * * * \\
(0.02)\end{array}$ & $\begin{array}{c}-0.22 * * * \\
(0.06)\end{array}$ & $\begin{array}{c}-0.48 * * * \\
(0.05)\end{array}$ & & & 0.27 \\
\hline Sweden & $\begin{array}{c}0.52 * * * \\
(0.01)\end{array}$ & $\begin{array}{c}-0.40 * * * \\
(0.02)\end{array}$ & $\begin{array}{c}-0.23 * * * \\
(0.04)\end{array}$ & & & 0.42 \\
\hline Japan & $\begin{array}{c}-1.34 * * * \\
(0.08)\end{array}$ & $\begin{array}{l}-0.50 \\
(0.33)\end{array}$ & $\begin{array}{c}-0.55 * * * \\
(0.09)\end{array}$ & 0.14 & & \\
\hline U.S. & $\begin{array}{c}0.99 * * * \\
(0.04)\end{array}$ & $\begin{array}{c}-0.33 * * * \\
(0.09)\end{array}$ & $\begin{array}{c}-0.60 * * * \\
(0.07)\end{array}$ & & & 0.33 \\
\hline
\end{tabular}

Note: $* * *, * *$ and $*$ indicate the significant levels of $1 \%, 5 \%$ and $10 \%$ respectively.

Number of observations $=260$

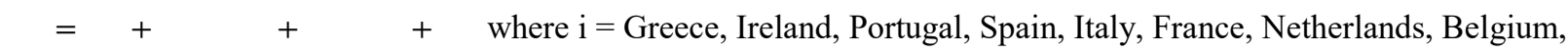
Switzerland, U.K., Sweden, Poland, Czech Republic and Hungary 
Table 10B. Results from the Quantile Model in the Second Greek Crisis (with Static Exchange Rate Expectations and weekly data)

\begin{tabular}{|c|c|c|c|c|c|c|}
\hline & & & & \multicolumn{3}{|c|}{ Diagnostics } \\
\hline & $C_{i_{B}}$ & $\mathrm{C}_{686^{\circ}}$ & $\mathrm{C}_{36^{\circ}}$ & $\begin{array}{c}0.25 \\
\text { Pseudo } \\
\text { R-square }\end{array}$ & $\begin{array}{c}0.50 \\
\text { Pseudo } \\
\text { R-square }\end{array}$ & $\begin{array}{c}0.75 \\
\text { Pseudo } \\
\text { R-square }\end{array}$ \\
\hline Greece & $\begin{array}{c}10.10 * * * \\
(0.31)\end{array}$ & & $\begin{array}{l}-1.76 \\
(2.35)\end{array}$ & & & 0.01 \\
\hline Ireland & $\begin{array}{c}0.72 * * * \\
(0.02)\end{array}$ & $\begin{array}{c}0.39 * * * \\
(0.04)\end{array}$ & & & & 0.03 \\
\hline Portugal & $\begin{array}{c}1.88^{* * *} \\
(0.03) \\
\end{array}$ & $\begin{array}{c}1.00^{* * *} \\
(0.08) \\
\end{array}$ & $\begin{array}{c}0.76 \\
(0.92) \\
\end{array}$ & 0.02 & & \\
\hline Spain & $\begin{array}{c}1.36 * * * \\
(0.02)\end{array}$ & $\begin{array}{c}0.35^{* * *} \\
(0.04)\end{array}$ & $\begin{array}{l}-0.26 \\
(0.18)\end{array}$ & & & 0.06 \\
\hline Italy & $\begin{array}{c}1.34 * * * \\
(0.01)\end{array}$ & $\begin{array}{c}0.38 * * * \\
(0.04)\end{array}$ & $\begin{array}{l}-0.17 \\
(0.38)\end{array}$ & & & 0.04 \\
\hline France & $\begin{array}{c}0.35 * * * \\
(0.004)\end{array}$ & $\begin{array}{c}0.23 * * * \\
(0.01)\end{array}$ & $\begin{array}{l}-0.07 \\
(0.10)\end{array}$ & & & 0.05 \\
\hline Netherlands & $\begin{array}{c}0.19 * * * \\
(0.01)\end{array}$ & $\begin{array}{c}0.28 * * * \\
(0.03)\end{array}$ & $\begin{array}{c}-0.10^{* *} \\
(0.04)\end{array}$ & & & 0.07 \\
\hline Belgium & $\begin{array}{c}0.99 * * * \\
(0.04) \\
\end{array}$ & $\begin{array}{c}0.62^{* * *} \\
(0.09) \\
\end{array}$ & $\begin{array}{c}-0.48 * * * \\
(0.13) \\
\end{array}$ & & & 0.05 \\
\hline Poland & $\begin{array}{c}2.23 * * * \\
(0.03)\end{array}$ & $\begin{array}{c}0.31 * * * \\
(0.07)\end{array}$ & $\begin{array}{c}0.91 * * * \\
(0.21)\end{array}$ & & 0.04 & \\
\hline $\begin{array}{l}\text { Czech } \\
\text { Republic }\end{array}$ & $\begin{array}{c}0.11 * * * \\
(0.02)\end{array}$ & $\begin{array}{c}0.92^{* * *} \\
(0.06)\end{array}$ & $\begin{array}{c}0.25^{* * *} \\
(0.05)\end{array}$ & 0.04 & & \\
\hline Hungary & $\begin{array}{c}2.91 * * * \\
(0.02) \\
\end{array}$ & $\begin{array}{c}0.69^{* * * *} \\
(0.05) \\
\end{array}$ & $\begin{array}{c}0.08 \\
(0.34) \\
\end{array}$ & 0.01 & & \\
\hline Switzerland & $\begin{array}{c}-0.51 * * * \\
(0.03)\end{array}$ & $\begin{array}{c}-0.49 * * * \\
(0.07) \\
\end{array}$ & $\begin{array}{l}-0.23 \\
(0.20) \\
\end{array}$ & & 0.02 & \\
\hline U.K. & $\begin{array}{c}1.22 * * * \\
(0.02)\end{array}$ & $\begin{array}{l}-0.02 \\
(0.04)\end{array}$ & $\begin{array}{l}-0.56^{*} \\
(0.31)\end{array}$ & 0.04 & & \\
\hline Sweden & $\begin{array}{c}0.32 * * * \\
(0.02)\end{array}$ & $\begin{array}{c}-0.67 * * * \\
(0.06)\end{array}$ & $\begin{array}{c}0.31 \\
(0.34)\end{array}$ & & 0.02 & \\
\hline Japan & $\begin{array}{c}-0.18 * * * \\
(0.02)\end{array}$ & $\begin{array}{c}-0.30 * * * \\
(0.05)\end{array}$ & $\begin{array}{c}0.18 \\
(0.18) \\
\end{array}$ & & & 0.02 \\
\hline U.S. & $\begin{array}{c}1.51^{* * *} \\
(0.01)\end{array}$ & $\begin{array}{c}0.09^{* * *} \\
(0.03)\end{array}$ & $\begin{array}{c}0.12^{* * *} \\
(0.02)\end{array}$ & 0.02 & & \\
\hline
\end{tabular}

Note: ***,** and * indicate the significant levels of $1 \%, 5 \%$ and $10 \%$ respectively.

Number of observations $=100$

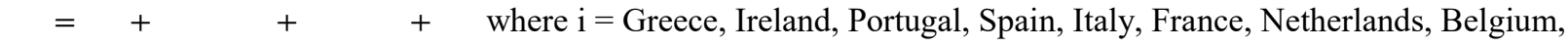
Switzerland, U.K., Sweden, Poland, Czech Republic and Hungary 
Figure 2: Dynamic Conditional Correlations from M-EGARCH Models (Daily Data, Static expectations) Greece-Ireland
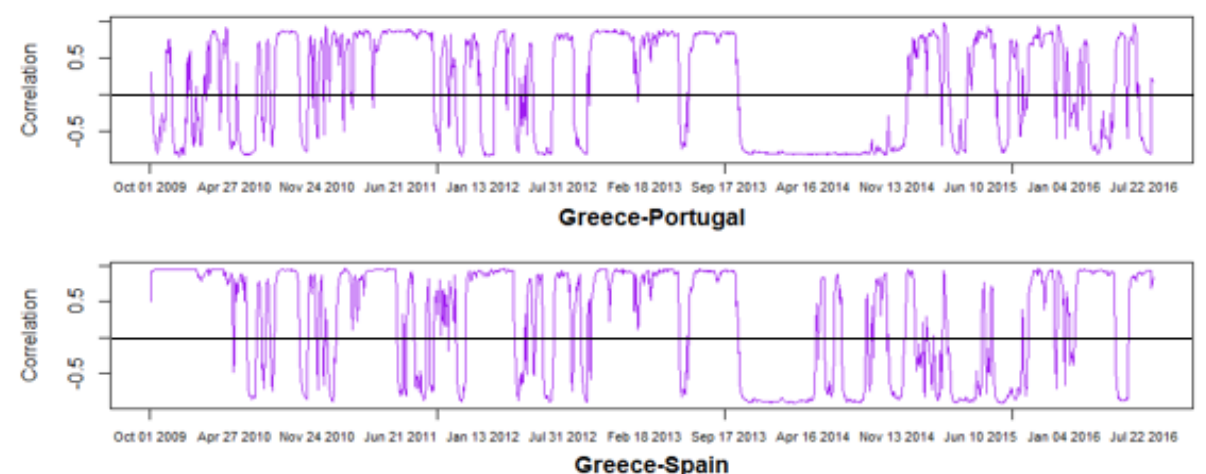
Greece-Spain
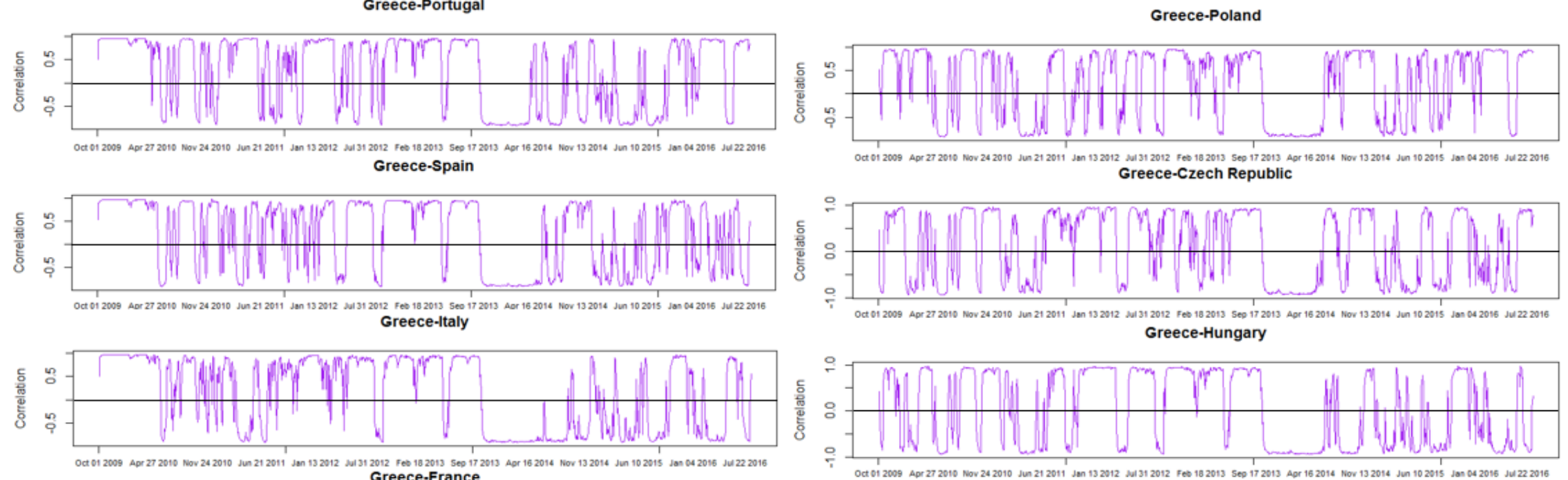

Greece-France
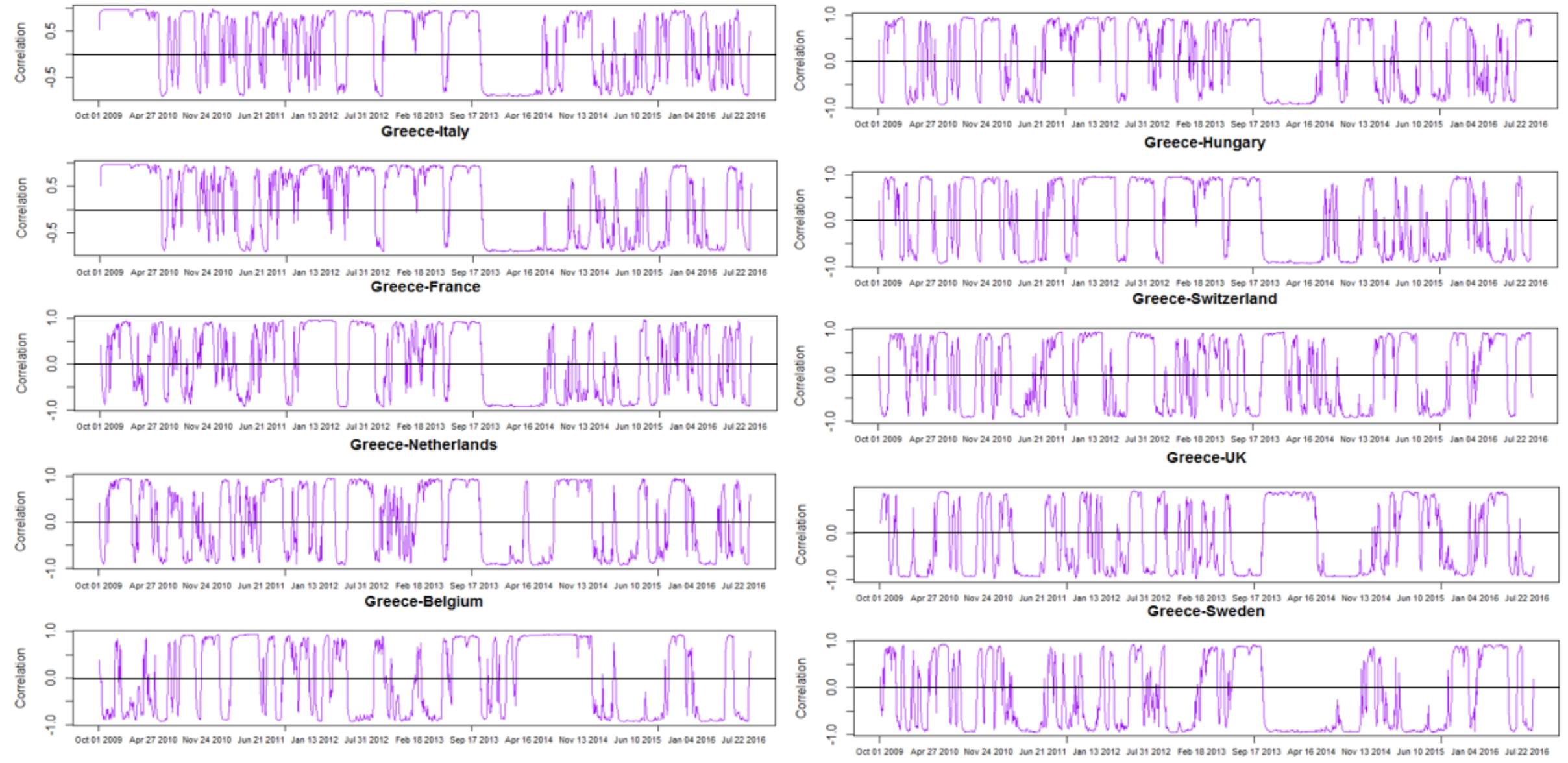


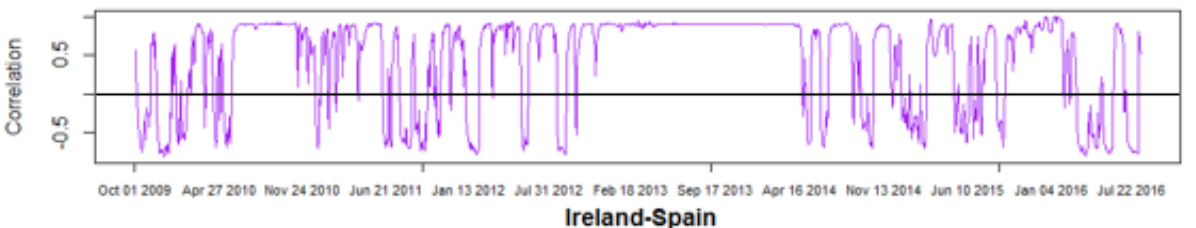

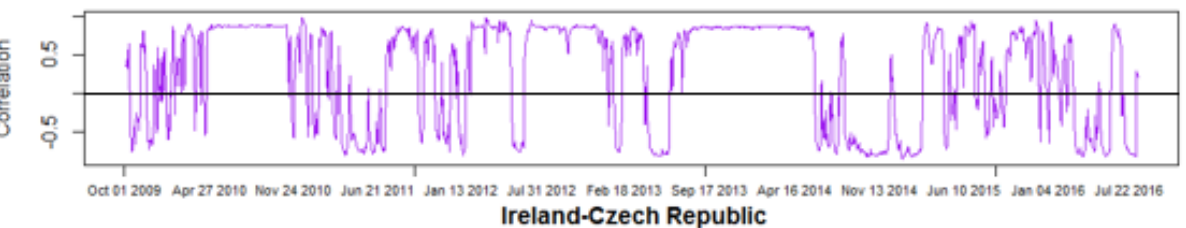
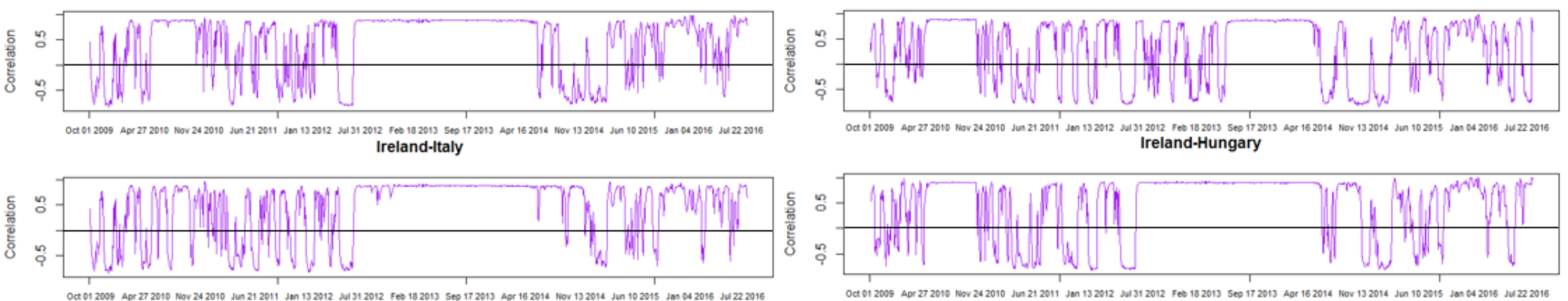
Ireland-Switzerland

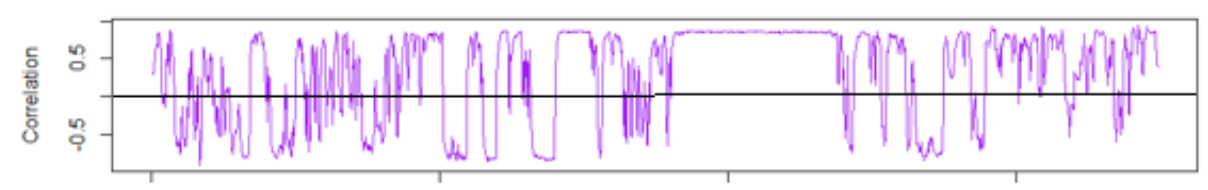
Ireland-Netherlands
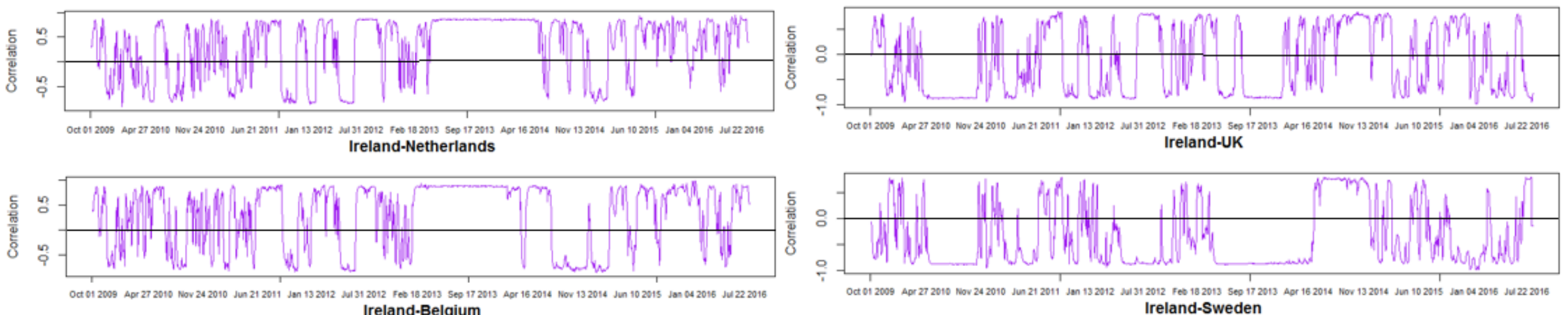

Ireland-Belgium

Ireland-Sweden
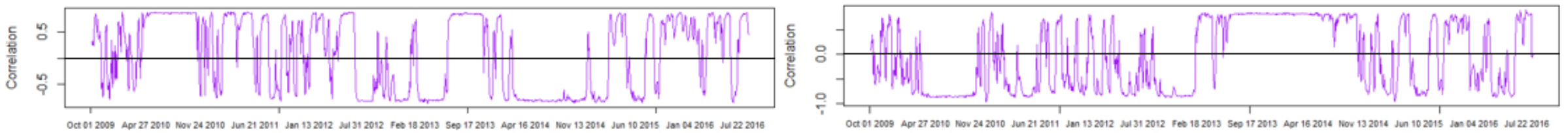


\section{Portugal-Spain}

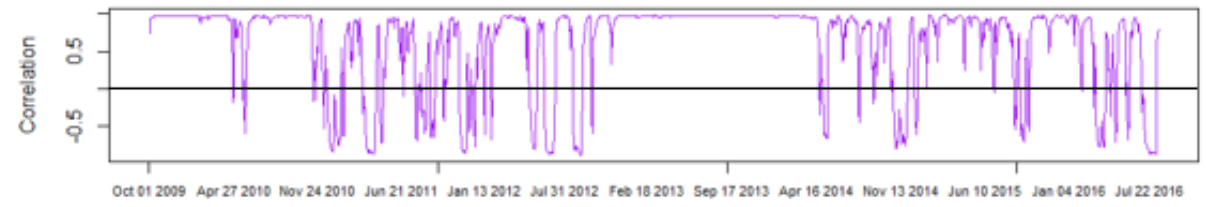

Portugal-Italy

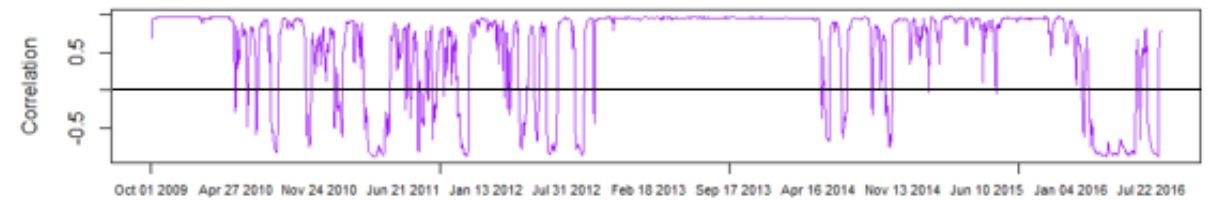

Portugal-France

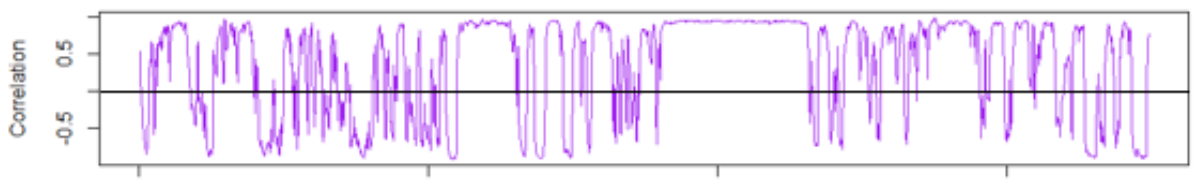

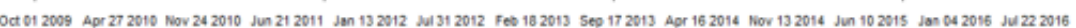
Portugal-Netherlands

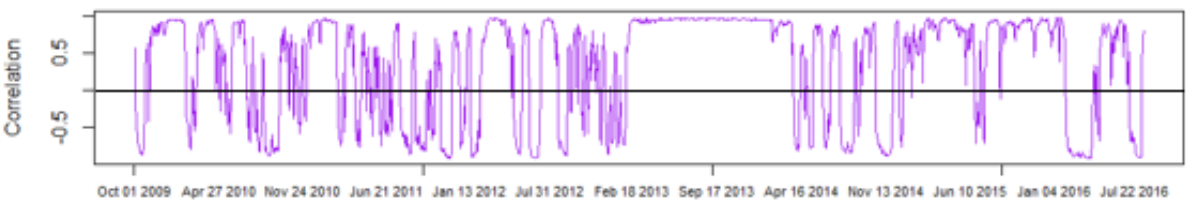

Portugal-Belgium

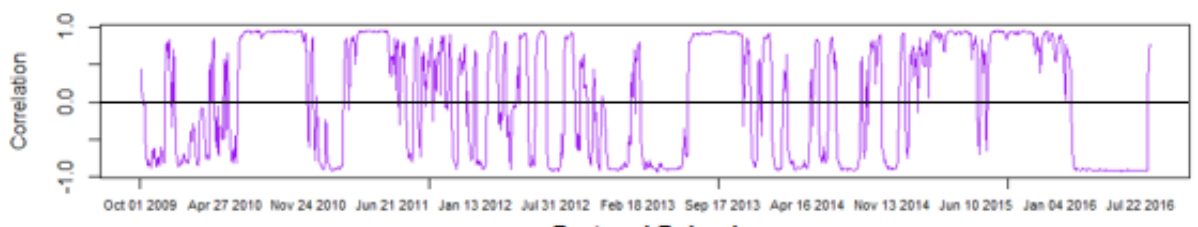

Portugal-Poland

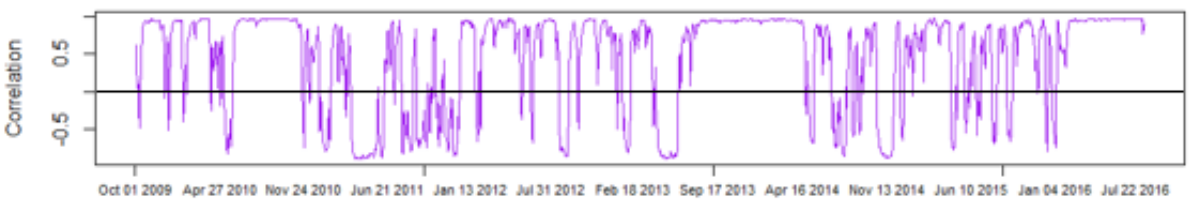

Portugal-Czech Republic

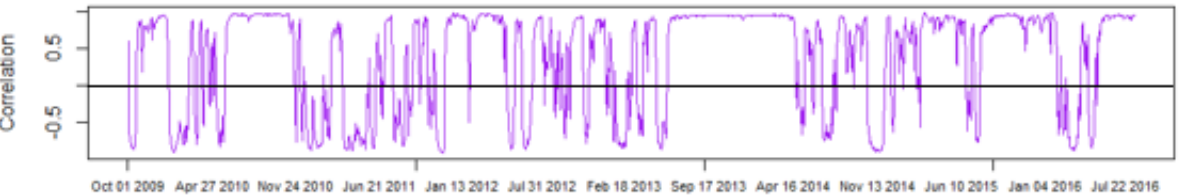

Portugal-Hungary

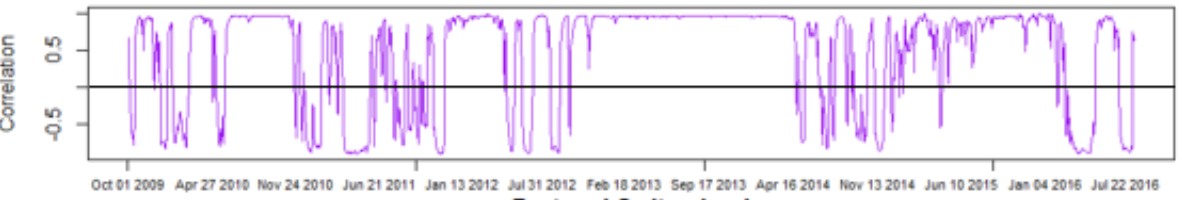

Portugal-Switzerland

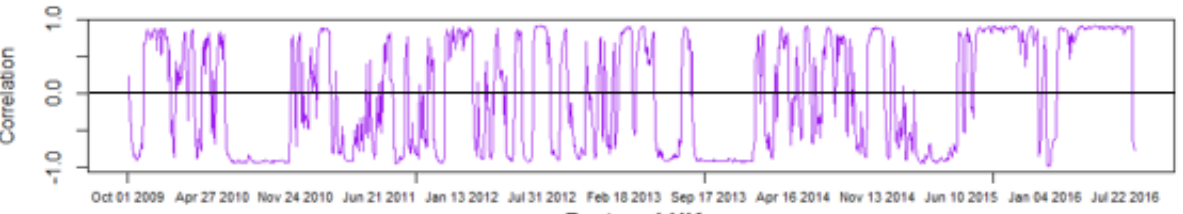

Portugal-UK

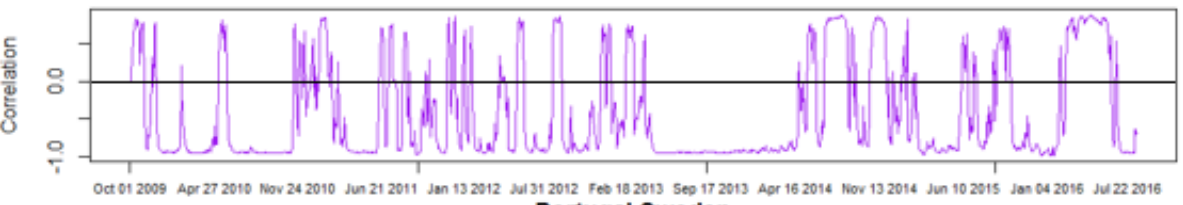

Portugal-Sweden

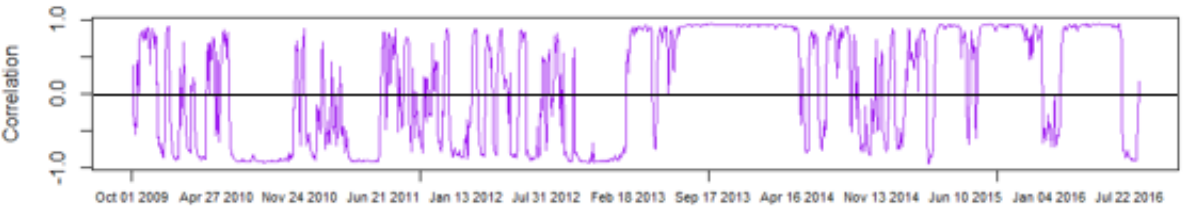


Spain-Italy

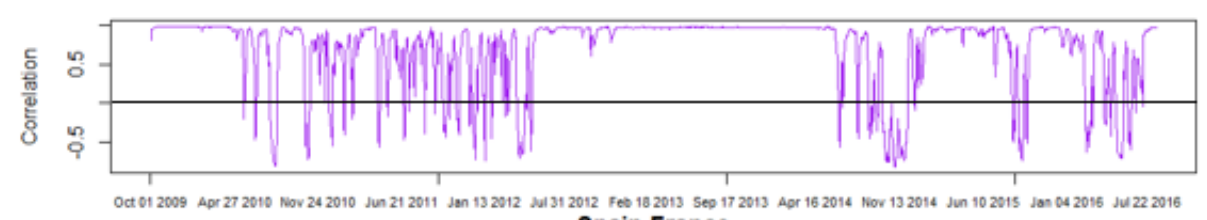
Spain-France

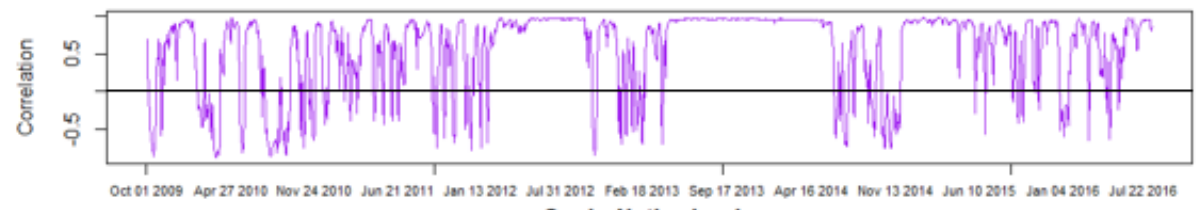
Spain-Netherlands

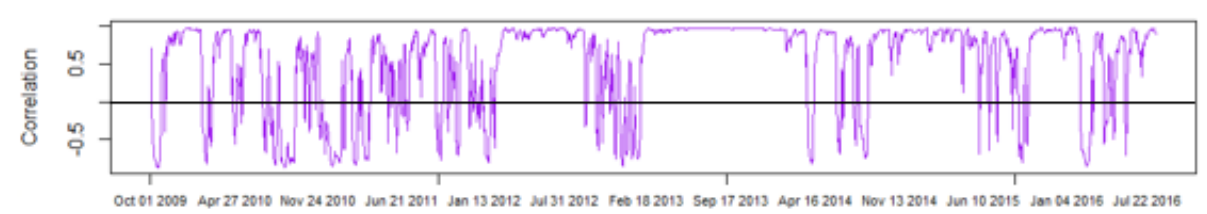
Spain-Belgium
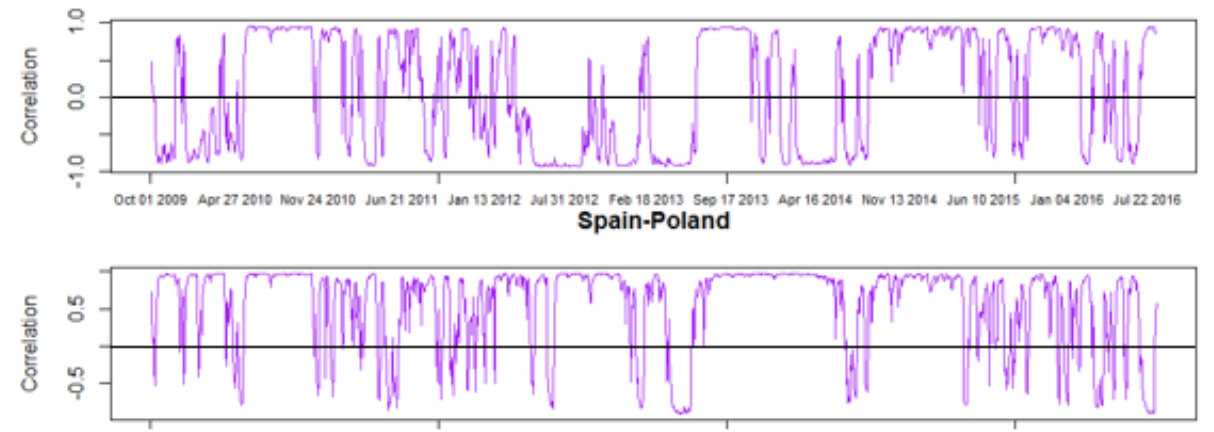

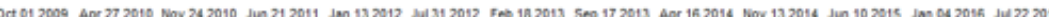

Spain-Czech Republic

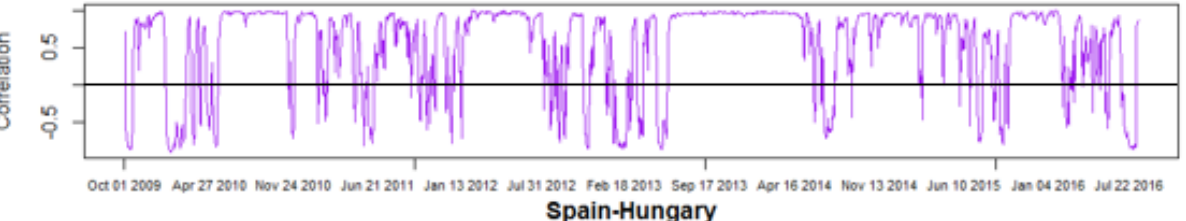

Spain-Hungary

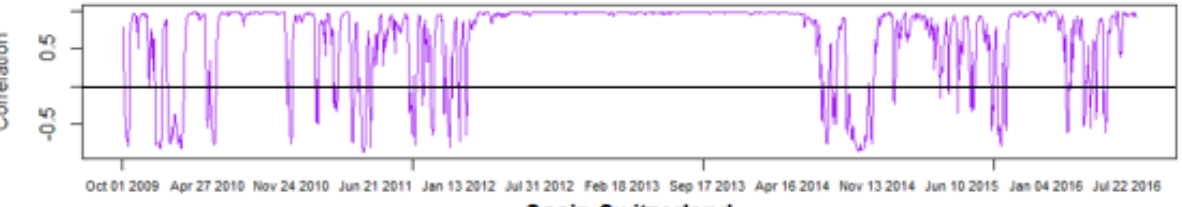

Spain-Switzerland
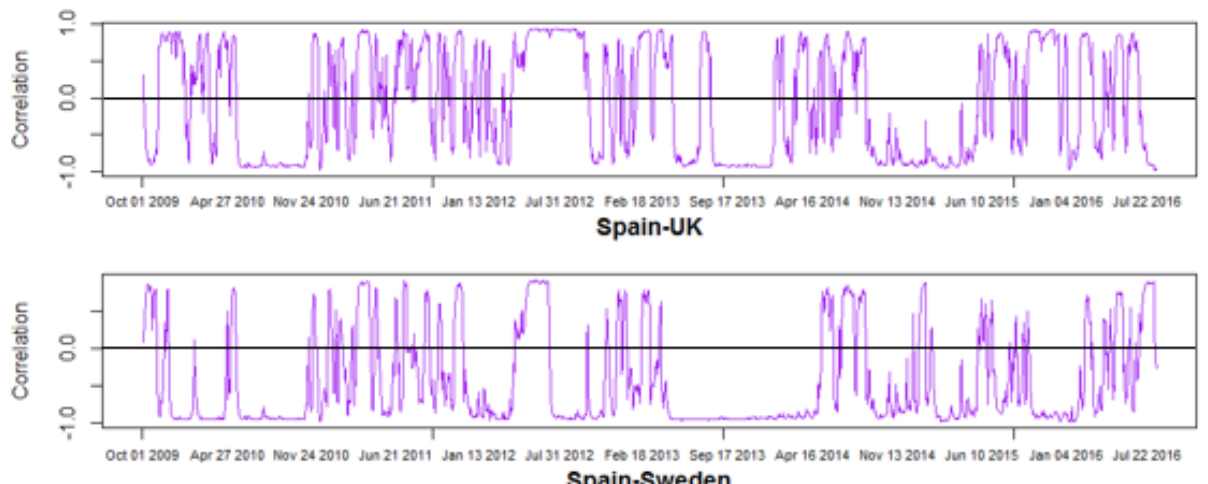

Spain-Sweden

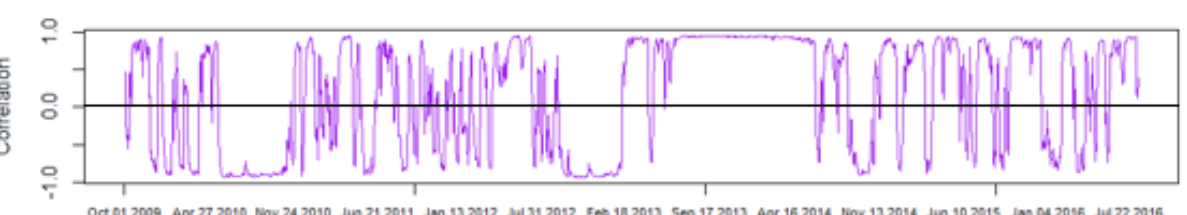




\section{Italy-France}

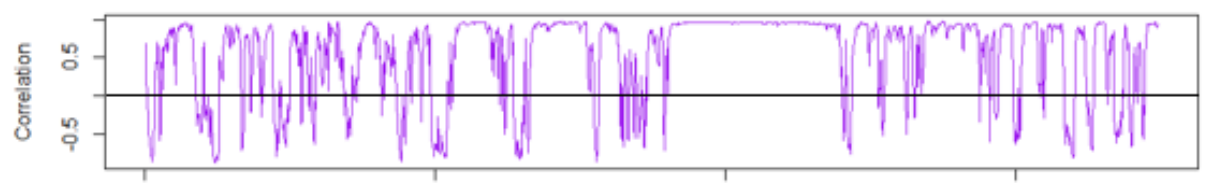

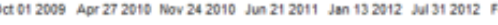

Italy-Netherlands

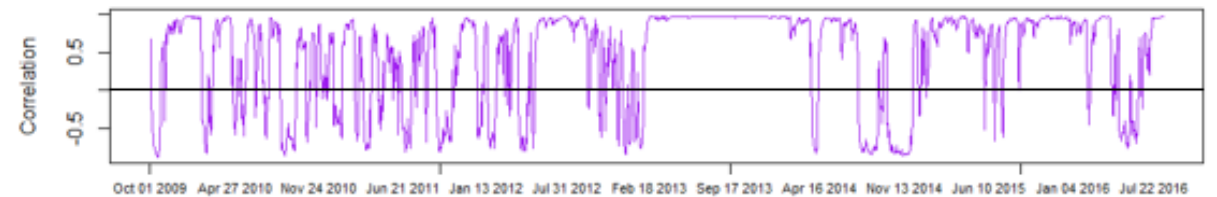

Italy-Belgium

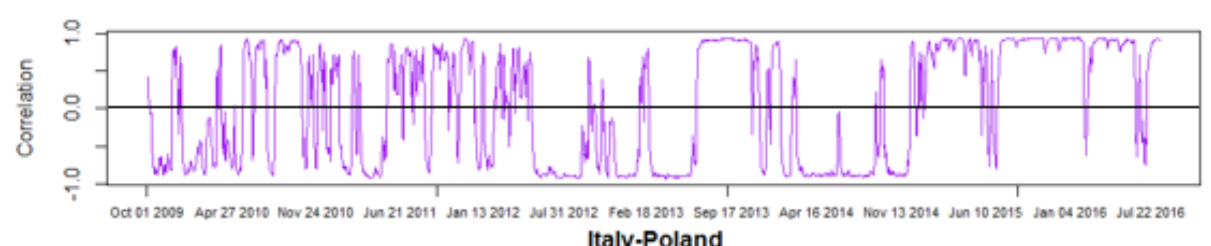

Italy-Poland

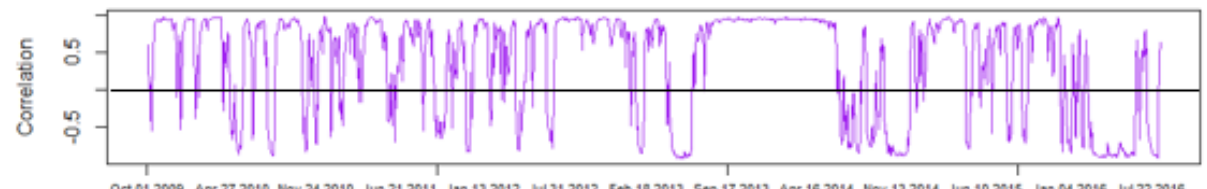

Italy-Czech Republic

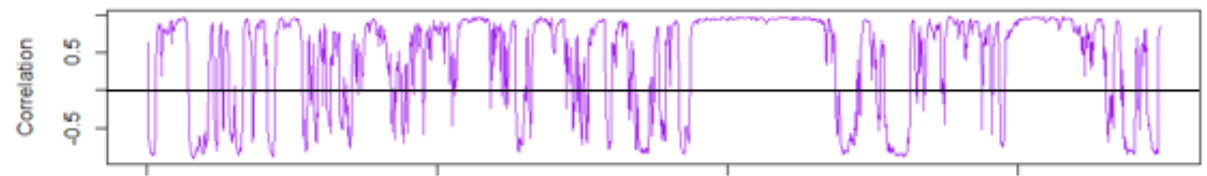

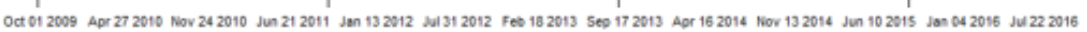

Italy-Hungary

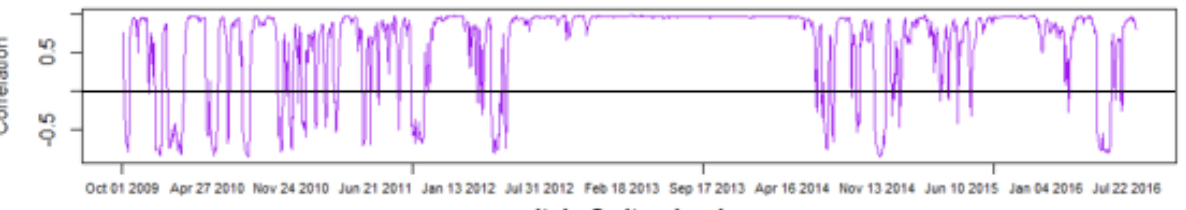

Italy-Switzerland

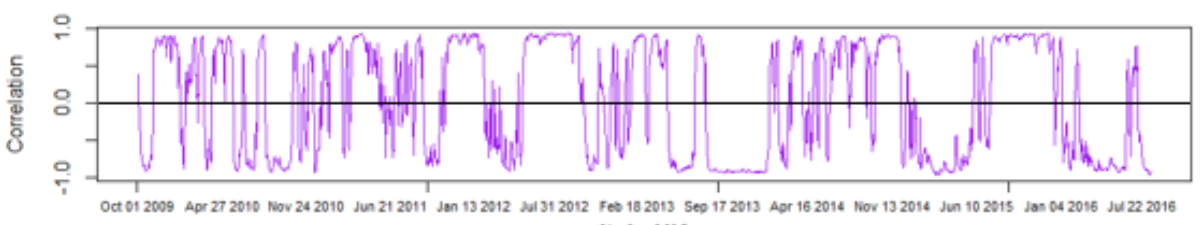

Italy-UK

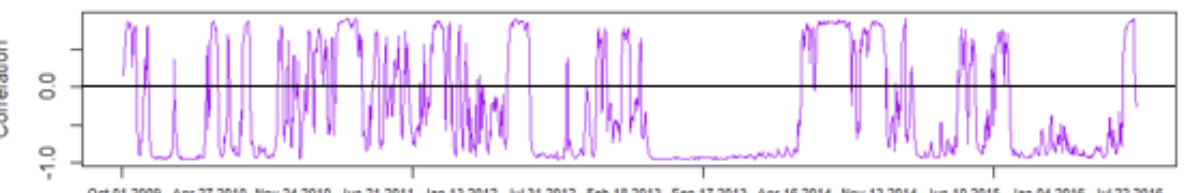

Italy-Sweden

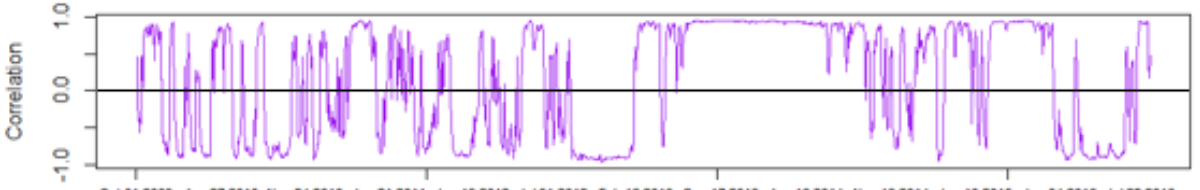


Figure 3: Dynamic Conditional Correlations from M-EGARCH Models (Weekly Data, Static expectations) Greece-Ireland

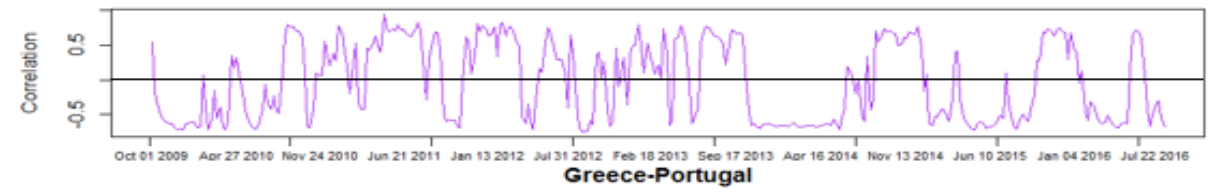

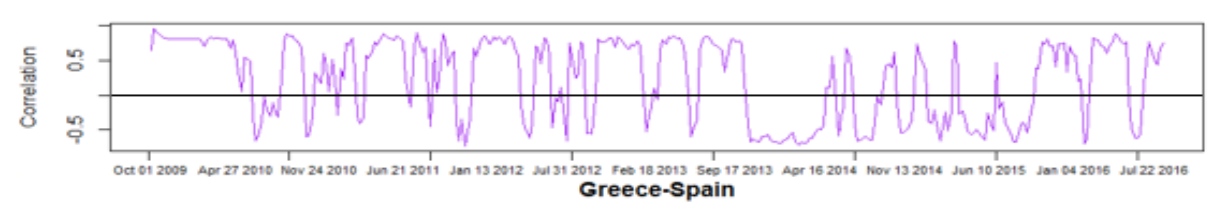

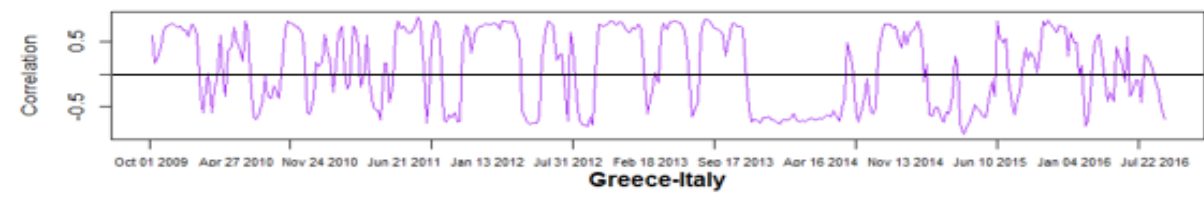

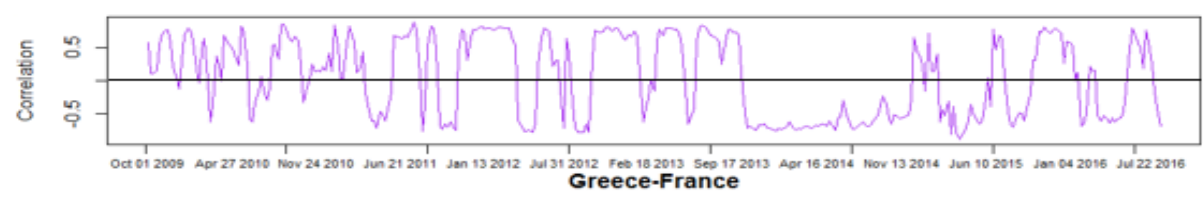

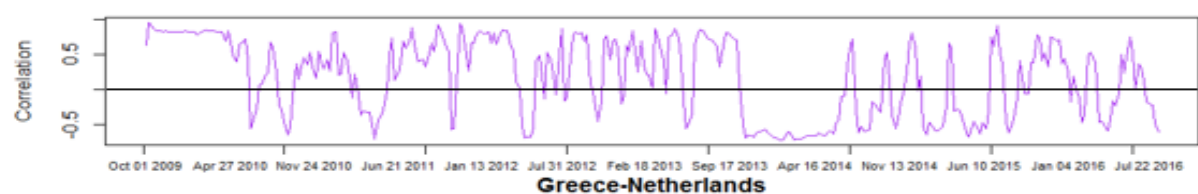
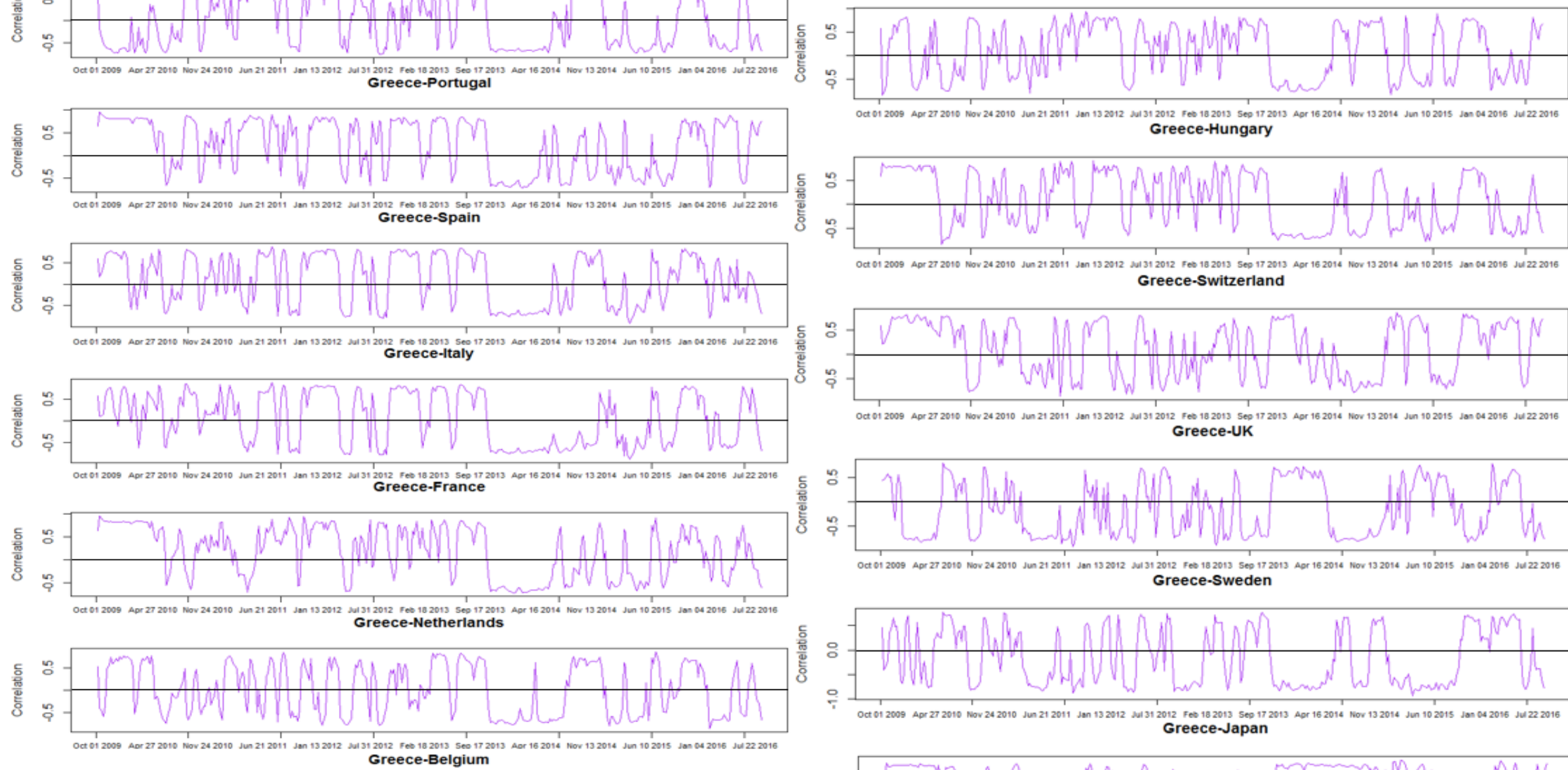

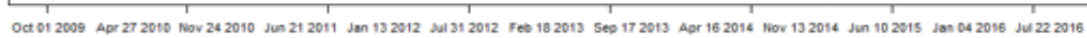
Greece-Hungary

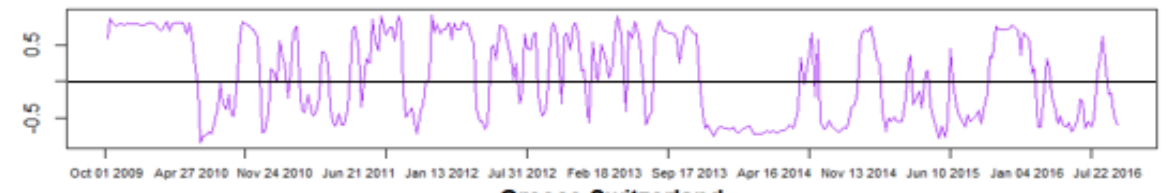
Greece-Switzerland

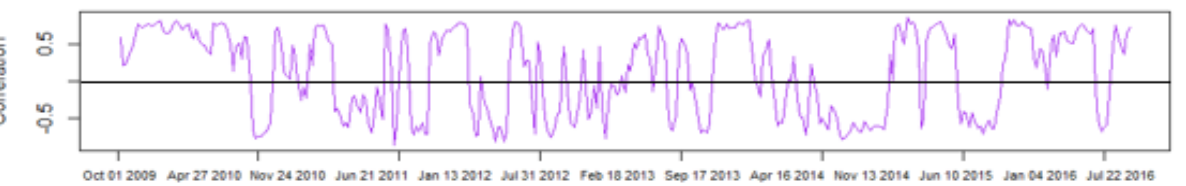
Greece-UK
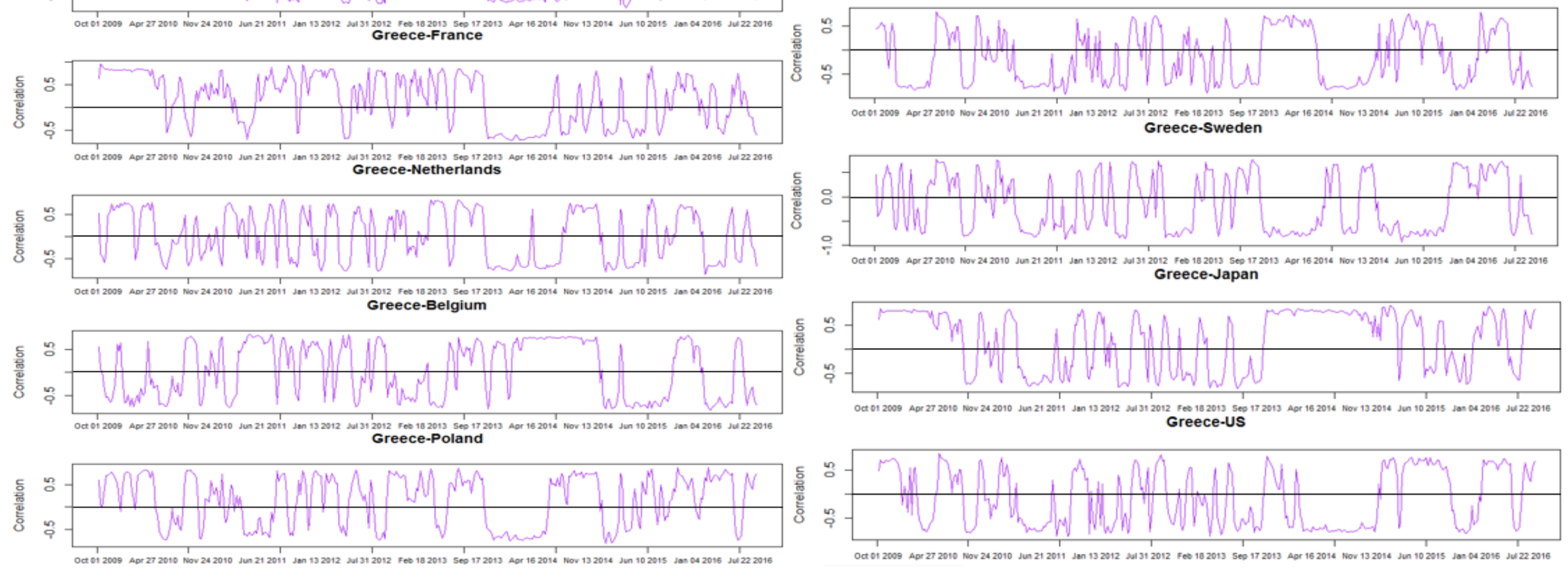


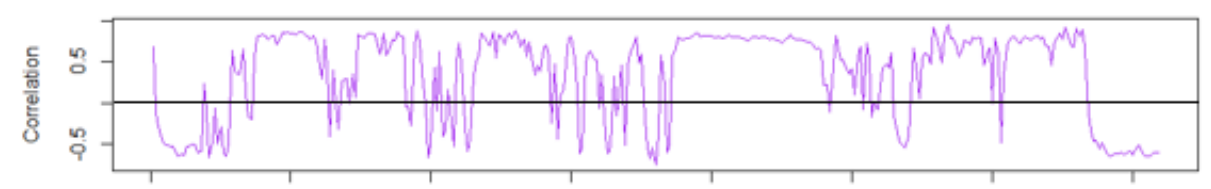

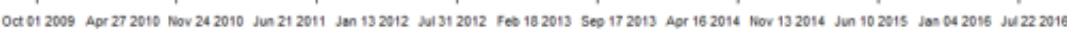
Ireland-Spain
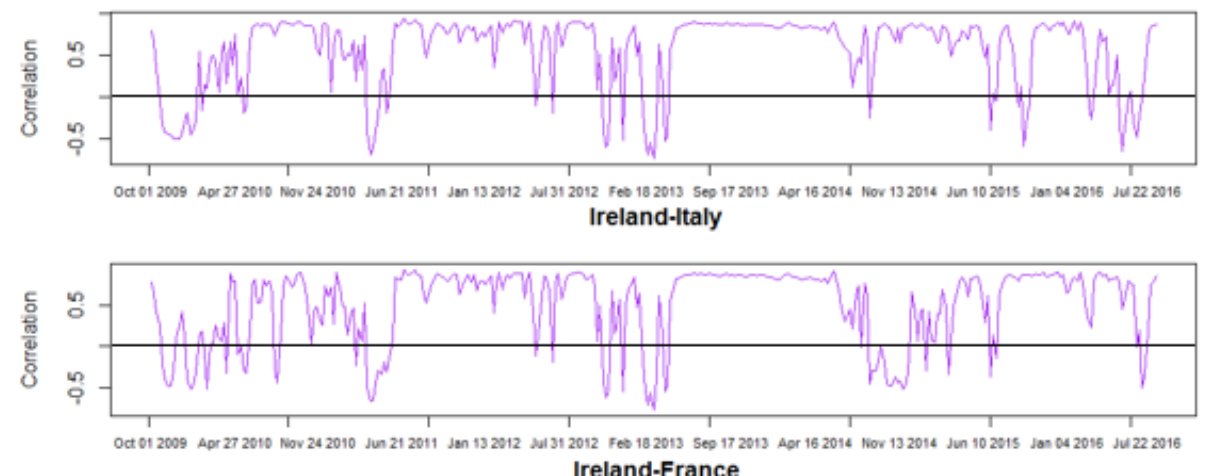
Ireland-France
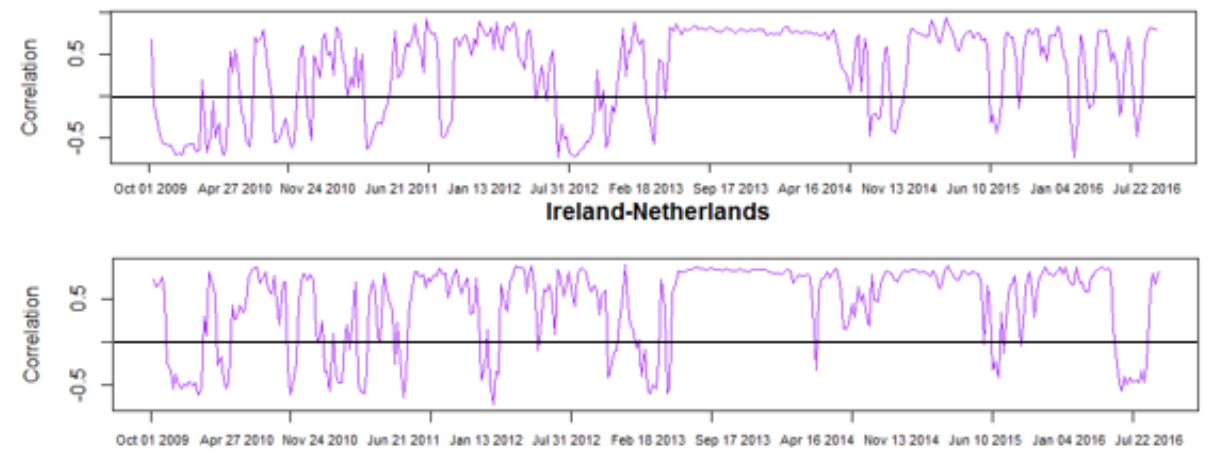
2012 Fet 182013 Sep 172017
Ireland-Belgium

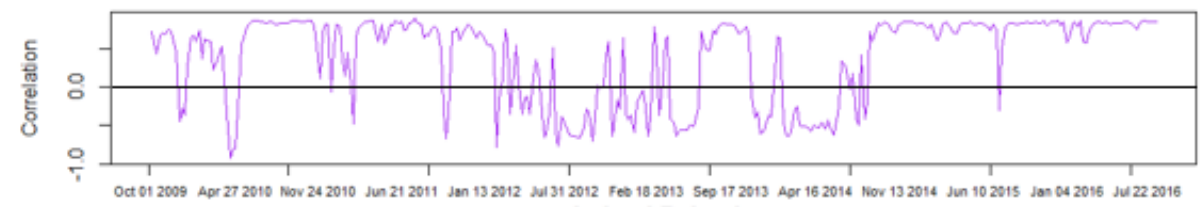
Ireland-Poland

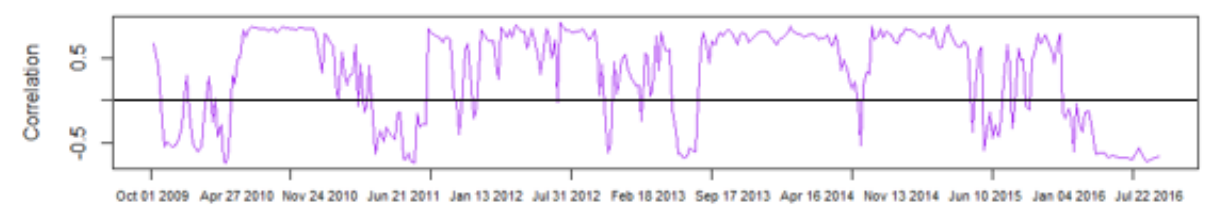

Ireland-Czech Republic

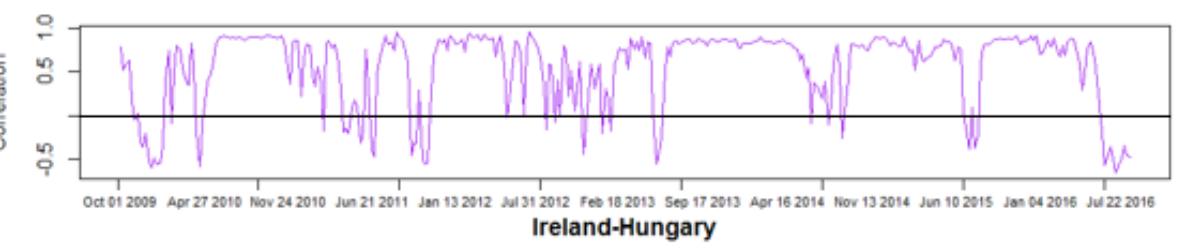
Ireland-Hungary

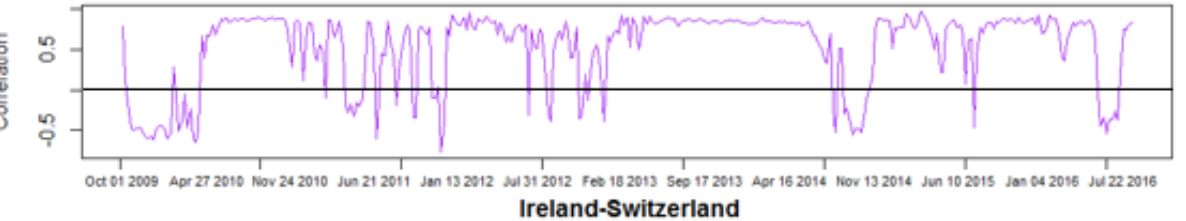
Ireland-Switzerland
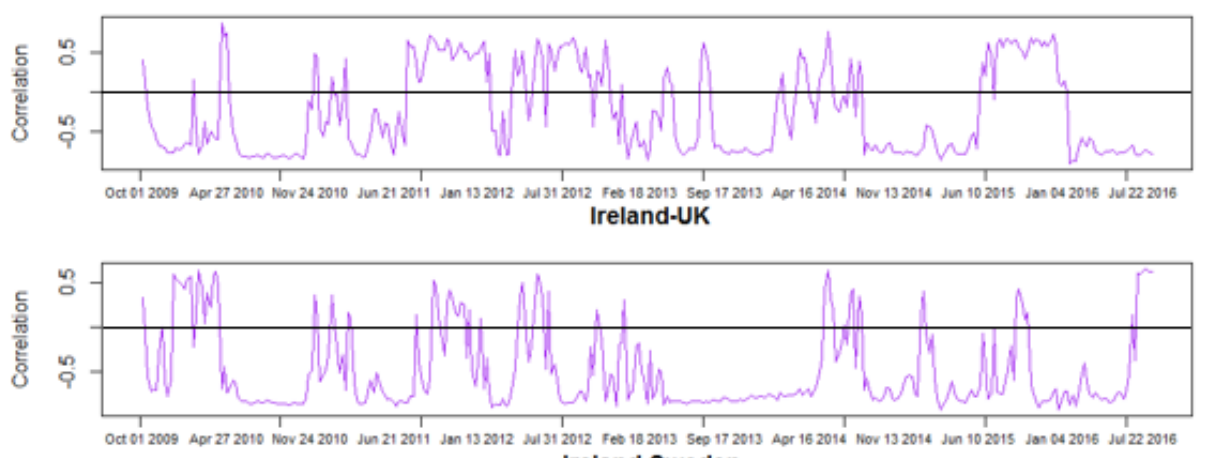
Ireland-Sweden

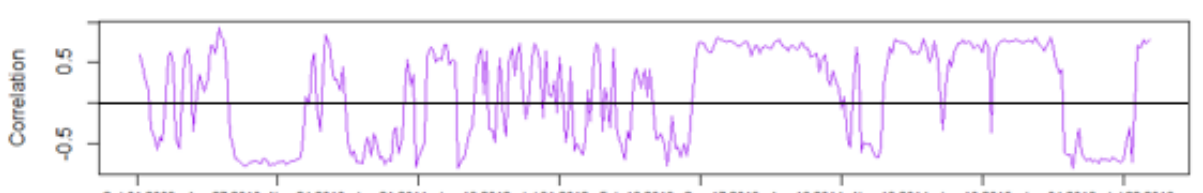

Ireland-Japan

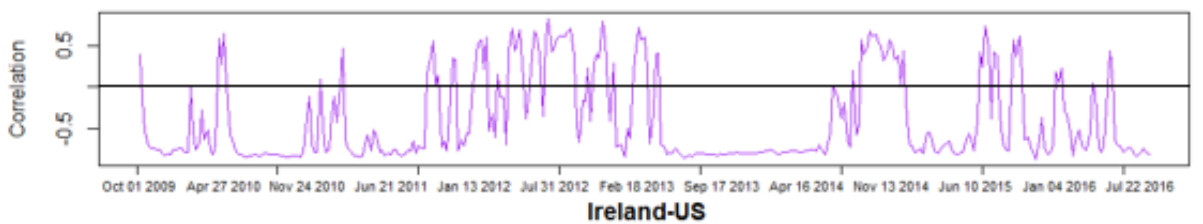

Ireland-US

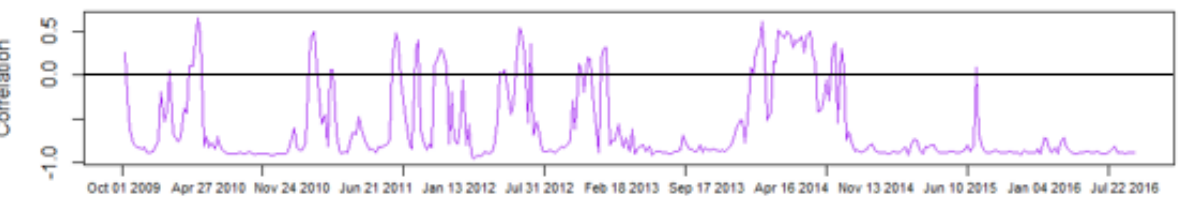




\section{Portugal-Spain}

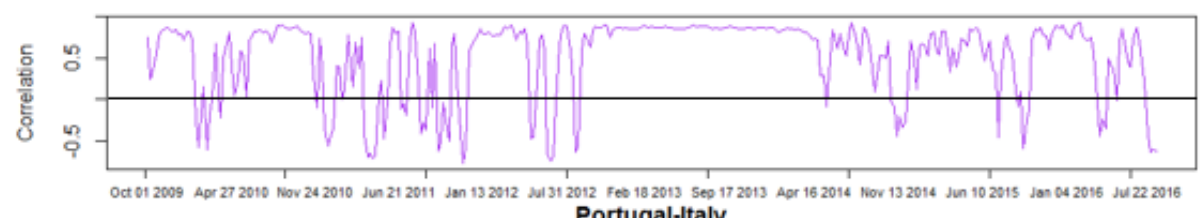

Portugal-Italy

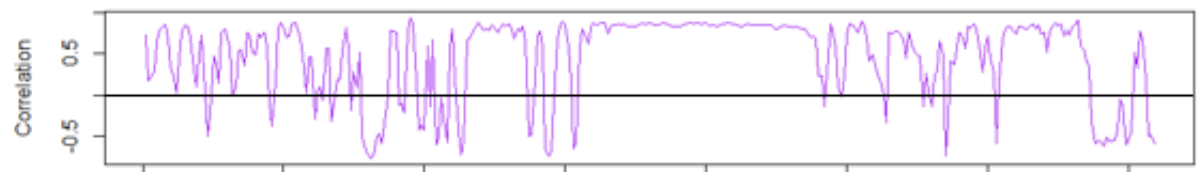

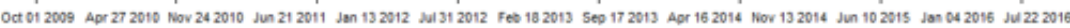
Portugal-France

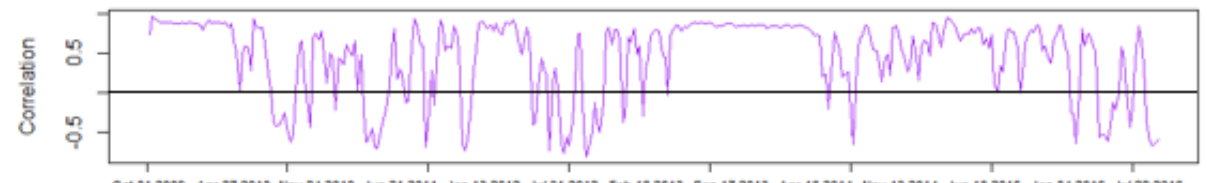

Portugal-Netherlands

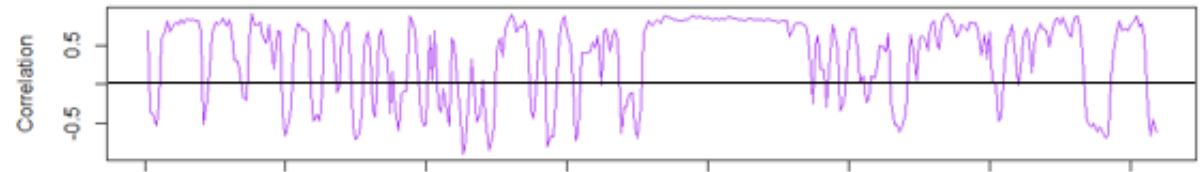
0
Pot Portugal-Belgium

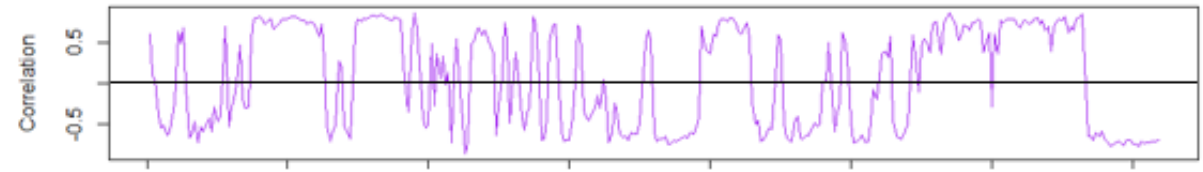

Portugal-Poland

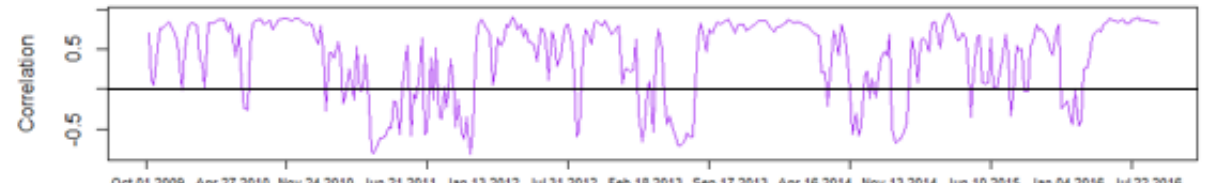

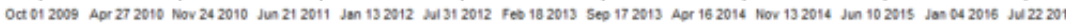

\section{Portugal-Czech Republic}

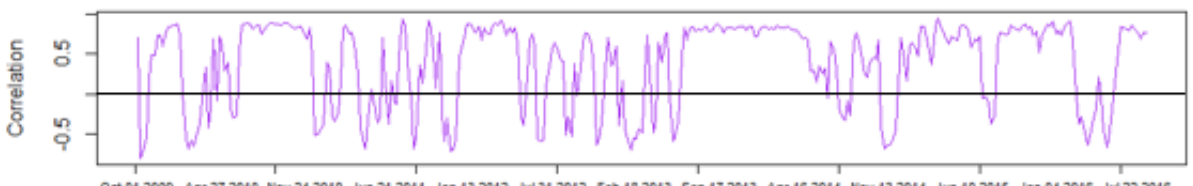

Portugal-Hungary

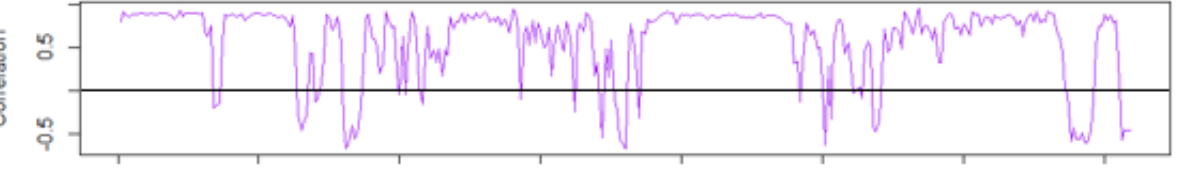

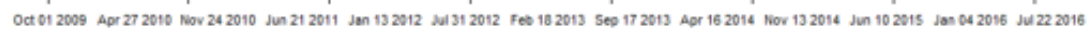
Portugal-Switzerland

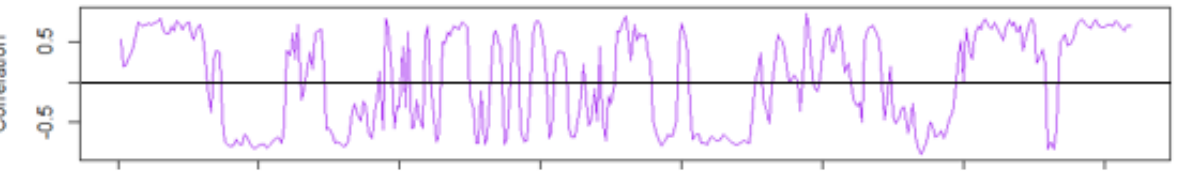

Portugal-UK

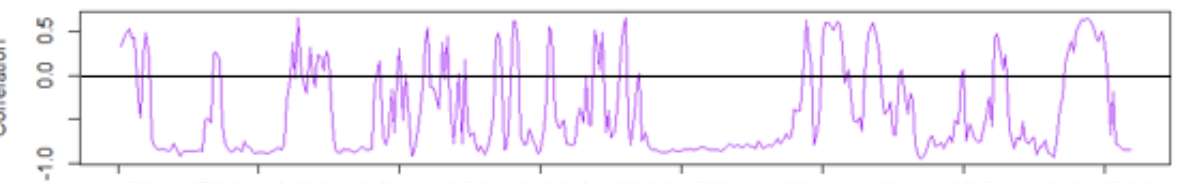

Portugal-Sweden

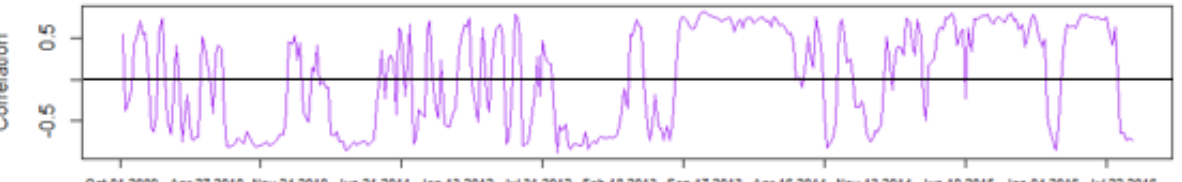

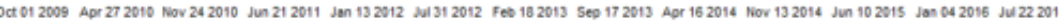

Portugal-Japan

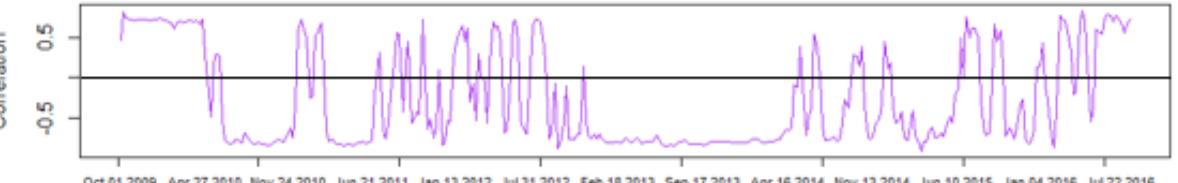

Portugal-US

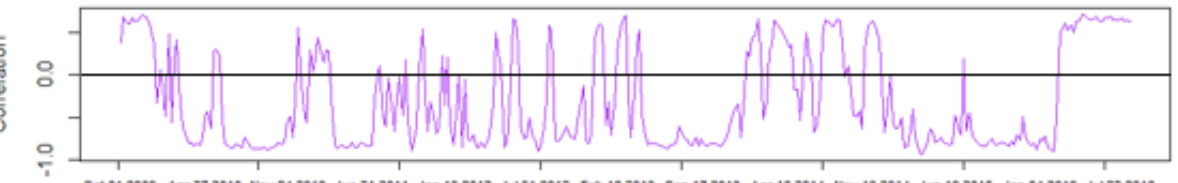


Spain-Italy

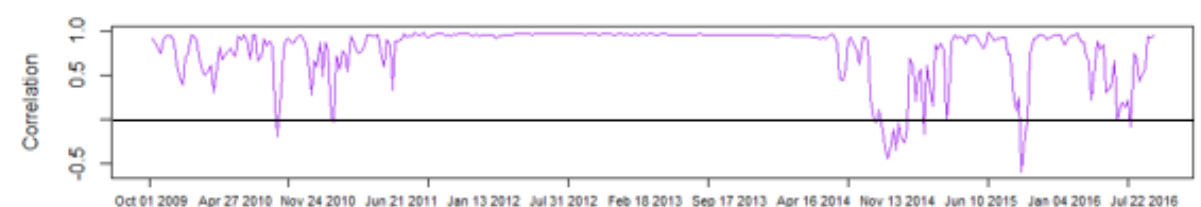

2012 Fet 182013 sep 18
Spain-France

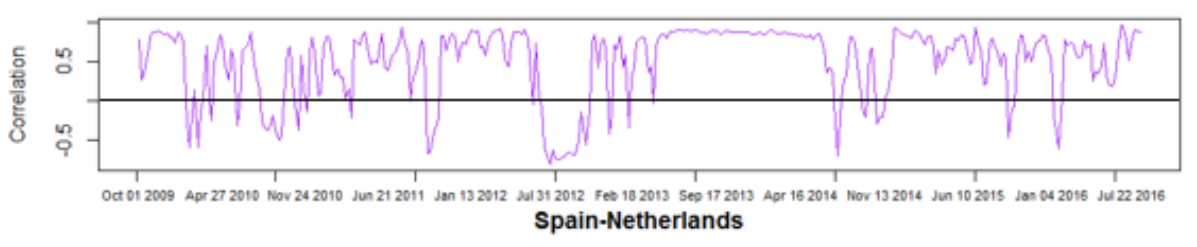
Spain-Netherlands

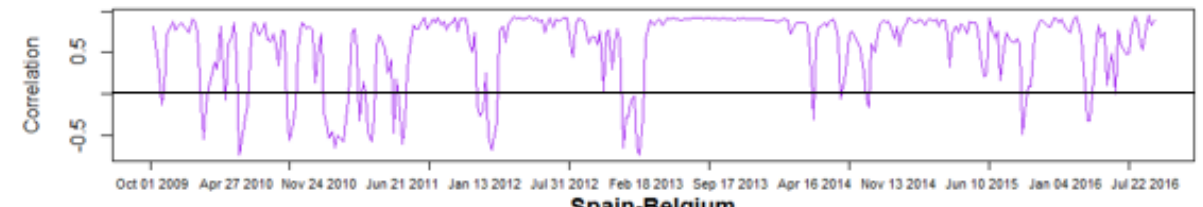

Spain-Belgium

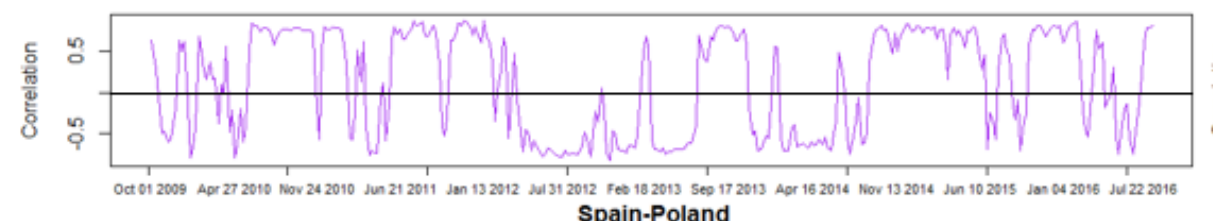

Spain-Poland

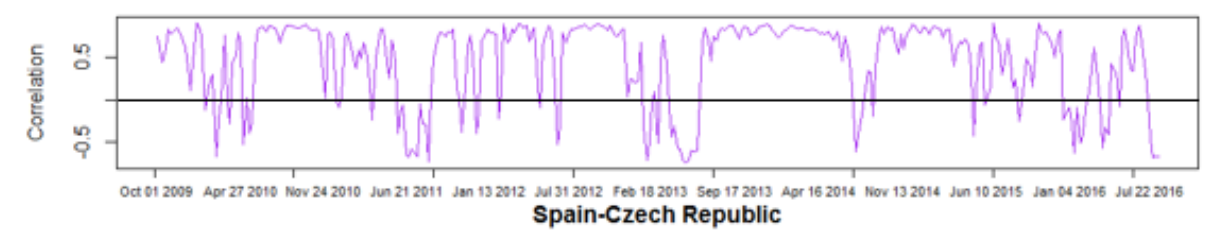

Spain-Czech Republic

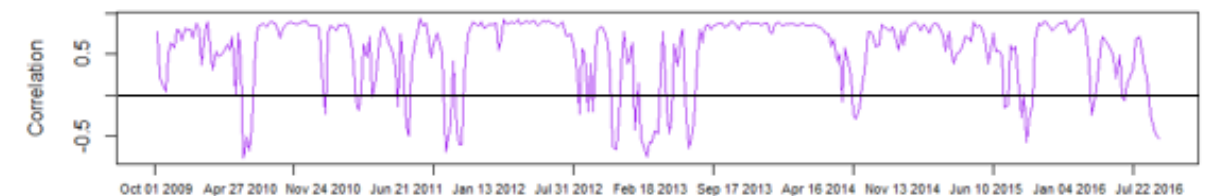

Spain-Hungary

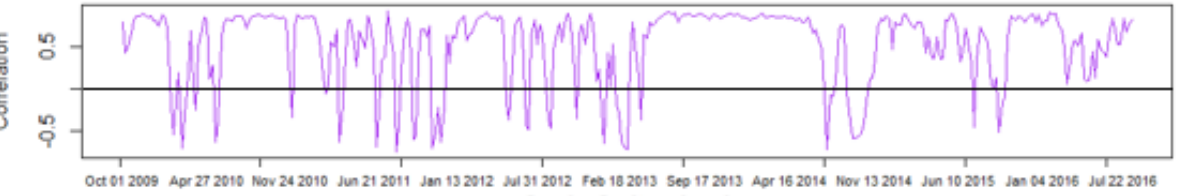

Spain-Switzerland
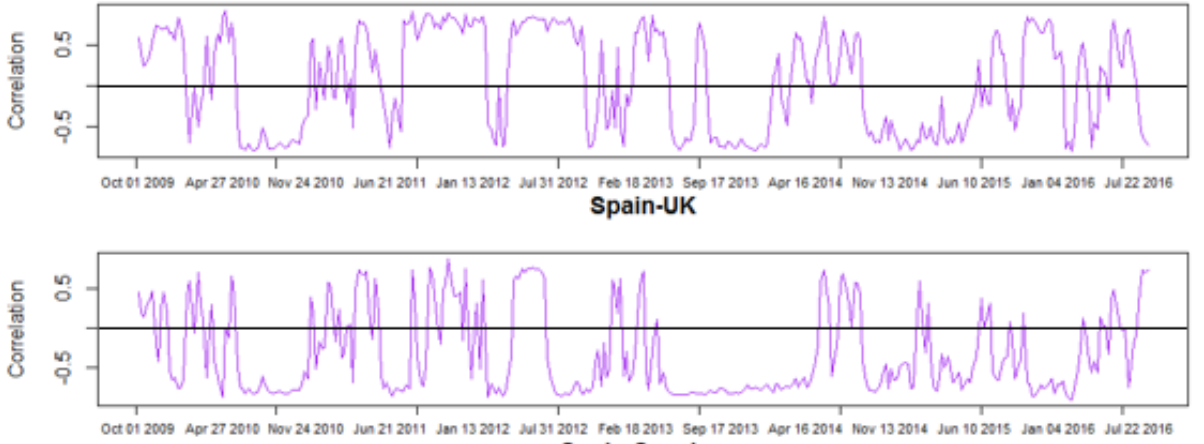

Spain-Sweden

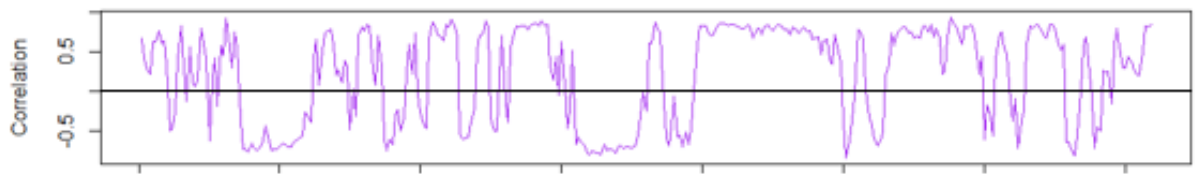

Spain-Japan
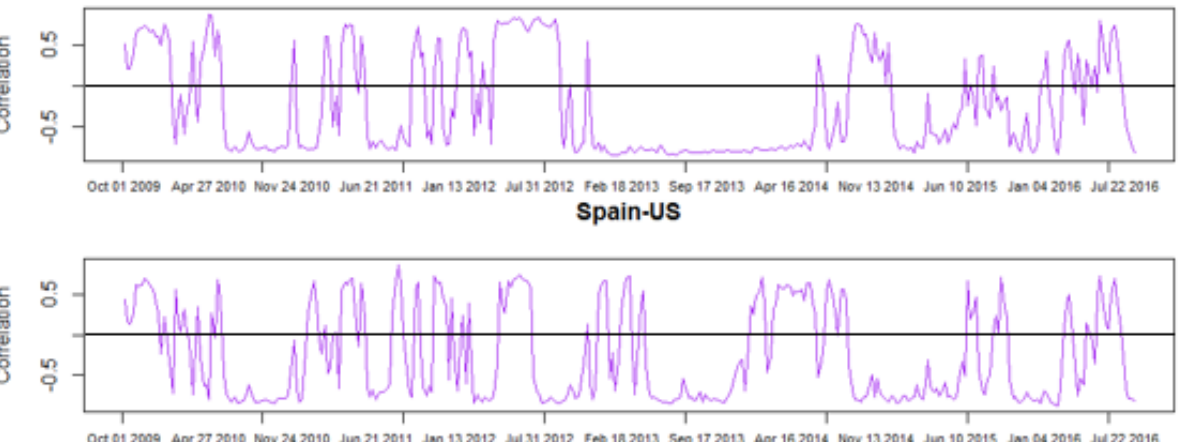
Italy-France

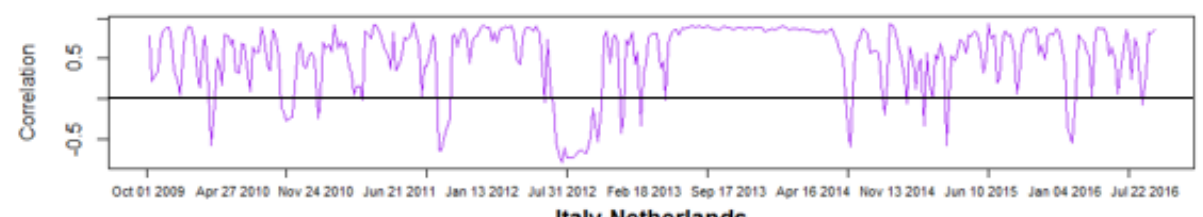
Italy-Netherlands

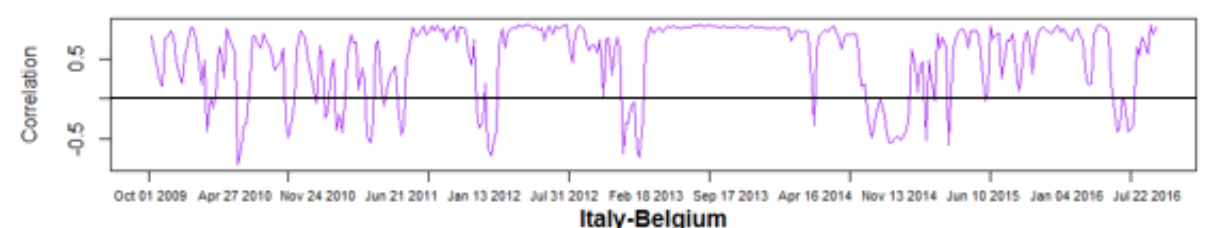
Italy-Belgium

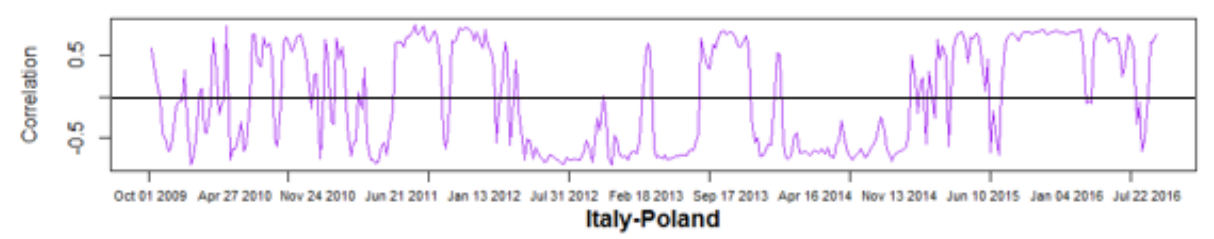

Italy-Poland

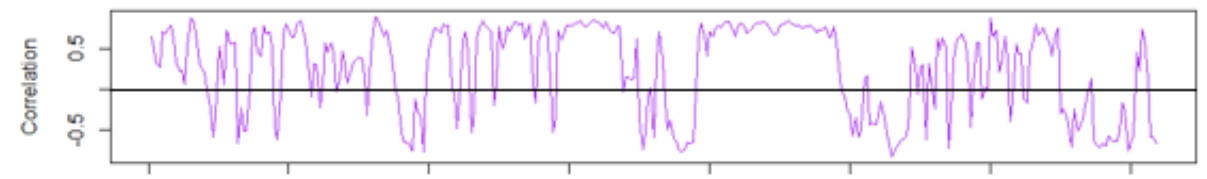

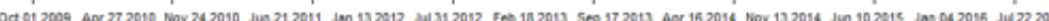
Italy-Czech Republic

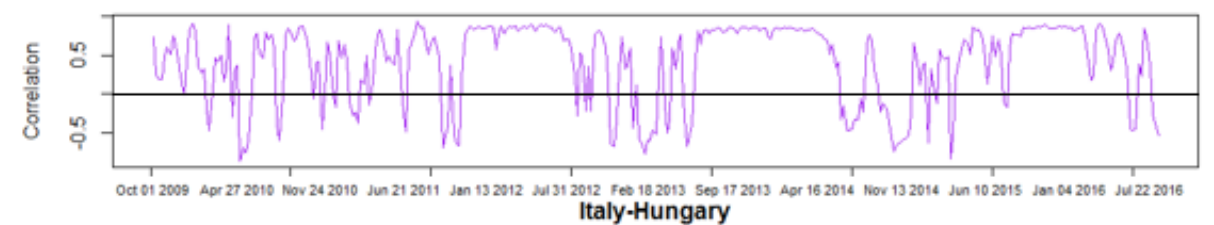

Italy-Hungary

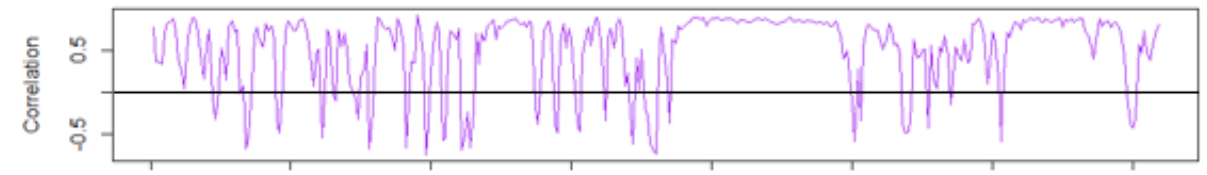

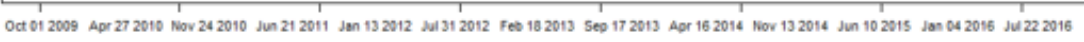

\section{Italy-Switzerland}

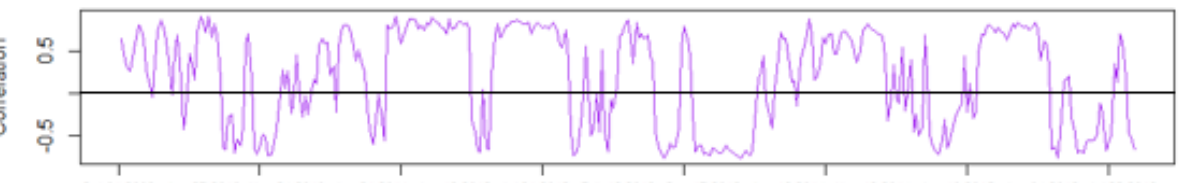

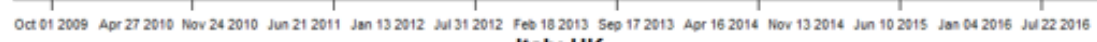
Italy-UK

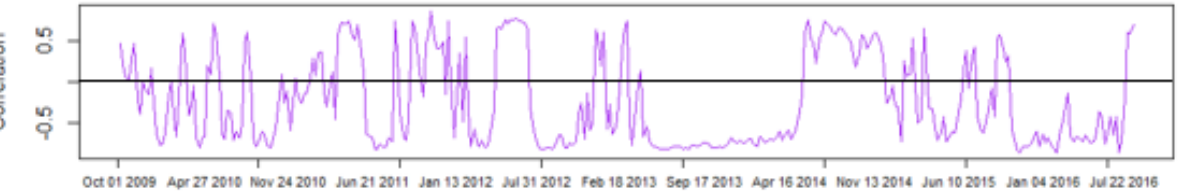

2012 Fes 182013 Sep 17
Italy-Sweden

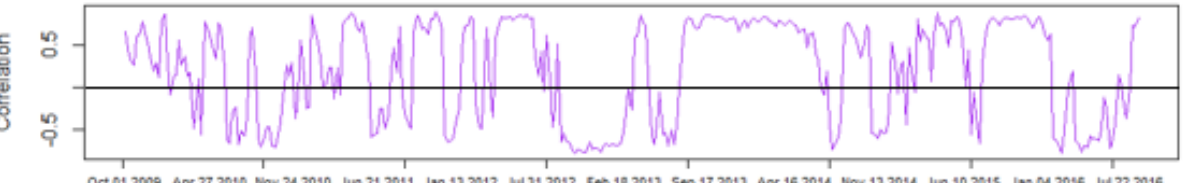

12 reo 182013 Sep
Italy-Japan

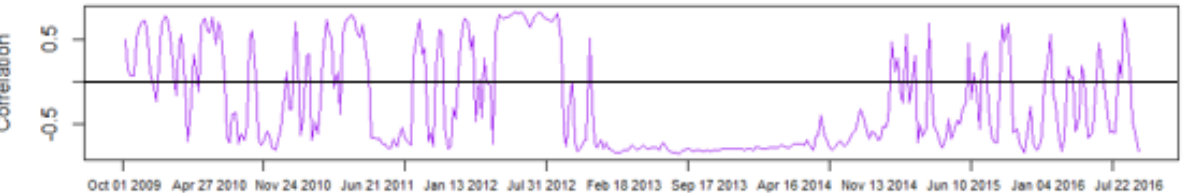
Italy-US

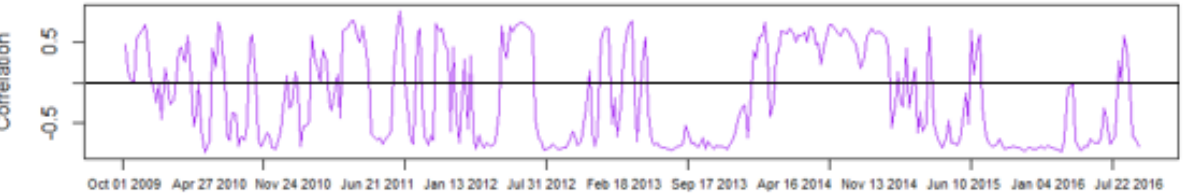

